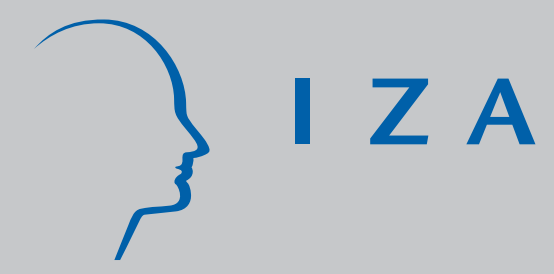

IZA DP No. 154

Microeconometric Evaluation of the Active Labour Market Policy in Switzerland

Michael Gerfin

Michael Lechner

May 2000 


\title{
Microeconometric Evaluation of the Active Labour Market Policy in Switzerland
}

\author{
Michael Gerfin \\ University of Bern, Department of Economics
}

Michael Lechner

University of St. Gallen, Swiss Institute for International Economics and Applied Economic Research (SIAW) and IZA, Bonn

\author{
Discussion Paper No. 154 \\ May 2000
}

\author{
IZA \\ P.O. Box 7240 \\ D-53072 Bonn \\ Germany \\ Tel.: +49-228-3894-0 \\ Fax: +49-228-3894-210 \\ Email: iza@iza.org
}

This Discussion Paper is issued within the framework of IZA's research area Project Evaluation. Any opinions expressed here are those of the author(s) and not those of the institute. Research disseminated by IZA may include views on policy, but the institute itself takes no institutional policy positions.

The Institute for the Study of Labor (IZA) in Bonn is a local and virtual international research center and a place of communication between science, politics and business. IZA is an independent, nonprofit limited liability company (Gesellschaft mit beschränkter Haftung) supported by the Deutsche Post AG. The center is associated with the University of Bonn and offers a stimulating research environment through its research networks, research support, and visitors and doctoral programs. IZA engages in (i) original and internationally competitive research in all fields of labor economics, (ii) development of policy concepts, and (iii) dissemination of research results and concepts to the interested public. The current research program deals with (1) mobility and flexibility of labor markets, (2) internationalization of labor markets and European integration, (3) the welfare state and labor markets, (4) labor markets in transition, (5) the future of work, (6) project evaluation and (7) general labor economics.

IZA Discussion Papers often represent preliminary work and are circulated to encourage discussion. Citation of such a paper should account for its provisional character. 


\title{
ABSTRACT \\ Microeconometric Evaluation of the Active Labour Market Policy in Switzerland*
}

In the second part of the 1990's Switzerland conducted an ambitious active labour market policy (ALMP) encompassing a wide variety of programmes. We evaluate the effects of these programmes on the individual employment probability of potential participants. Our econometric analysis uses unusually informative data originating from administrative unemployment and social security records. We apply a matching estimator adapted for the case of multiple programmes. We find substantial positive effects for one particular programme that is a unique feature of the Swiss ALMP. It consists of a wage subsidy for temporary jobs in the regular labour market that would otherwise not be taken up by the unemployed. We also find large negative effects for traditional employment programmes operated in sheltered labour markets. For training courses the results are mixed.

JEL Classification: J64, J68, H43, C14, C40

Keywords: Unemployment, Swiss labour market, evaluation of multiple programmes, treatment effects, balancing score, matching

\author{
Michael Lechner \\ Swiss Institute for International Economics and \\ Applied Economic Research (SIAW) \\ University of St. Gallen \\ Dufourstr. 48 \\ $\mathrm{CH}-9000$ St. Gallen, Switzerland \\ Tel.:+41-071-224 28 14, Sec.: - 2350 \\ Fax:+41-071- 2242298 \\ Email: Michael.Lechner@unisg.ch
}

\footnotetext{
*We are grateful to the State Secretariat of Economic (seco) Affairs of the Swiss Government and the Bundesamt für Sozialversicherung for providing the data. Financial support from the Swiss National Science Foundation (12-50815.97, Gerfin, and 12-53735.18, Lechner) as well as from seco is gratefully acknowledged. Heidi Steiger provided valuable research assistance. Monica Curti and Jonathan Gast, both seco, were also particularly helpful for many practical details of this study. A preliminary version of this paper has been presented at the annual meeting of the section on population economics of the German Economic Association in Zurich, 2000, as well as at a seminar at IZA in Bonn, at Texas A\&M, Rice University, the University of Chicago, the University of California at Los Angeles (UCLA), and the University of Western Ontario (London). We thank participants, in particular Jim Heckman, Guido Imbens, Jeff Smith, and Todd Stinebricker, for helpful comments and suggestions.

All remaining errors are our own.
} 


\section{Introduction}

In the 1990s substantial active labour market policies (ALMP) were enacted in many continental European countries. Many policy makers as well as economists considered ALMP as the most important set of measures to bring Europe's notoriously high levels of unemployment back to some sort of socially acceptable level, without having to go through the painful side effects of substantial adjustments of the labour markets. In other words, expenditures of ALMP promised to save the continental European model of a market economy as compared to the Anglo-Saxon model, which is seen to have implications for working individuals not acceptable to a majority of the European public. Recent evaluation studies surveyed for example by Fay (1996) and Heckman, LaLonde, and Smith (1999) however do not appear to develop any consensus whether these hopes are justified. Quite to the contrary, many of studies raise serious doubts. The available data used in many of these studies were far from ideal so that there is an additional uncertainty what the 'true' effect of Europe's diverse ALMP might be.

Switzerland looked and still looks like an oasis within Western Europe in terms of unemployment that remained between almost $0 \%$ and $5 \%$ in the 1990s. The Swiss labour market operates on broadly similar terms as for example the German labour market. It is even more geared towards consensus between union, employers and government. However, the side effects of globalisation are also much more severe in the small and fairly open economy of Switzerland that entertains comparatively high labour costs.

After Switzerland experienced a continuous increase in unemployment in the beginning of the decade, a revision of the law regulating unemployment insurance and ALMP was enacted in 1997. One of the innovations of the revision consists in making benefit payments conditional on participation in a labour market programme after being unemployed for more than seven months. This "activation concept" (OECD, 1996) is a specific feature of the Swiss system, although in practice it is not strictly enforced. The Swiss ALMP is heterogeneous and consists of many different training and employment programmes that are similar to the kind of programmes that can be found in other European countries as well. In addition, there is a fairly unique large programme that we will call TEMPORARY WAGE SUBSIDY. ${ }^{1}$ It encourages unemployed to accept

\footnotetext{
1 Somewhat strangely, this programme is officially not part of the ALMP.
} 
offers for strictly temporary jobs that pay less than their unemployment benefit by (over-) compensating the difference with a subsidy.

We perform a microeconometric evaluation of the different programmes of the Swiss ALMP, including TEMPORARY WAGE SUBSIDY. We focus on the differences of individual success in the labour market that are due to these programmes. The Swiss government made available a novel and very informative and large data base consisting of administrative records from the unemployment insurance system as well as from the social security system for the population of unemployed persons in December 1997. ${ }^{2}$ We claim that in this data we observe all major factors that jointly influence both the selection into the various programmes as well as the outcomes on the labour market.

For any evaluation study there is the question of what kind of identification strategies and estimation method should be used to obtain reliable results for the specific situation. Angrist and Krueger (1999), Heckman and Robb (1986), and Heckman, LaLonde, and Smith (1999) provide an excellent overview of available identification and estimation strategies. Because we believe that we observe the major facts influencing selection as well as outcomes, we impose the assumption that labour market outcomes and selection are independent conditional on these observables (conditional independence assumption, CIA). Therefore, for the present situation characterised by rich data an estimator that uses CIA and hence avoids almost any other assumption would be called for. In addition, that estimator should avoid restricting the effects to be same in specific subpopulation because there is substantial a priori evidence that those programmes could have very different effects for different individuals. Finally, this estimator has to take account of the very different programmes that make up the Swiss ALMP.

The estimator that fulfils these requirements to a large extent is the so-called matching estimator. The idea of matching is to construct an artificial comparison group and compare the labour market outcomes of this group to those of the group of programme participants. Under CIA, this estimator is consistent when the comparison group has the same distribution of observable factors determining labour market outcomes and participation as the group in the programme. Matching has recently been discussed and applied in the literature to various evaluation problems by Angrist (1998), Dehejia and Wahba (1999), Heckman, Ichimura, and Todd (1998), Heckman,

\footnotetext{
2 This study is part of a series of evaluation studies commissioned by the Swiss State Secretariat of Economic Affairs (seco), that use however very diverse empirical methods (for an overview in German see http://www.secoadmin.ch/wirtpol/amp/d_ForschungALV.html).
} 
Ichimura, Smith, and Todd (1998), and Lechner (1999b, 2000a), among others. Recently the standard matching approach that considers only two states (in the programme vs. not in the programme) has been extended by Imbens (1999) and Lechner (1999a) to allow for multiple programmes.

Our results indicate considerable heterogeneity both with respect to the effects of the different programmes as well as with respect to the effects for different subpopulations within a given programme. In the Swiss case it appears that EMPLOYMENT PROGRAMMES perform very poorly, VOCATIONAL TRAINING PROGRAMMES show a rather mixed performance depending on the specific subprogramme considered, whereas TEMPORARY WAGE SUBSIDY appears to be a successful programme in terms of increasing the chances on the labour market. With respect to the heterogeneity by subpopulation it appears that participating in programme in the early stages of the unemployment spell is less effective than participating in later stages. We argue that this is due to the fact that participation reduces the number of job offers received compared to nonparticipation. This appears to be particularly damaging for people that would be good matches to these offers. For those with a longer duration of unemployment sorting will have already eliminated the best matches and hence the positive (human capital enhancing) effect of the programme will be more important than the temporary reduction of received job offers.

The plan of the paper is as follows: The next section gives the stylised facts of the Swiss labour market and explains the institutional arrangements of the unemployment insurance system. Furthermore, it gives the details of the active labour market policies under consideration in this study. Section 3 discusses data issues, presents descriptive statistics, and empirically characterises the selection processes into the programmes. In section four we discuss our identification and estimation strategy. Section 5 contains the results and Section 6 concludes. Appendix A contains more information about the data and the sample, as well as the complete results of the estimation of a multinomial probit model used to explain participation in the programmes. Finally, additional results of the evaluation can be found in Appendix B. 


\section{The Swiss labour market}

\subsection{The economic situation}

Switzerland is a small country in Western Europe. It is a federalist state with three major language regions. There is considerable heterogeneity across these regions with respect to economic performance. The German speaking region is by far the largest and economically most prosperous part. The female labour market participation rate is relatively high at about $70 \%$ (with about $55 \%$ of them working part-time). The share of foreigners in the work force is about $20 \%{ }^{3}$

After a long period of economic growth the first seven years of the 1990s proved to be a period of stagnation. This resulted in an output gap which is estimated to be the largest of all OECD countries. The main causes of this long period of stagnation were probably tight monetary conditions, fiscal consolidation, a slow-down in export market growth and restructuring in several sectors of the Swiss economy (in particular a massive downsizing of the construction sector). Only in 1998 the economy started to recover.

Switzerland has a rather unique unemployment experience within Western Europe. Before 1990 unemployment never was a major problem. In the 1970s the unemployment rate never exceeded $1 \%$ and in the 1980 s the highest rate was $1.1 \%$ in 1982 . After 1990 the unemployment rate increased markedly and reached a maximum of $5.2 \%$ in 1997. Since then unemployment has decreased again considerably to $2.8 \%$ in $1999 .{ }^{4}$ The main reason why recessions before 1990 did not translate into a large increase in unemployment as in most other Western European countries seems to be the cyclical responsiveness of the foreign labour force. These foreigners are persons with different categories of work permits: a) seasonal permits (9 months), b) annual permits, c) permanent permits, and d) frontier workers (living abroad, but close to the Swiss boarder). According to OECD (1996) about 75\% of the employment reduction in the 1975/76 recession was absorbed by a reduction in the non-permanent foreign labour force. ${ }^{5}$ The situation was considerably different in the 1990s with more than $60 \%$ of the foreign labour force having a permanent work permit, implying a much reduced responsiveness. In addition female labour supply also became much less elastic with respect to labour demand (OECD, 1996).

\footnotetext{
The source for most of the numbers presented in this section is OECD (1996).

The OECD standardised unemployment rates are somewhat lower then those based on the Swiss official statistics.

5 Non-permanent work permits are only renewed in case of successful employment.
} 
As a result foreigners are overrepresented among the unemployed with a share of roughly $40 \%$. This is also the case for women whose unemployment rate is about one percentage point higher than the overall unemployment rate. Youth unemployment, although showing a larger rate than overall unemployment (7\% vs. $4.7 \%$ in 1994), is not a major problem, as opposed to many other OECD countries. Switzerland has a dual vocational training system comparable to the German system. However, there is a remarkable disparity in youth unemployment rates between the German speaking cantons and the non-German speaking cantons. The youth unemployment rate in 1994 was $3.5 \%$ in the former cantons and $12.5 \%$ in the latter cantons (OECD, 1996). This disparity is also evident in the overall unemployment rates which are about twice as large in the nonGerman speaking cantons (7.1\% vs. $3.4 \%$ in 1995$)$.

Switzerland had no compulsory unemployment insurance until the late 1970s. The national unemployment insurance law (AVIG) was enacted only as late as 1984. It set the maximum entitlement to unemployment benefits to 50 weeks provided the unemployed had contributed to the insurance for at least 6 months within the 12 months prior to the unemployment spell. The unemployment benefit is paid by the federal unemployment insurance. When the entitlement period has expired the unemployed has to rely on social assistance provided by the community he is living in. Active labour market policies were provided for in the AVIG but due they were never of any importance before 1996.

As a reaction to rising unemployment in the early 1990s the entitlement period for unemployment benefits was increased in several steps to 80 weeks. The entitlement condition was relaxed to having contributed for at least six months within the previous 24 months. However, this policy of making the insurance more generous got under political pressure. This eventually lead to a revision of the unemployment insurance law which was enacted in 1996.

\subsection{The 1996 revision of the unemployment insurance law and the active labour market policy}

The main feature of the revision of the unemployment insurance law is a change from so-called passive unemployment benefits towards an active system in which benefit payments are conditional on participation in labour market programmes. ${ }^{6}$ Benefit entitlement was prolonged to two years. The entitlement period is separated into two parts: the first 30 weeks are unconditional on 
programme participation whereas the remaining entitlement is conditional on some participation. However, in practice these rules have not been strictly enforced. On the one side, it is not unusual to participate in programmes in the first 30 weeks of the unemployment spell. In this case the unconditional benefit payments can be received at a later stage. On the other side, and much more important in terms of occurrences, if no suitable programme has been offered to the unemployed after the unconditional period has been exhausted, the unemployed continues to receive the same benefits as before without any participation in ALMP.

Entitlement is conditional on having contributed to the unemployment insurance for at least 6 months in the past 24 months. After the entitlement period has expired, getting a new two entitlement period is conditional on being employed for at least 12 months within three years after the previous unemployment spell. The replacement ratio is in general $80 \%$ of the insured earnings. ${ }^{7}$ The maximum of the monthly benefit is limited to about CHF 7000.

The revised law also requires the creation of regional placement offices. The purpose of these offices is to provide services to both the unemployed and the employers. This should be achieved by establishing a close contact to both groups which ought to help to reintegrate the unemployed. The consultants in the placement offices should be assigned between 75 and 150 unemployed which they should meet on a monthly basis for a in-depth interview. This is a rather unique set-up for a Western country (OECD 1996).

The cantons are obliged by the law to supply a minimum of places in labour market programmes per year. Until January 2000 this minimum was $25^{\circ} 000$ places for the entire country and distributed across cantons according to their unemployment rates. This minimum was exceeded in 1998 by roughly 6000 programme places. By comparison, the average stock of job-seekers was roughly 190’000 in 1997 and 140’000 in 1998.

The active labour market programmes (ALMP) can be grouped into 3 broad categories: a) training courses, b) employment programmes, and c) temporary employment with wage subsidy (TEMPORARY WAGE SUBSIDY, which is officially called "intermittent pay"). The former two groups are fairly standard but they encompass a very heterogeneous variety of programmes (see below). The last type of programme is rather unique, however. The difference between $b$ ) and c)

\footnotetext{
The amount of benefits is the same for the active as well as passive ones.

7 A reduced replacement ratio of $70 \%$ applies to able bodied persons with parental obligations with previous monthly earnings above about CHF 3500.
} 
is that employment programmes take place outside the "regular" labour market. ${ }^{8}$ By contrast TEMPORARY WAGE SUBSIDY must be a regular job.

Training programmes consist of a wide variety of courses, ranging from basic courses to specific work-related training. The decision to participate in a training course is made by the placement officer according to his impressions obtained mainly from the monthly interviews. The unemployed can also apply for training courses. The law requires that courses must be necessary and adequate with the goal to improve individual employment chances. Criteria for the decision include age and motivation of the unemployed, and the duration of the course and its relevance for the occupation. Occupational retraining is specifically not considered to be a task of the ALMP. This implies that courses for further vocational training are within the occupation of the unemployed. The duration of training courses varies generally between one day and several months.

Employment programmes usually last for six months. They should be as similar as possible to a regular employment, but they should be extraordinary, i.e. employment programmes should not be in competition with other firms. Employment programmes are offered by both public and private institutions. During an employment programme the unemployed has to continue his job search and must accept any suitable job offer. While in an employment programme an unemployed receives a wage which can be larger than the unemployment benefit. However, in practice this appears to be an exception.

Participation in both training courses and employment programmes does not extend the benefit entitlement period. ${ }^{9}$ By contrast TEMPORARY WAGE SUBSIDY can extend the entitlement period if its cumulated duration exceeds 12 months.

The objective of TEMPORARY WAGE SUBSIDY is to encourage job seekers to accept job offers that pay less than their unemployment benefit by compensating the difference with additional payments. The income generated by this scheme is larger than the unemployment benefit in case of not accepting the temporary job. ${ }^{10}$ Thus this measure is financially attractive for both the unemployed and the placement office. Note that TEMPORARY WAGE SUBSIDY does not belong to the ALMP officially but there is compelling evidence that the placement offices intentionally use

8 According to the law jobs in employment programmes should not compete with regular jobs.

In fact before 1997 participation in employment programmes did lead to an extension of the entitlement period.

10 The compensation payment is the replacement ratio applied to the difference between the earnings in the temporary job and the previous earnings which will always be larger than the difference between the unemployment benefit and the earnings in the temporary job. At the same time the unemployment insurance system 'saves money' by always paying less than the regular unemployment benefit. 
them as an active labour market policy instrument. This is documented in a specific evaluation of the intermittent pay employment (Bauer, Baumann, and Künzi, 1999) and in interviews we conducted at selected placement offices. Not surprisingly it is the largest programme of the ALMP. In 1998 roughly 20\% of the unemployed were at some point in TEMPORARY WAGE SUBSIDY. For this reason we treat them as part of the ALMP. Bauer, Baumann, and Künzi, (1999) report that only about $20 \%$ of the jobs in TEMPORARY WAGE SUBSIDY are arranged by the placement office. The OECD (1996) states that TEMPORARY WAGE SUBSIDY can be a very powerful instrument to bring unemployed back to employment. However, there is concern that it can become a serious distortion in the labour market if it is not tightly monitored. For example, workers might be laid-off and recalled in the TEMPORARY WAGE SUBSIDY scheme. Furthermore, firms might use TEMPORARY WAGE SUBSIDY to avoid the dismissal protection rules in order to have a more flexible work force, or TEMPORARY WAGE SUBSIDY might be used to avoid the wage levels set out in collective wage bargaining agreements. However, at the moment there appears to be no evidence that TEMPORARY WAGE SUBSIDY has these negative effects in practice.

Switzerland is a highly federalist country. This implies that the cantons and even the placement offices within a canton are relatively free regarding their policy of allocating unemployed to programmes. They just have to conform to the rather vague guidelines set out in the federal law. This introduces a rather strong regional heterogeneity into the allocation process that is evident from both the interviews we conducted and the estimation results of the factors explaining the selection process presented below.

Informative data are most important in evaluation studies, because they allow to disentangle differences between participants and nonparticipants due to selective participation from differences caused by the specific programme. Since we use data from the administrative unemployment register in principle we know as much about the unemployed as the placement officer knows. We also need to know everything about the type, timing and duration of the programmes. In addition we must be able to measure the success of the programmes, e.g. by information on successful employment. Again, by using the administrative data we have exactly this information. In addition there is striking evidence in the literature (see the survey by Heckman, LaLonde, and Smith, 1999) that it is extremely important to control for individual labour market histories in order to capture individual heterogeneity. We are able to do this because it was possible to merge data from the social security records with the unemployment registrar data. By this we have retro- 
spective data on labour market status and earnings covering at most ten years prior to the current unemployment spell. Overall we believe that we have very good data at hand to perform a comprehensive evaluation of the Swiss ALMP. The data will be described in more detail in section 3. We now discuss the programmes in more detail. There is a wide variety of 16 different training courses that we aggregate in five relatively homogenous groups: a) basic courses (aiming at improving the effectiveness of job search and self-esteem), b) language courses, c) computer courses, d) further vocational training, and e) other courses (including specific courses for specific occupations). ${ }^{11}$ The employment programmes are differentiated according to whether they are offered by public or private institutions. TEMPORARY WAGE SUBSIDY is a programme of its own, and the final group consists of those who never participated in any programme. Thus in total we have nine groups of ALMP participation status to which we allocate the individuals in our data.

With respect to programme heterogeneity, there is a fundamental problem we have to address: how do we deal with multiple programme participation of the same unemployed? In principle, it is possible to observe individuals with programme "careers" where participation in a later programme is of course not independent of prior participation. This creates an endogeneity problem, because more successful programmes will increase the likelihood of employment for their participants, while less successful programmes may just lead to yet another programme participation. For this reason we evaluate only the first major programme. This approach implies that further programme participation is an indicator of failure of the first programme because it does not bring the unemployed back into employment. In practice this approach is less restrictive than it appears. Only about $30 \%$ of all participants enter a second programme, and the majority of these successive programs are of the same type as the first programme.

Another problem concerns the group of nonparticipants. For this group important time varying variables like 'unemployment duration prior to the programme' are not defined. To make meaningful comparisons to those unemployed entering a programme, we use an approach suggested in Lechner (2000b) in which we draw for each nonparticipant a hypothetical programme starting date from the sample distribution of starting dates. Persons with simulated starting date later than their actual exit date from unemployment are excluded from the data set.

\footnotetext{
11 See Table A.1 in Appendix A.1 for details on the aggregation of the groups.
} 
To summarize we evaluate the first major programme starting after January 1, 1998. A major programme is defined as having a duration of at least two weeks. The reason not to consider programmes starting before 1998 is that the data does not contain sufficient information on the type and the duration of programmes prior to $1998 .^{12}$

Table 1: Number of observations and selected characteristics of different groups

\begin{tabular}{|c|c|c|c|c|c|c|c|c|}
\hline \multirow[t]{2}{*}{ Group } & & \multirow{2}{*}{$\begin{array}{c}\text { obs. } \\
\text { (persons) }\end{array}$} & \multirow{2}{*}{$\begin{array}{c}\text { duration of } \\
\text { programme } \\
\text { (mean } \\
\text { days) }\end{array}$} & \multicolumn{2}{|c|}{$\begin{array}{l}\text { unemployment } \\
\text { before... }\end{array}$} & \multirow{2}{*}{$\begin{array}{l}\begin{array}{l}\text { qualifi- } \\
\text { cation }\end{array} \\
\text { (mean) }\end{array}$} & \multirow{2}{*}{$\begin{array}{l}\text { foreign } \\
\text { (share } \\
\text { in } \%)\end{array}$} & \multirow{2}{*}{$\begin{array}{l}\text { employ- } \\
\text { ed March } \\
1999 \\
\text { (share } \\
\text { in \%) }\end{array}$} \\
\hline & & & & $\begin{array}{l}\text { (mean } \\
\text { days) }\end{array}$ & $\begin{array}{l}\text { (share of } \\
\text { duration < } \\
150 \text { days) }\end{array}$ & & & \\
\hline NONPARTICIPATION & (NONP) & 6918 & 0 & 240 & & 1.8 & 47 & 39 \\
\hline BASIC COURSES & (BAC) & 1491 & 46 & 236 & 36 & 1.8 & 45 & 32 \\
\hline LANGUAGE COURSES & (LAC) & 1719 & 71 & 225 & 36 & 2.2 & 72 & 29 \\
\hline COMPUTER COURSES & (COC) & 1394 & 36 & 214 & 40 & 1.3 & 22 & 44 \\
\hline FURTHER VOCATIONAL TRAINING & (FVT) & 424 & 74 & 231 & 35 & 1.6 & 38 & 42 \\
\hline OTHER TRAINING COURSES & (OTC) & 497 & 94 & 263 & 23 & 1.8 & 43 & 42 \\
\hline EMPLOYMENT PROGRAMMES (PUBLIC) & (EP-PU) & 1124 & 153 & 302 & 18 & 1.7 & 41 & 28 \\
\hline EMPLOYMENT PROGRAMMES (PRIVAT) & (EP-PR) & 1349 & 142 & 299 & 18 & 2.0 & 51 & 25 \\
\hline TEMPORARY WAGE SUBSIDY & (TEMP) & 4390 & 114 & 228 & 35 & 1.7 & 46 & 48 \\
\hline
\end{tabular}

Note: Qualification is measured as skilled (1), semiskilled (2), and unskilled (3).

Table 1 shows the descriptive statistics of several important variables across the different groups. The largest group is NONPARTICIPATION (about one third) which is interesting given that programme participation is in principle compulsory after 150 days. The largest programme group is TEMPORARY WAGE SUBSIDY. All other programmes are of similar size except FURTHER VOCATIONAL TRAINING and OTHER COURSES. The final column shows that the employment rate at the final day in our data varies considerably between $48 \%$ and $25 \%$. Of course, this is not indicative for programme success because the composition of different groups of participants do differ substantially with respect to variables influencing future employment, so that we expect differences for these different groups of unemployed even when they would not have participated in any programme. The table shows that important variables like qualification, nationality and duration of unemployment also vary substantially. Further analysis presented in Section 3.2 shows that the differences are even more pronounced. The proportion of those who started the programme in the first 150 days of the unemployment spell (remember that programme participation is in principle compulsory after 150 days) is also interesting, since it is rather low for the employment pro-

${ }^{12}$ Comprehensive coverage of labour market programmes in the official statistics was only introduced in 1998. 
grammes with $18 \%$ and about twice as large for most other programmes (except OTHER TRAINING COURSES). This indicates that especially training courses and TEMPORARY WAGE SUBSIDY often start earlier than required by law.

At the moment there are no detailed information available on programme costs. Therefore, at this point it is not possible to perform a cost benefit analysis.

\section{Data and empirical analysis of the selection process}

\subsection{Data base}

Our empirical analysis is based on administrative data. We obtained access to the information system for placement and labour market statistics (AVAM) and the unemployment offices payment systems (ASAL). From there we got data from January 1996 to March 1999 for all persons who were registered as unemployed on December 31, 1997 (about 180’000). These data provide very detailed information about the unemployment history, ALMP participation and personal characteristics. In addition we received data from the social security records for the period 19881997 , albeit only for a random subsample of about $25^{\prime} 000$ observations. The merged sample contains information on the individual labour market histories and earnings for at most 10 years prior to the current unemployment spell.

As indicated in the previous section we need very good data for the evaluation. We believe that the data we have at hand are indeed excellent for our purposes. In particular we have the detailed information concerning several aspects: sociodemographics (age, gender, marital status, native language, nationality, type of work permit, language skills); local region (town/village and labour office in charge); subjective valuations of placement officer (qualifications, chances to find job), sanctions imposed by the placement office; previous job and desired job (occupation, sector, position, earnings, full- / part-time); a short history of labour market status on a daily basis, and the employment status and earnings on a monthly basis for the last ten years.

Particularly the subjective valuations of the placement officers and the benefit sanctions can be very informative since they will capture characteristics like motivation and personal appearance that are usually unobservable. We are confident that after controlling for this wealth of informa- 
tion there is little unobserved heterogeneity left that is systematically correlated with labour market outcomes and programme participation.

We applied a series of sample selection rules to the data. Full details are given in Appendix A1. The most important selection criteria are that we consider only individuals unemployed on Dec 31,1997 , for no more than twelve months who have not participated in any major programme in 1997 and who are between 25 and 55 years old.

The reasons for these selection criteria are that given the two-year entitlement period we want to make sure that there is sufficient time left to participate in a programme after December 31, 1997. Furthermore, given our concentration on the first major programme we need to exclude those who participated in a major programme before. In addition given the variety of options for young (schooling) and older unemployed (early retirement) we decided to exclude these from our analysis.

The final data set has 19307 observations. Table A.2 in Appendix A.2 shows the complete descriptive statistics of the data set used.

\subsection{Empirical analysis of participation process into the programmes}

This section describes the results of estimating a multinomial probit model for the selection of the individuals into the several programme categories. ${ }^{13}$ The full results are presented in Table A.4 and A.5 in Appendix A.3.

The results indicate that the main determinants of the selection process into the programmes are gender, region of residence, unemployment and programme participation history, qualification, knowledge of language, and previous occupation.

The results of the estimation of the determinants of the programme selection process correspond to what we would expect from the legal requirements and our interviews at selected placement offices. It seems that the unemployed are sent into programmes that are adequate with respect to their skill levels and requirements for improving their employment chances. This is especially the case for foreigners whose mother tongue is not the language spoken in the canton they live in.

\footnotetext{
13 The multinomial probit has been estimated by maximum simulated likelihood using the GHK simulator (100 replications for each individual observation in each equation). NONPARTICIPATION is chosen as the reference group. We chose the multinomial probit as opposed to the multinomial logit because it does not impose the restrictive independence of irrelevant alternatives assumption.
} 
These individuals usually enter LANGUAGE COURSES and are much less likely to go to COMPUTER COURSES, FURTHER VOCATIONAL TRAINING and TEMPORARY WAGE SUBSIDY.

Low-skilled unemployed are likely to be selected into LANGUAGE COURSES and both types of EMPLOYMENT PROGRAMMES. On the other hand, unemployed with a higher skill level tend to go to COMPUTER COURSES, FURTHER VOCATIONAL TRAINING, and TEMPORARY WAGE SUBSIDY. Women are more likely to enter BASIC COURSES, LANGUAGE COURSES, and TEMPORARY WAGE SUBSIDY. The probability for entering EMPLOYMENT PROGRAMMES increases with age.

A main determinant of BASIC TRAINING is residential location. This is a result of the federalist system allowing placement offices some discretion with respect to the classification of actual programmes in the official groups (here mainly between BASIC and LANGUAGE COURSES).

Considering the employment history coded from the social security records we find that the proportion of time unemployed in the previous ten years has a positive effect on the probability to enter an EMPLOYMENT PROGRAMME. For all other programmes this coefficient is negative. On the other hand the proportion of time being employed in the last ten years has only a positive impact on the probability of entering TEMPORARY WAGE SUBSIDY. Overall this finding suggests that the unemployed in TEMPORARY WAGE SUBSIDY seem to have a stronger attachment to the labour market in terms of successful employment.

Finally, we find large positive correlations between the unobserved components relating to the two employment programmes, whereas the corresponding correlations between training programmes are mainly negative. Not surprisingly, the negative correlation between LANGUAGE COURSES and COMPUTER COURSES is the largest one. However, the estimation of these correlations appears to be rather imprecise.

Table 2 displays the correlation matrix of the predicted probabilities of entering the programmes. In general we find negative correlations with two exceptions: the correlations between the probabilities of COMPUTER COURSES and FURTHER VOCATIONAL TRAINING and between the two types of EMPLOYMENT PROGRAMMES implying that participants in these two pairs of programmes are fairly similar. 
Table 2: Correlations of predicted probabilities

\begin{tabular}{|c|c|c|c|c|c|c|c|c|c|}
\hline & \multirow[t]{2}{*}{ Nonpart. } & \multirow[t]{2}{*}{$\begin{array}{c}\text { basic } \\
\text { courses }\end{array}$} & \multirow[t]{2}{*}{$\begin{array}{c}\text { language } \\
\text { course }\end{array}$} & \multirow[t]{2}{*}{$\begin{array}{c}\text { computer } \\
\text { course }\end{array}$} & \multirow[t]{2}{*}{$\begin{array}{l}\text { vocat. } \\
\text { training }\end{array}$} & \multirow[t]{2}{*}{$\begin{array}{l}\text { other } \\
\text { training }\end{array}$} & \multicolumn{2}{|c|}{$\begin{array}{l}\text { employment } \\
\text { programme }\end{array}$} & \multirow{2}{*}{$\begin{array}{c}\text { temporary } \\
\text { wage } \\
\text { subsidy }\end{array}$} \\
\hline & & & & & & & public & private & \\
\hline NONP & 1 & -0.33 & -0.21 & -0.10 & -0.09 & -0.05 & -0.28 & -0.31 & -0.32 \\
\hline$B A C$ & & 1 & 0.03 & 0.07 & 0.03 & -0.03 & 0.02 & 0.00 & -0.15 \\
\hline LAC & & & 1 & -0.26 & -0.17 & -0.02 & -0.23 & -0.16 & -0.31 \\
\hline $\mathrm{COC}$ & & & & 1 & 0.39 & -0.07 & -0.13 & -0.29 & -0.13 \\
\hline FVT & & & & & 1 & -0.09 & -0.03 & -0.13 & -0.12 \\
\hline OTC & & & & & & 1 & -0.03 & 0.02 & -0.19 \\
\hline TE-PU & & & & & & & 1 & 0.20 & -0.04 \\
\hline TE-PR & & & & & & & & 1 & -0.05 \\
\hline TEMP & & & & & & & & & 1 \\
\hline
\end{tabular}

\section{Econometric estimation of the effects of ALMP}

\subsection{Notation and definition of causal effects}

\subsubsection{Notation}

The prototypical model of the microeconometric evaluation literature is the following: An individual can choose between two states (causes), like participation in a training programme or nonparticipation in such a programme. The potential participant in a programme will get an hypothetical outcome (e.g. earnings) in both states. This model is known as the Roy (1951) - Rubin (1974) model of potential outcomes and causal effects. ${ }^{14}$

Consider the outcomes of $(M+1)$ different mutually exclusive states denoted by $\left\{Y^{0}, Y^{1}, \ldots, Y^{M}\right\}$. The different states will to be called treatments in the following to stick to the terminology of that literature. It is assumed that each individual receives exactly one of the treatments (typically, category '0' denotes treatment type no treatment). Therefore, for any individual, only one component of $\left\{Y^{0}, Y^{1}, \ldots, Y^{M}\right\}$ can be observed in the data. The remaining $M$ outcomes are counterfactuals. Participation in a particular treatment $m$ is indicated by the variable $S \in\{0,1, \ldots M\}$.

\footnotetext{
${ }^{14}$ See for example Holland (1986) for an extensive discussion of concepts of causality in statistics, econometrics, and other fields.
} 


\subsubsection{Pair-wise effects}

The definitions of average treatment effects used for the case of just two treatments need to be extended. ${ }^{15}$ In the following equations, the focus is on a pair-wise comparison of the effects of treatments $m$ and $l$ :

$\gamma_{0}^{m, l}=E\left(Y^{m}-Y^{l}\right)=E Y^{m}-E Y^{l}$

$\theta_{0}^{m, l}=E\left(Y^{m}-Y^{l} \mid S=m\right)=E\left(Y^{m} \mid S=m\right)-E\left(Y^{l} \mid S=m\right)$.

$\gamma_{0}^{m, l}$ denotes the expected (average) effect of treatment $m$ relative to treatment $l$ for a participant drawn randomly from the population. ${ }^{16}$ Note that both average treatment effects are symmetric in the sense that $\gamma_{0}^{m, l}=-\gamma_{0}^{l, m} . \theta_{0}^{m, l}$ is the expected effect for an individual randomly drawn from the population of participants in treatment $m$ only. Note that if the participants in treatments $m$ and $l$ differ in a way that is related to the distribution of $X$, and if the treatment effects vary with $X$, then $\theta_{0}^{m, l} \neq-\theta_{0}^{l, m}$, i.e. the treatment effects on the treated are not symmetric.

\subsubsection{Composite effects}

In our case the $72(9 * 8)$ pair-wise comparisons may not be considered a sufficiently dense summary of the causal effects, the following modifications can be used to define a composite effect by using appropriate weight functions to aggregate the treatments other than $m$ :

$$
\begin{array}{ll}
\gamma_{0}^{m}\left(v^{m}\right)=\sum_{l=0}^{M} v^{m, l} \gamma_{0}^{m, l}, & v^{m}=\left(v^{m, 0}, \ldots, v^{m, M}\right) \\
\theta_{0}^{m}\left(v^{m}\right)=\sum_{l=0}^{M} v^{m, l} \theta_{0}^{m, l} .
\end{array}
$$

\footnotetext{
15 Assume for the rest of the paper that the typical assumptions of the Rubin model are fulfilled (see Holland, 1986, or Rubin, 1974, for example).

16 If a variable $Z$ cannot be changed by the effect of the treatment then all what follows is also valid in strata of the data defined by different values of $Z$.
} 
The particular weights used in the empirical part are the relative participation frequencies $\left[P(S=l \mid S \neq m)=\frac{P(S=l)}{1-P(S=m)}, m \neq l\right]$. It is shown elsewhere (Lechner, 2000b) that these composite effects have a causal interpretation: they correspond to the effects of treatment $m$ compared to a state were the treated would be randomly assigned to one of the other treatments with probabilities given by the weights.

\subsection{Identification}

\subsubsection{The conditional independence assumption}

The causal model clarifies that the average causal treatment effect is generally not identified. Therefore, the lack of identification has to be overcome by plausible, untestable assumptions. Their plausibility depends on the problem analyzed and the data available. The papers by Angrist and Krueger (1999), Heckman and Robb (1986), and Heckman, LaLonde, and Smith (1999) provide an excellent overview about available identification strategies. Here, we already made clear in the previous section that the data is so rich, that it seems plausible that we can observe all important factors that jointly influence labour market outcomes and the process selecting people into the nine states. Therefore, we assume that treatment participation and treatment outcome is independent conditional on a set of (observable) attributes (conditional independence assumption, CIA, Rubin, 1977). Rosenbaum and Rubin (1983) show how this assumption could effectively be used for semi- / nonparametric treatment evaluation, since it is not necessary to condition on a potentially high number of attributes, but only on the participation probability conditional on the attributes. $^{17}$

Imbens (1999) and Lechner (1999a) consider identification under the conditional independence assumption (CIA) in the model with multiple treatments. CIA defined to be valid in a subspace of the attribute space is formalised in expression (5):

$Y^{0}, Y^{1}, \ldots, Y^{M} \amalg S \mid X=x, \forall x \in \chi$.

\footnotetext{
${ }^{17}$ See for example Section X in the paper by Heckman and Robb (1986) for the link between matching on the propensity score and classical selection models.
} 
This assumption requires the researcher to observe all characteristics that jointly influence the outcomes as well as the selection into the treatments. In that sense, CIA may be called a 'data hungry' identification strategy. ${ }^{18}$ In addition it is required that all individuals in that subspace actually have the possibility to participate in all states (i.e. $0<P(S=m \mid X=x), \forall m=0, \ldots, M$, $\forall x \in \chi$ ). Lechner (1999a) shows that CIA identifies all effects defined in this section.

We already argued in section 3 that our database is exceptionally good, so that we are very confident that all factors that remain unobserved do not systematically influence the participation process in the programmes as well as the labour market outcomes.

\subsubsection{Reducing the dimension using balancing scores}

The basic ingredients of the final estimate are estimates of $E\left(Y^{m} \mid X, S=m\right)$, since CIA implies that $E\left(Y^{m} \mid S=l\right)=E_{X}\left[E\left(Y^{m} \mid X, S=m\right) \mid S=l\right]$. However, nonparametric estimates cannot easily be obtained, because of the high dimension of $X$ and the resulting curse of dimensionality in any nonparametric estimator. ${ }^{19}$ In that respect, Lechner (1999a) shows also that some modified versions of the balancing score properties known from the binary treatment model (Rosenbaum and Rubin, 1983) hold in this more general setting as well. In the following the basic results of Lechner (1999a) are repeated.

Denote the choice probability of alternative $j$ conditional on $X$ as $P(S=j \mid X=x)=P^{j}(x)$, we get the following result for the effect of treatment $m$ compared to treatment $l$ on the participants in treatment $m$ :

$\theta_{0}^{m, l}=E\left(Y^{m} \mid S=m\right)+\underset{P^{l \mid m l}(X)}{E}\left[E\left(Y^{l} \mid P^{l \mid m l}(X), S=l\right) \mid S=m\right]$

$$
P^{l \mid m l}(x)=P^{l \mid m l}(S=l \mid S=l \text { or } S=m, X=x)=\frac{P^{l}(x)}{P^{l}(x)+P^{m}(x)} .
$$

\footnotetext{
${ }^{18}$ Note that CIA is not the minimal identifying assumption, because all what is needed to identify mean effects is conditional mean independence. However, CIA has the virtue of making the latter valid for all transformations of the outcome variables. Furthermore, in this study it would be difficult to argue why conditional mean independence should hold and CIA might nevertheless be violated.

19 Since identification is obtained nonparametrically, it appears natural to avoid imposing a functional form on $E\left(Y^{m} \mid X, S=m\right)$ for the purpose of ease of estimation (thus avoiding the danger of inconsistent estimates due to incorrect imposition of functional forms, that have carefully be avoided beforehand).
} 
If the respective probabilities $P^{l \mid m l}(x)$ are known or if a good estimator is available, i.e. a consistent estimator that converges at the parametric rate, the dimension of the (nonparametric) estimation problem is reduced to one. If $P^{l \mid m l}(x)$ is modelled directly, no information from subsamples other than the ones containing participants in $m$ and $l$ is needed for identification and estimation of $\theta_{0}^{m, l}$ and $\theta_{0}^{l, m}$.

The equality $E\left(Y^{l} \mid S=m\right)=E_{X}\left[E\left(Y^{l} \mid P^{l \mid m l}(X), S=l\right) \mid S=m\right]$ suggests a similar strategy of identifying (and estimating) the population effect $\gamma_{0}^{m, l}$ :

$$
\begin{aligned}
\gamma_{0}^{m, l} & =E Y^{m}-E Y^{l}=\sum_{j=0}^{M}\left[E\left(Y^{m} \mid S=j\right)-E\left(Y^{l} \mid S=j\right)\right] P(S=j) \\
& =\sum_{j=0}^{M}\left\{E_{X}\left[E\left(Y^{m} \mid P^{m \mid m j}(X), S=m\right) \mid S=j\right]-E_{X}\left[E\left(Y^{l} \mid P^{l l \mid j}(X), S=l\right) \mid S=j\right]\right\} P(S=j)
\end{aligned}
$$

In this evaluation it will be more straightforward from a modelling point of view to specify the complete discrete choice problem of choosing a particular treatment out of the complete list of treatments simultaneously (see section 3 ). $P^{l \mid m l}(x)$ could then be computed from that model. In this case, we have consistent estimates of all marginal choice probabilities $\left[P^{0}(X), \ldots, P^{M}(X)\right]$. Hence, it may be attractive to condition jointly on $P^{l}(X)$ and $P^{m}(X)$ instead of $P^{l \mid m l}(X)$. This also identifies $\theta_{0}^{m, l}$, because $P^{l}(X)$ together with $P^{m}(X)$ is 'finer' than $P^{l \mid m l}(X)$, since $E\left[P^{l \mid m l}(X) \mid P^{l}(X), P^{m}(X)\right]=E\left[\frac{P^{l}(X)}{P^{l}(X)+P^{m}(X)} \mid P^{l}(X), P^{m}(X)\right]=P^{l \mid m l}(X)$.

Making use of equations (6) and (7) allows the strategy to estimate $E\left(Y^{l} \mid S=m\right)$ for all combinations of $m$ and $l$, and then to use these estimates to compute the different treatment effects $\gamma_{0}^{m l}$ and $\theta_{0}^{m l}$. Such an estimator is proposed next. ${ }^{20}$

\footnotetext{
${ }^{20}$ The composite effects are obtained by appropriate aggregation of the pair-wise effects (see equations (3) and (4)).
} 


\subsection{A matching estimator}

Given the choice probabilities, or a consistent estimate of them, the terms appearing in equations (6) and (7) can be estimated by any parametric, semiparametric, or nonparametric regression method that can handle one or two-dimensional explanatory variables. One of the popular choices of estimators in a binary framework is matching (for recent examples see Angrist, 1998, Dehejia and Wahba, 1999, Heckman, Ichimura, and Todd, 1998, Heckman, Ichimura, Smith, and Todd, 1998, and Lechner, 1999b, 2000a). The idea of matching on balancing scores is to estimate $E\left(Y^{m} \mid S=l\right)$ by forming a comparison group of selected participants in $m$, that have the same distribution of the balancing score (here $P^{l \mid m l}(X)$ or $\left.\left[P^{l}(X), P^{m}(X)\right]\right)$ than the group of participants in $l$. By virtue of the property of being a balancing score, the distribution of $X$ will also be balanced in the two samples. The estimator of $E\left(Y^{m} \mid S=l\right)$ is then simply the mean in that selected comparison group. Compared to kernel estimates, a major advantage of matching is clearly its simplicity and its intuitive appeal. ${ }^{21}$ Advantages compared to parametric approaches are its robustness to the functional form of the conditional expectations (w.r.t. $E\left(Y^{m} \mid X, S=m\right)$ ) and that it leaves the individual causal effect completely unrestricted and hence allows arbitrary heterogeneity of the effect in the population.

Lechner (1999a, b) proposes and compares different matching estimators that are analogous to the rather simple matching algorithms used in the literature on binary treatments. Since the estimators based on $\left[P^{l}(X), P^{m}(X)\right]$ appear to be superior to the ones based on $P^{l \mid m l}(X)$, the former are used to estimate the effects of the ALMP in this paper (see Table 3).

\footnotetext{
${ }^{21}$ One might conjecture that matching will be superior in small samples, but as of now, the evidence is very limited.
} 
Table 3: A matching protocol for the estimation of $\gamma_{0}^{m, l}$ and $\theta_{0}^{m, l}$

\begin{tabular}{|c|c|}
\hline Step 1 & Specify and estimate a multinomial probit model to obtain $\left[\hat{P}_{N}^{0}(x), \hat{P}_{N}^{1}(x), \ldots, \hat{P}_{N}^{M}(x)\right]$. \\
\hline Step 2 & $\begin{array}{l}\text { Restrict sample to common support: Delete all observations with probabilities larger than the smallest } \\
\text { maximum and smaller than the largest minimum of all subsamples defined by } S \text {. }\end{array}$ \\
\hline Step 3 & $\begin{array}{l}\text { Estimate the respective (counterfactual) expectations of the outcome variables. } \\
\text { For a given value of } m \text { and } / \text { the following steps are performed: } \\
\text { a) Choose one observation in the subsample defined by participation in } m \text { and delete it from that } \\
\text { pool. } \\
\text { b) Find an observation in the subsample of participants in / that is as close as possible to the one } \\
\text { chosen in step a) in terms of }\left[\hat{P}_{N}^{m}(x), \hat{P}_{N}^{l}(x)\right] \text {. 'Closeness' is based on the Mahalanobis distance. } \\
\text { Do not remove that observation, so that it can be used again. } \\
\text { c) Repeat a) and b) until no participant in } m \text { is left. } \\
\text { d) Using the matched comparison group formed in c), compute the respective conditional expectation } \\
\text { by the sample mean. Note that the same observations may appear more than once in that group. }\end{array}$ \\
\hline Step 4 & Repeat Step 3 for all combinations of $m$ and $l$. \\
\hline Step 5 & Compute the estimate of the treatment effects using the results of Step 4. \\
\hline
\end{tabular}

Several comments are in order. Step 2 ensures that we estimate only effects in regions of the attribute space where two observations from two treatments could be observed having a similar participation probability. ${ }^{22}$ Otherwise the estimator will give biased results (see Heckman, Ichimura, Smith, Todd, 1998). Table 4 gives the values of the estimated probabilities used to ensure common support.

${ }^{22}$ This condition is also called the 'common-support requirement'. Note that if we would only be interested in pairwise effects the current implementation would be unnecessarily strict, since making sure that there is an overlap for each pair would be sufficient. However, for our purposes of getting the overall picture of the effectiveness of the major programmes of the active labour market policy, it is necessary to evaluate all programmes on the same support. 
Table 4: Minima and maxima of $\left[\hat{P}_{N}^{0}(x), \hat{P}_{N}^{1}(x), \ldots, \hat{P}_{N}^{M}(x)\right]$ in subsamples

\begin{tabular}{|c|c|c|c|c|c|c|c|c|c|}
\hline Subsamples & $\bar{P}^{1}(X)$ & 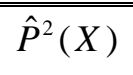 & 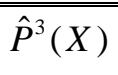 & $\hat{P}^{4}(X)$ & $\bar{P}^{5}(X)$ & 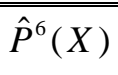 & 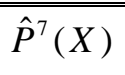 & $\bar{P}^{8}(X)$ & $\bar{c}^{9}(X)$ \\
\hline & \multicolumn{9}{|c|}{ maximum in subsample } \\
\hline NONP & 87 & 35 & 65 & 43 & 38 & 39 & 38 & 52 & 72 \\
\hline BAC & 72 & 34 & 55 & 38 & 39 & 44 & 43 & 54 & 62 \\
\hline LAC & 77 & 29 & 69 & 41 & 32 & 38 & 33 & 51 & 74 \\
\hline $\mathrm{COC}$ & 72 & 38 & 57 & 40 & 28 & 34 & 38 & 42 & 67 \\
\hline FVT & 69 & 32 & 44 & 36 & 32 & 23 & 36 & 42 & 56 \\
\hline OTC & 75 & 27 & 56 & 31 & 21 & 45 & 26 & 39 & 51 \\
\hline TE-PU & 67 & 31 & 68 & 31 & 29 & 54 & 36 & 42 & 67 \\
\hline TE-PR & 75 & 31 & 64 & 40 & 22 & 33 & 49 & 51 & 75 \\
\hline TEMP & 81 & 34 & 63 & 41 & 30 & 48 & 44 & 56 & 80 \\
\hline \multirow[t]{2}{*}{ Minimum of maxima } & 67 & 27 & 44 & 31 & 21 & 23 & 26 & 39 & 51 \\
\hline & \multicolumn{9}{|c|}{ minimum in subsample } \\
\hline NONP & 9.5 & 0.3 & 0.00 & 0.08 & 0.02 & 0.04 & 0.00 & 0.06 & 1.9 \\
\hline BAC & 7.0 & 1.0 & 0.02 & 0.08 & 0.02 & 0.07 & 0.00 & 0.06 & 2.6 \\
\hline LAC & 7.0 & 0.4 & 0.14 & 0.07 & 0.03 & 0.08 & 0.00 & 0.06 & 1.7 \\
\hline $\mathrm{COC}$ & 9.0 & 0.4 & 0.01 & 0.25 & 0.07 & 0.05 & 0.00 & 0.09 & 2.8 \\
\hline FVT & 11 & 0.5 & 0.06 & 0.03 & 0.26 & 0.05 & 0.10 & 0.05 & 4.3 \\
\hline OTC & 8.3 & 0.5 & 0.10 & 0.09 & 0.07 & 0.14 & 0.13 & 0.29 & 3.1 \\
\hline TE-PU & 6.2 & 0.6 & 0.03 & 0.02 & 0.02 & 0.07 & 0.07 & 0.19 & 3.9 \\
\hline TE-PR & 5.9 & 0.3 & 0.03 & 0.02 & 0.04 & 0.16 & 0.05 & 0.29 & 3.0 \\
\hline TEMP & 7.9 & 0.3 & 0.01 & 0.05 & 0.03 & 0.05 & 0.01 & 0.04 & 3.3 \\
\hline Maximum of minima & 11.3 & 1.0 & 0.14 & 0.25 & 0.26 & 0.16 & 0.13 & 0.29 & 4.3 \\
\hline
\end{tabular}

Table 5: Loss of observations due to common support requirement

\begin{tabular}{lccccccccc}
\hline \hline & Nonpart. & basic & lang. & comp. & vocat. & other & employment & temp. \\
courses & course & course & training & training & programme & wage \\
public & private & subsidy \\
\hline Observations before & 6918 & 1491 & 1719 & 1394 & 424 & 497 & 1124 & 1349 & 4390 \\
Observations after & 5987 & 1290 & 1380 & 1237 & 395 & 433 & 978 & 1133 & 3700 \\
\hline Percent deleted & 13.5 & 13.5 & 19.7 & 11.3 & 6.8 & 12.9 & 13.0 & 16.0 & 15.7 \\
\hline \multicolumn{1}{c}{ Then }
\end{tabular}

Note: The total number of observations decreases due to the enforcement of the common support requirement from 19306 to $16533(-14.3 \%)$.

Table 5 shows the distribution of the deleted observation across the different subsamples. Overall the loss of observations is about $14 \%$. Table 5 shows that language courses loose about $20 \%$ of their participants, whereas vocational training courses loose only close to $7 \%$. The other groups are close to the mean loss. Given the results for the language courses, it is not surprising that a comparison of the means of the deleted and the remaining samples reveils that in general the share of unskilled people, foreigners, and women is somewhat higher in the deleted sample (see 
Table A.6 in Appendix A.4). The differences appearing in the distribution of sectors and occupations are probably related to those characteristics.

As a second remark with respect to the matching algorithm outlined in Table 3 concerns the fact that the same comparison observation is used repeatedly in forming the comparison group (matching with replacement). This modification of the 'standard' estimator is necessary for the estimator to be applicable at all when the number of participants in treatment $m$ is larger than in the comparison treatment $l$. Since the role of $m$ and $l$ could be reversed in this framework, this will always be the case when the number of participants is not equal in all treatments. This procedure has the potential problem that very few observations may be heavily used although other very similar observations are available. This may result in a substantial and unnecessary inflation of the variance. Therefore, the potential occurrence of this problem should be monitored (see Table 6).

Table 6: Concentration of the weights due to matching with replacement

\begin{tabular}{lccccccccc}
\hline \hline \multicolumn{1}{c}{$l$} & Nonpart. & $\begin{array}{c}\text { basic } \\
\text { courses }\end{array}$ & $\begin{array}{c}\text { language } \\
\text { course }\end{array}$ & $\begin{array}{c}\text { computer } \\
\text { course }\end{array}$ & $\begin{array}{c}\text { vocat. } \\
\text { training }\end{array}$ & $\begin{array}{c}\text { other } \\
\text { training }\end{array}$ & $\begin{array}{c}\text { employment pro- } \\
\text { gramme } \\
\text { public }\end{array}$ & $\begin{array}{c}\text { temporary } \\
\text { private }\end{array}$ & $\begin{array}{c}\text { wage } \\
\text { subsidy }\end{array}$ \\
\hline NONP & & 35 & 39 & 41 & 34 & 34 & 40 & 41 & 27 \\
BAC & 19 & & 34 & 35 & 32 & 33 & 33 & 32 & 22 \\
LAC & 26 & 36 & & 55 & 54 & 47 & 46 & 46 & 31 \\
COC & 21 & 29 & 31 & & 29 & 37 & 38 & 41 & 24 \\
FVT & 17 & 24 & 27 & 21 & & 31 & 28 & 28 & 21 \\
OTC & 18 & 24 & 27 & 29 & 35 & & 27 & 25 & 19 \\
TE-PU & 20 & 29 & 35 & 39 & 40 & 39 & & 29 & 20 \\
TE-PR & 22 & 32 & 35 & 40 & 40 & 43 & 36 & & 24 \\
TEMP & 24 & 34 & 41 & 41 & 36 & 39 & 37 & 37 & \\
\hline Note: & Share of the largest 10\% of the weights of the respective comparison group relative to the total sum of weights in that
\end{tabular}

Comparing the results in Table 6 with the very limited evidence available from other studies (Lechner, 2000b) values between $17 \%$ and $55 \%$ for the share of the largest $10 \%$ of the weights relative to the sum of the weights in the respective comparison group do not appear to be exceptionally large.

Table 7 compares the mean of the probabilities used for matching in the respective matched comparison sample to the mean of the respective sample of participants. To ensure that the match is not only adequate with respect to the balancing score but also with respect to other important 
variables, such variables are also included in the matching. ${ }^{23}$ Again comparing these number to those obtained by Lechner (2000b) it turns out that they are somewhat higher. This is not surprising because in this study, four additional variables are used. Hence, the quality of the match with respect to the probabilities must necessarily deteriorate. Nevertheless, the level of the mean differences in the various groups appear to be rather small.

Table 7: Are the probabilities used for matching balanced? Results for the mean difference and the standardised mean difference

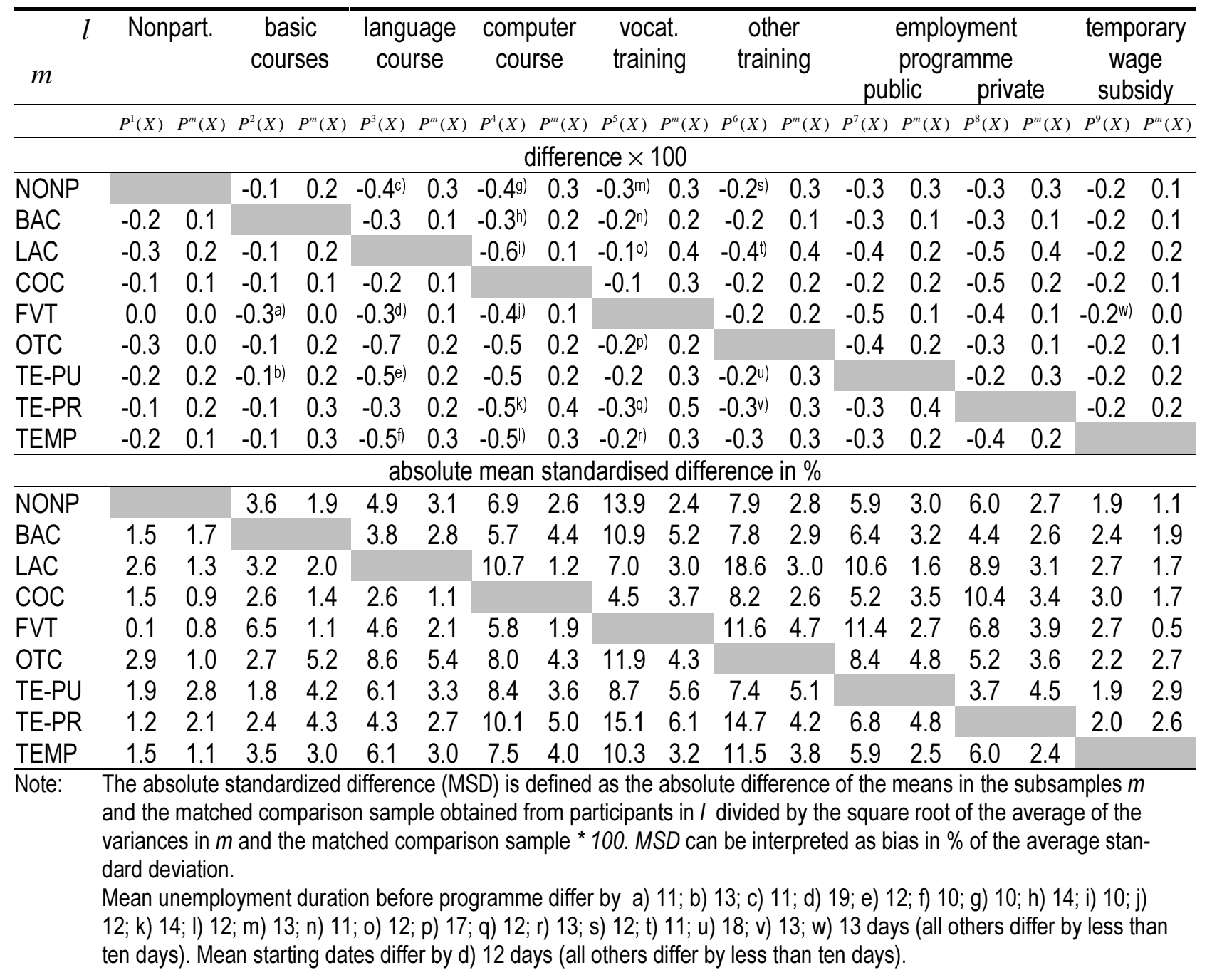

\footnotetext{
${ }^{23}$ Additional variables used for matching: Native language not a Swiss language, gender, begin of programme, and duration of unemployment until begin of programme. The weight in the Mahalanobis distance for the two probabilities is increased by a factor of 5 . For details of this approach see Lechner (1999c).
} 


\section{$5 \quad$ Results}

\subsection{Measures for the effectiveness}

Our goal is to measure the micro effects of participation in the programmes with respect to the outcomes in the labour market. To do so we rely on the data from the unemployment registrars only, because the social security data ends December 1997, just before the programmes start. ${ }^{24}$ This has the direct implication that we can only observe individuals as long as they are registered as unemployed. When they leave the unemployment registrar we observe the destination state of the initial transition out of unemployment (employment, out-of-labour-force). The following transition is however only observed if its destination is unemployment. We do not observe earnings, or any other job characteristic, when people leave the unemployment registrar for employment. Furthermore, the potential period of observing programme effects cannot be longer than 15 months, since our latest observation dates from March, 31, 1999. ${ }^{25}$ In that sense the analysis will be restricted to the short run effects of the ALMP. Having in mind the above qualifications, the effect of the programmes will be measured in terms of changes in the average probabilities of employment (measured as explained above) in the first labour market caused by the programme. ${ }^{26}$ There is an issue of when to measure the effects. Here, they are measured after the programme begins. Hence, if somebody leaves a programme early in order to take up a job, this will influence our measure of effectiveness of the programme in a positive way. Such a measure could be disputed when one believes that being in the programme is a 'good thing' per se, but we concentrate solely on the success in the labour market. The alternative of measuring the effects after the programme ends entails an endogeneity problem (at least in the short run), because successful participants will leave their programme earlier.

Table 8 gives descriptive statistics for the outcome variables employed as well as for not being registered as unemployed. These outcomes are measured either with respect to a particular distance in time to the start of the respective programme (here one year), or at a particular day in calendar time (here the last day observed in the data, i.e. March, 31, 1999). Table 8 shows that it

\footnotetext{
${ }^{24}$ The internal time for the administration to make the data accessible to outsiders differs substantially between the unemployment registrar data and the data coming from the social security system.

25 Note that this paper has been written in early 2000. Hence, the time lag between our latest observation and the communication of results is exceptionally short for a microeconometric study.

26 The time in a programme is not considered as employment in that sense.
} 
does not really matter what concept of time is used. However, the distinction with respect to employment or unemployment matters, because the outflows into the remaining state out-of-thelabour-force differ across programmes. In the following employment will be used as outcome variable, because from an economic point of view we consider it to be the more relevant concept. ${ }^{27}$

Table 8: Mean outcomes after the begin of the programmes in \%-points

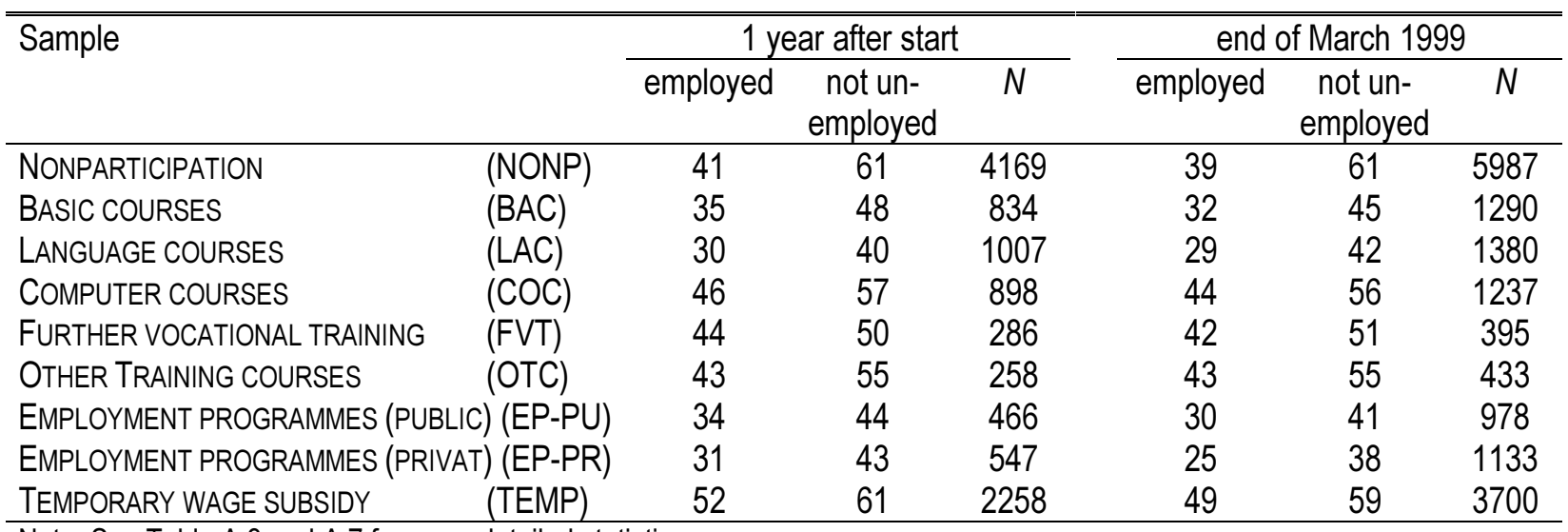

Note: See Table A.3 and A.7 for more detailed statistics.

In addition to the means of the outcome variables Table 8 contains the number of available observations. Note that this number is lower when the outcome is measured one year after the start of the programme. The difference is the number of participants in programmes that start after March 1998. Nevertheless, the remaining sample appears to be sufficiently large to conduct reliable inference.

\subsection{Mean effects}

Table 9 presents the results for the changes in the employment rates due to the programme one year after the individual programme participation starts. The corresponding effects measured at the end of March 1999 are very similar (see Table B.1 in Appendix B) and will be omitted in the following discussion.

\footnotetext{
27 Note that the employment rates given in Table 7 do not exactly equal the ones given in Table 1 . Table 7 , but not Table 1, is based on the subsample restricted by the common support requirement. However, all differences are smaller than two percentage points, most of them are not visible at all.
} 
The upper part of Table 9 displays the mean effects of the programmes on their respective participants, whereas the lower part gives the estimated average effect for a person randomly selected from the population. The entries in the main diagonal show the employment rates in the nine groups in percentage points. The programme effects are off the main diagonals. ${ }^{28} \mathrm{~A}$ positive number indicates that the effect of the programme shown in the row compared to the programme appearing in the column is an additional amount of XX\%-points of employment. In the upper part of the table, this effect is valid for the population participating in the programme appearing in the rows of the table. For example, the entry for the programme in the fifth row (FURTHER VOCATIONAL TRAINING) and the programme in the eighth column (EMPLOYMENT PROGRAMME, PRIVATE) should be read as follows: 'for the population participating in FURTHER VOCATIONAL TRAINING, VOCATIONAL TRAINING increases the probability of being employed one year after the programme on average by $13.7 \%$-points compared to that population being in an EMPLOYMENT PROGRAMME (PRIVATE).' The effects presented in the lower part of the table have a corresponding interpretation, but they do not refer to a specific subpopulation. Note these effects are symmetric $\left(\gamma_{0}^{m, l}=-\gamma_{0}^{l, m}\right)$. The last row in the upper and lower part of Table 9 show the composite effects as defined in section 3. The table contains only an entry for a pair-wise effect when the estimate is statistically significant at the $10 \%$ level.

The results for the respective participants in the programmes (upper part of Table 9) indicate that TEMPORARY WAGE SUBSIDY is superior to almost all the other programmes. The mean gain is between about $6 \%$ and 22\%-points. In particular TEMPORARY WAGE SUBSIDY is the only programme that dominates NONPARTICIPATION $(+6 \%)$. Summarising all the pair-wise effects as well as the composite effects we get a clear indication that TEMPORARY WAGE SUBSIDY is the most effective programme, whereas EMPLOYMENT PROGRAMMES as well as BASIC and LANGUAGE COURSES have negative effects. The remaining courses are somewhat intermediate.

\footnotetext{
${ }^{28}$ To ease reading and writing in most cases we will call NONPARTICIPATION a programme.
} 
Table 9: Average effects measured as difference in employment rates one year after start of programme in \%-points

\begin{tabular}{|c|c|c|c|c|c|c|c|c|c|}
\hline \multirow{2}{*}{$m^{l}$} & \multirow[t]{2}{*}{ Nonpart. } & \multirow[t]{2}{*}{$\begin{array}{l}\text { basic } \\
\text { courses }\end{array}$} & \multirow[t]{2}{*}{$\begin{array}{l}\text { language } \\
\text { courses }\end{array}$} & \multirow[t]{2}{*}{$\begin{array}{c}\text { computer } \\
\text { courses }\end{array}$} & \multirow[t]{2}{*}{$\begin{array}{l}\text { vocat. } \\
\text { training }\end{array}$} & \multirow[t]{2}{*}{$\begin{array}{l}\text { other } \\
\text { training }\end{array}$} & \multicolumn{2}{|c|}{$\begin{array}{l}\text { employment } \\
\text { programme }\end{array}$} & \multirow{2}{*}{$\begin{array}{c}\text { temporary } \\
\text { wage } \\
\text { subsidy }\end{array}$} \\
\hline & & & & & & & public & private & \\
\hline \multicolumn{10}{|c|}{ average effect for participants in programme $\left(\theta_{0}^{m, l}\right)$} \\
\hline NONP & 42 & 10.4 & & & & & 8.3 & 9.2 & -7.1 \\
\hline BAC & -10.5 & 36 & & & & -18.4 & & & -14.8 \\
\hline LAC & -8.7 & & 31 & & -15.6 & -16.1 & 9.1 & & -20.2 \\
\hline $\mathrm{COC}$ & -4.8 & 11.1 & & 46 & & -14.1 & & & -9.1 \\
\hline FVT & & 13.0 & & & 44 & & 13.8 & 13.8 & -11.9 \\
\hline OTC & & 8.9 & & & & 43 & 12.7 & & -7.9 \\
\hline TE-PU & -6.6 & & & & -10.6 & -14.3 & 33 & & -15.1 \\
\hline TE-PR & -7.9 & & & & & -15.3 & & 31 & -22.6 \\
\hline TEMP & 5.8 & 17.4 & 10.9 & 7.4 & & & 17.5 & 14.7 & 52 \\
\hline Composite & 1.5 & -8.8 & -9.7 & -2.8 & 1.1 & 0.7 & -7.8 & -8.8 & 9.0 \\
\hline \multicolumn{10}{|c|}{ average effect $\left(\gamma_{0}^{m, l}\right)$} \\
\hline NONP & 42 & 10.1 & 6.0 & & & & 9.9 & 8.5 & -7.6 \\
\hline BAC & -10.1 & 36 & & -6.5 & -8.8 & -16.7 & & & -17.7 \\
\hline LAC & -6.0 & & 31 & & & -12.5 & & & -13.5 \\
\hline $\mathrm{COC}$ & & 6.5 & & 46 & & -10.2 & & & -11.2 \\
\hline FVT & & 8.8 & & & 44 & & 8.6 & & -8.8 \\
\hline ОTC & & 16.7 & 12.5 & 10.2 & & 43 & 16.5 & 15.1 & \\
\hline TE-PU & -9.9 & & & & -8.6 & -16.5 & 33 & & -17.4 \\
\hline TE-PR & -8.5 & & & & & -15.1 & & 31 & -16.1 \\
\hline TEMP & 7.6 & 17.7 & 13.5 & 11.2 & 8.8 & & 17.4 & 16.1 & 52 \\
\hline Composite & -1.1 & -13.1 & -13.1 & -5.6 & -0.9 & 0.5 & -12.0 & -12.8 & 10.5 \\
\hline
\end{tabular}

It might appear strange that a programme can harm individual employment chances. However, assume that the programmes themselves do not change the employment chances directly. ${ }^{29} \mathrm{Nev}$ ertheless, an immediate indirect effect of all programmes will be a reduction in job search activities compared to nonparticipants. Furthermore, participants may receive fewer job offers from the labour office. In this case we should expect an initial negative effect from any kind of participation in a programme, but in the longer run the direct effect of a successful programme needs to overcompensate for this initial fall (note that we measure the effects from the start of the programme). Indeed the dynamics of the effects that will be presented below exactly show that pattern.

${ }^{29}$ They could of course decrease the employment chances if there is negative signalling, but ignore this for the sake of the argument. 
The population effects contained in the lower panel by and large confirm the results that appear in the upper panel of Table $9 .^{30}$ This is not according to our expectations, because a well targeted programme could be expected to be more efficient for its participants than for participants in other programmes or nonparticipants. However, comparing corresponding numbers above and below the main diagonal in the upper panel of Table 9 for the different groups of participants, no systematic pattern appears. In particular the effects of the programmes do not appear to be consistently more positive for its participants than for other groups of the population. This result suggests that selection into the programmes appears not to be correlated with realised gains from the programmes. This rises the question whether the allocation of individuals to specific parts of the active labour market policies could be improved in the future.

The following figures show the dynamics of the effects by showing their development over time after the start of the programme. Figure 2 presents the composite effects of each programme for its participants. A value larger than zero indicates that the programme would actually increase employment chances compared to be being randomly allocated to one of the other programmes (see section 3 for the exact definition). Note that the sample sizes decrease the longer the distance from the start, since the last observation is March, 31, 1999, and the programmes may start until Jan, 31, 1999. The numbers show again that most programmes start in the first quarter of 1998, so that the sample size is potentially large enough to estimate the effects for about one year after the start of a programme with sufficient precision (see Table A.6 in Appendix A.5).

Considering the relative positions of the respective curves, the line for NONPARTICIPATION reveals the expected profile: In the beginning it is positive and increasing, but then it starts to decline as participants leave their respective programmes and increase their job search activities. The composite effects for all the programmes show the reverse shape except for TEMPORARY WAGE SUBSIDY where the effect is steadily increasing. EMPLOYMENT PROGRAMMES as well as LANGUAGE and BASIC COURSES show only a very limited improvement over time. The composite effects of FURTHER VOCATIONAL TRAINING, OTHER TRAINING COURSES, and COMPUTER COURSES increase over time, but not sufficiently to reveal a substantial positive effect.

\footnotetext{
${ }^{30}$ The term population refers to the population defined by selection rules explained before.
} 
Figure 2: Composite effects for respective participants

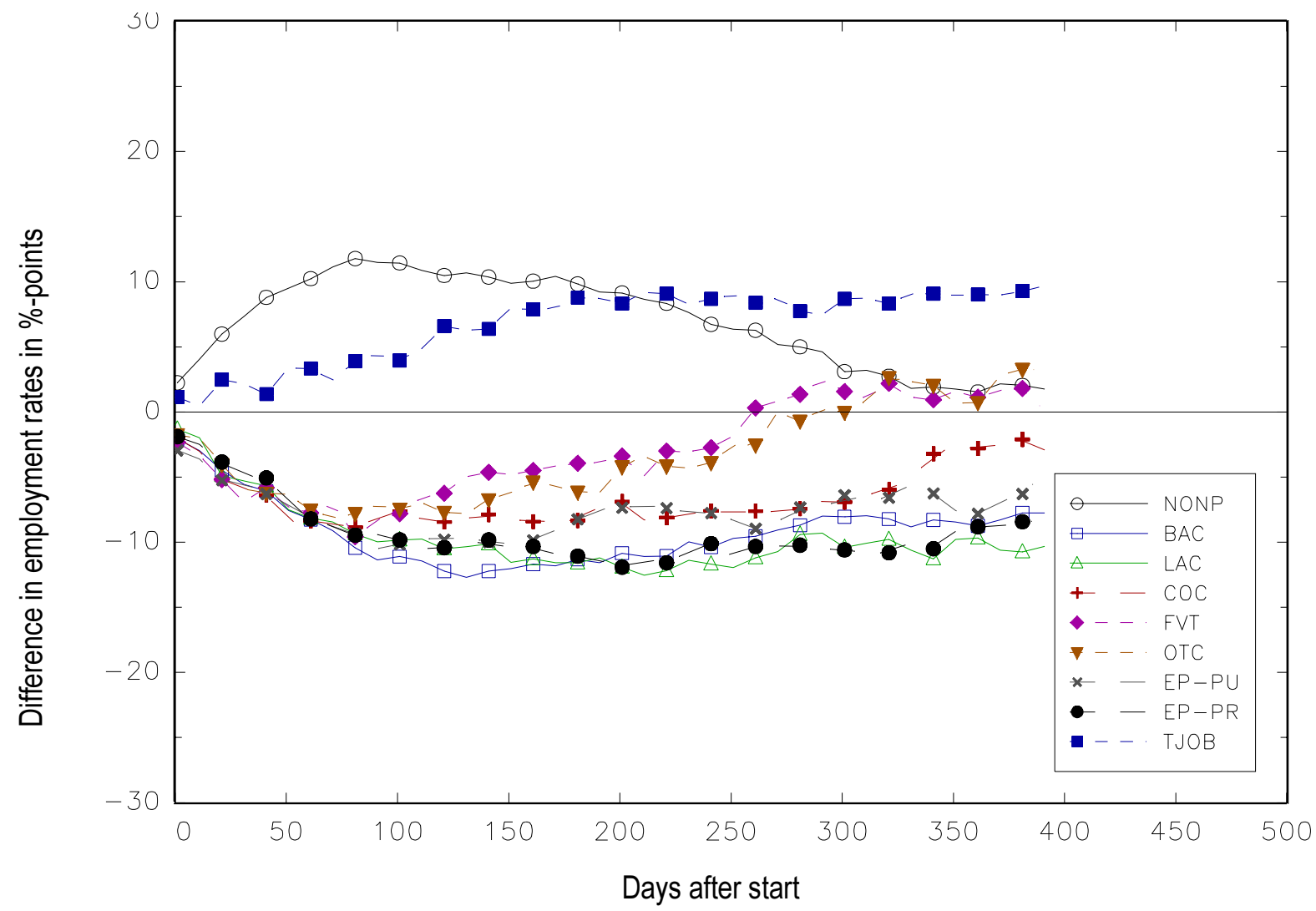

Note: $\quad$ NONP: Nonparticipation, BAC: Basic training course; LAC: Language course; COC: Computer course; FVT: Further vocational training; OTC: Other training course; EP-PU: Employment programme (public); EP-PR: Employment programme (private); TJOB: Temporary wage subsidy.

All estimated effects are reported (independent of their significance level).

Figures 3 to 8 give more insights for the particular programmes using direct comparisons of the programmes with each other and with NONPARTICIPATION. ${ }^{31}$

Figure 3 displays the estimates of the effects of FURTHER VOCATIONAL TRAINING for participants in VOCATIONAL TRAINING. A line above zero indicates that FURTHER VOCATIONAL TRAINING has a positive employment effect relative to the programme associated with that particular line. Only effects significant at the $5 \%$ level are displayed.

With respect to the comparison with NONPARTICIPATION the same pattern appears as before. Initially, there is a drop leading to a large negative effect that is associated with the time in the programme. After about three months there is a reversal and after about 250 days it cannot be distin-

${ }^{31}$ For the sake of brevity we concentrate only on five different programmes. Corresponding results for the other programmes can be found in Appendix B. 
guished statistically from zero anymore (at the 5\% significance level). The time horizon might be too short to observe a statistically significant positive effect.

Such a reversal does not appear for the negative effect of FVT in the comparison to TEMPORARY WAGE SUBSIDY. The effect remains negative throughout. Taken literally, this means that the participants in FVT would have been better off if they would have participated in TEMPORARY WAGE SUBSIDY instead. Comparisons with EMPLOYMENT PROGRAMMES as well as with BASIC COURSES show that these programmes are all dominated by FUTHER VOCATIONAL TRAINING after about three months.

Figure 3: Average effects of FURTHER VOCATIONAL TRAINING for participants in FVT

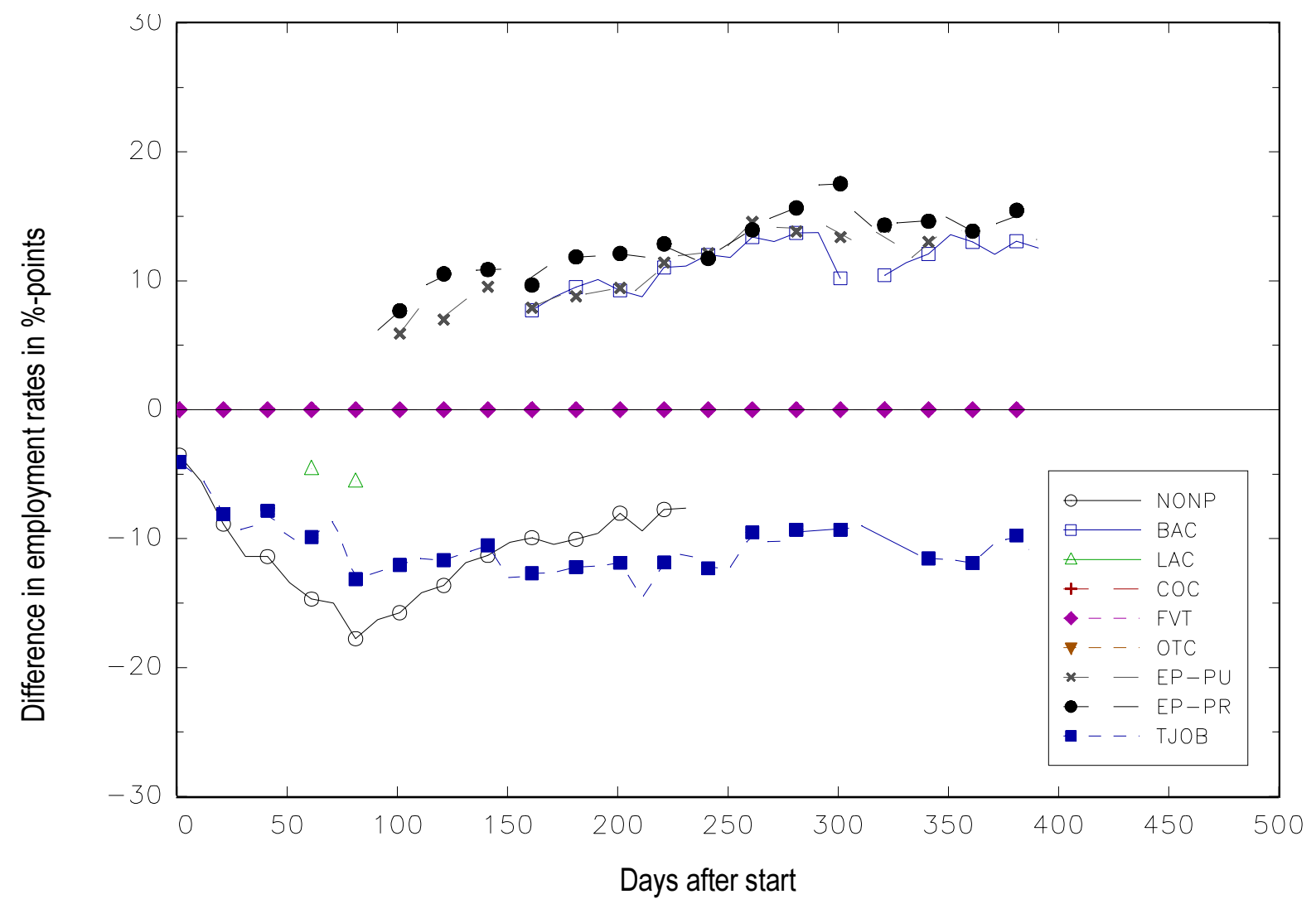

Note: $\quad$ NONP: Nonparticipation, BAC: Basic training course; LAC: Language course; COC: Computer course; FVT: Further vocational training; OTC: Other training course; EP-PU: Employment programme (public); EP-PR: Employment programme (private); TJOB: Temporary wage subsidy.

Only estimated effects that are significant at the $5 \%$ level are reported.

Whereas the results for OTHER TRAINING COURSES (Figure B.2 in Appendix B) are similar to those for FVT, the results for BASIC TRAINING (Figure 4) as well as for LANGUAGE COURSES (Figure B.1 
in Appendix B) differ substantially from the results for FVT. In both cases we observe similar dynamic patterns: With respect to NONPARTICIPATION the initial drop is somewhat reversed over time, but remains significantly negative. They are always dominated by TEMPORARY WAGE SUBSIDY and after some time they are also dominated by other training courses (FVT, OTC).

Figure 4: Average effects of BASIC COURSES for participants in BAC

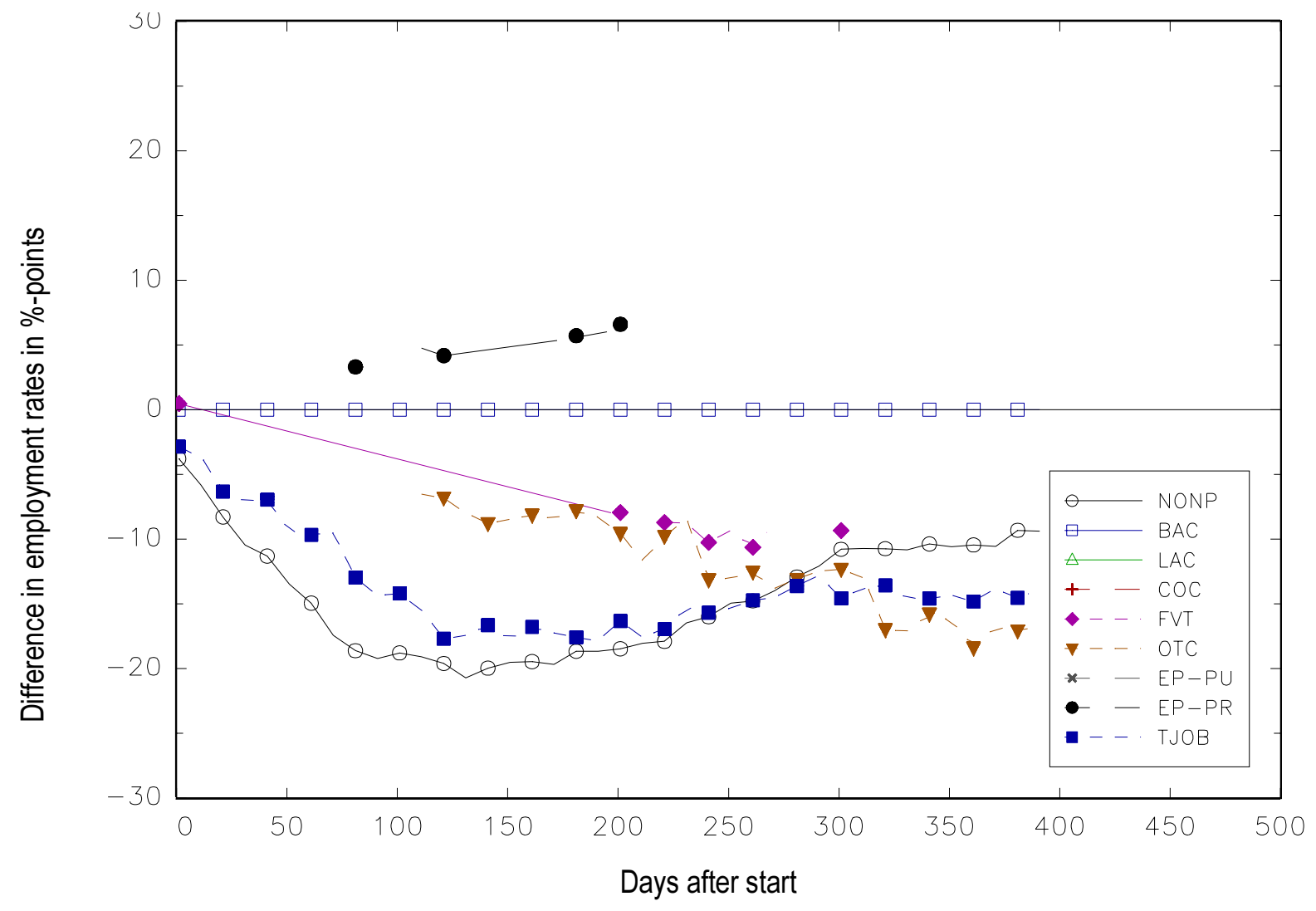

Note: $\quad$ NONP: Nonparticipation, BAC: Basic training course; LAC: Language course; COC: Computer course; FVT: Further vocational training; OTC: Other training course; EP-PU: Employment programme (public); EP-PR: Employment programme (private); TJOB: Temporary wage subsidy.

Only estimated effects that are significant at the $5 \%$ level are reported.

COMPUTER COURSES are somewhat in the middle between FVT, OTC and BAC, LAC, as can be seen from Figure 5. They are permanently dominated by TEMPORARY WAGE SUBSIDY, whereas the negative effect compared to nonparticipation disappears towards the end. 


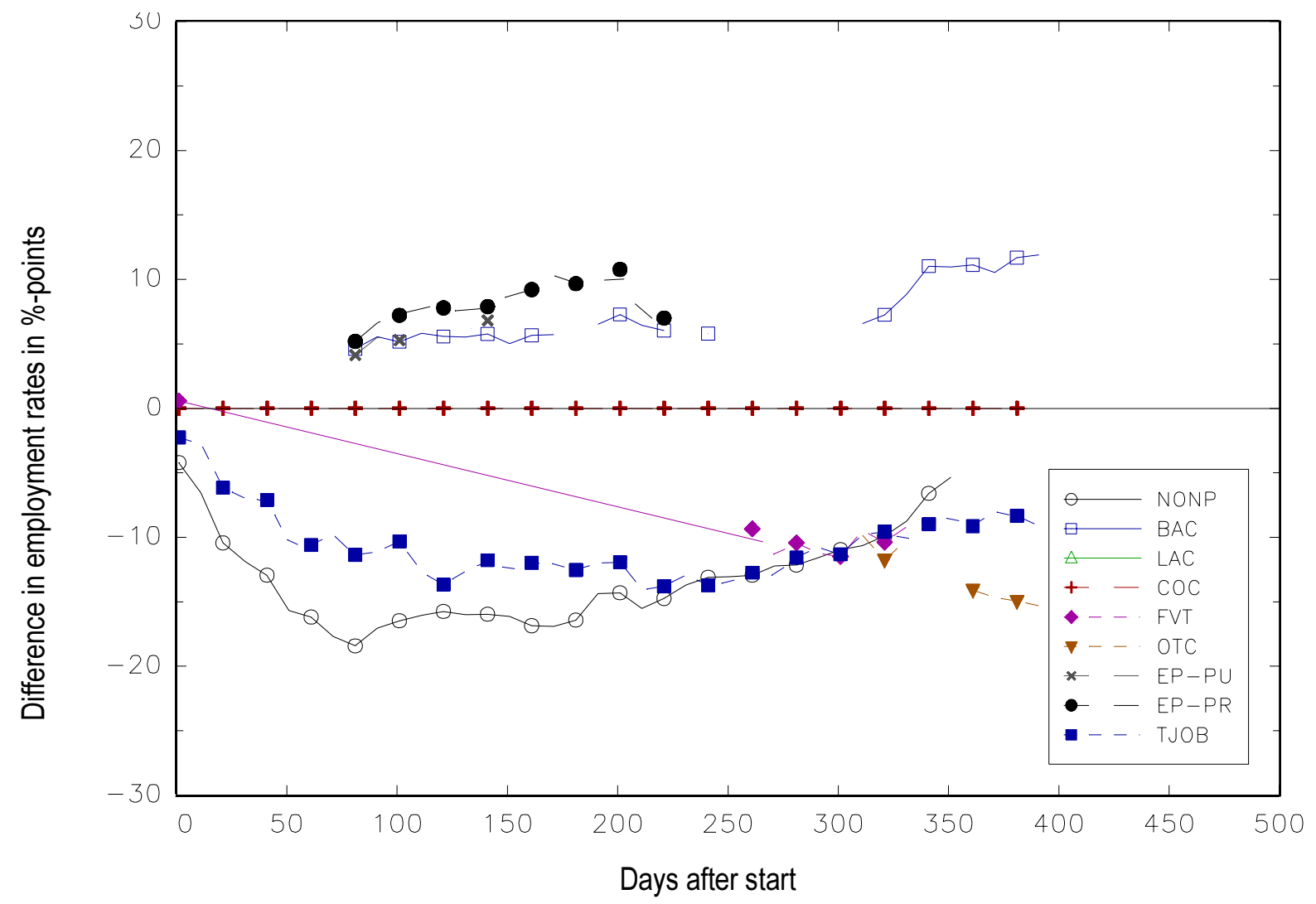

Note: $\quad$ NONP: Nonparticipation, BAC: Basic training course; LAC: Language course; COC: Computer course; FVT: Further vocational training; OTC: Other training course; EP-PU: Employment programme (public); EP-PR: Employment programme (private); TJOB: Temporary wage subsidy.

Only estimated effects that are significant at the $5 \%$ level are reported.

Figure 6 shows the estimates of pair-wise effects for EMPLOYMENT PROGRAMMES (PUBLIC). The previous result that EP-PU is not a successful programme is confirmed: it is dominated throughout by NONPARTICIPATION and TEMPORARY WAGE SUBSIDY. The negative effect with respect to NONPARTICIPATION increases initially as before. Again, after about three months there is a reversal. Note that this happens well before the average programme duration of about 150 days. Although the effect decreases continuously afterwards it remains significantly negative after about one year. We conjecture that it is not very likely that it will become positive in the near future.

After about 250 days EP-PU is also dominated by FURTHER VOCATIONAL TRAINING and OTHER TRAINING, which have an average programme duration of about half of that of EP-PU. EP-PU is the only programme that has no positive effect at all. The results for the second group of EMPLOYMENT PROGRAMMES (PRIVATE) look very similar to the ones for EP-PU and lead basically to the same conclusions (see Figure B.3 in Appendix B). 
Figure 6: Average effects of EMPLOYMENT PROGRAMME (PUBLIC) for participants in EP-PU

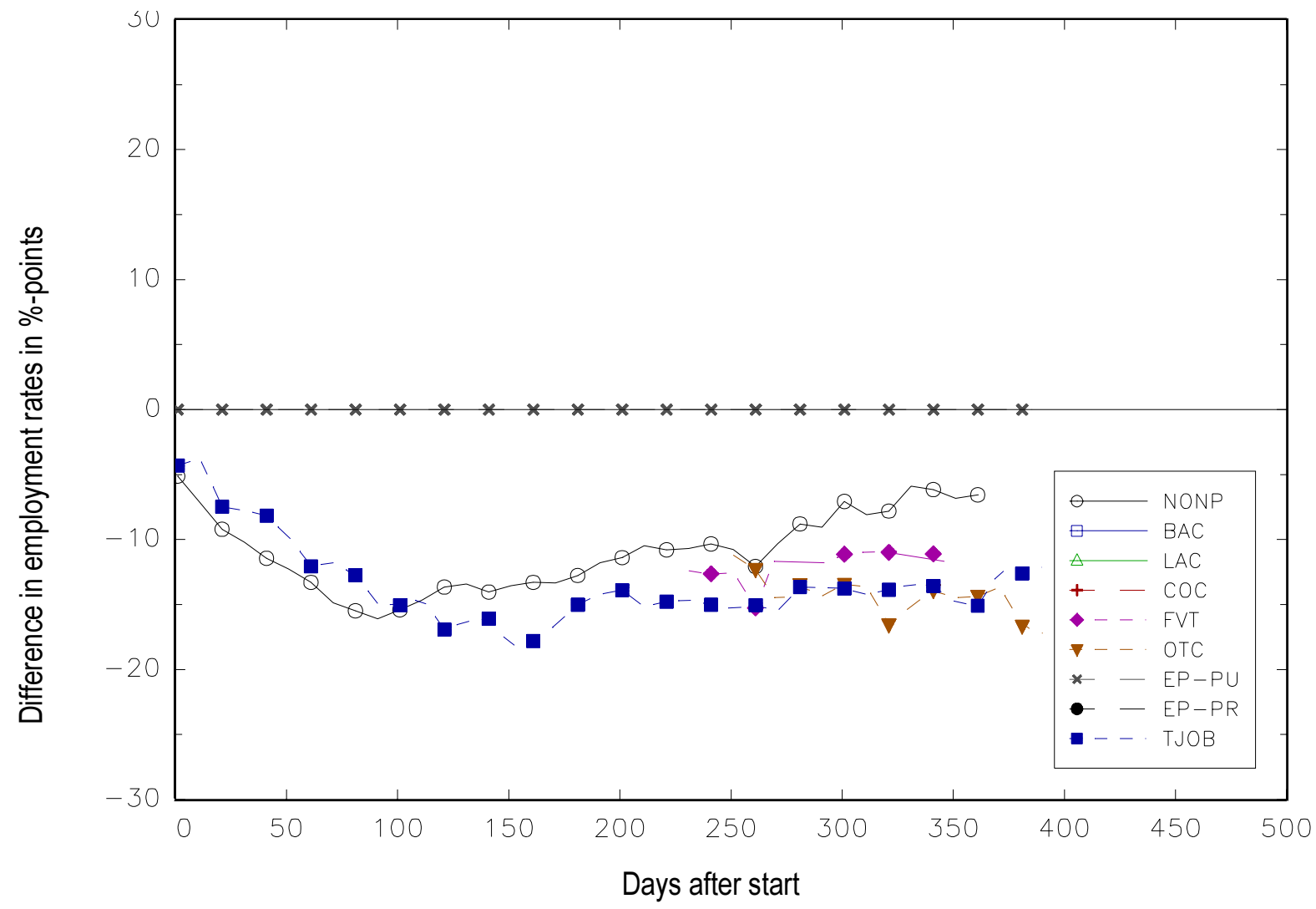

Note: $\quad$ NONP: Nonparticipation, BAC: Basic training course; LAC: Language course; COC: Computer course; FVT: Further vocational training; OTC: Other training course; EP-PU: Employment programme (public); EP-PR: Employment programme (private); TJOB: Temporary wage subsidy.

Only estimated effects that are significant at the $5 \%$ level are reported.

Finally, Figure 7 gives the same type of results for TEMPORARY WAGE SUBSIDY. It dominates all other programmes almost from the start. For most programmes this picture persists over time except for OTHER TRAINING and FURTHER VOCATIONAL TRAINING. For those two programmes the initial negative effect reverses after about half a year and becomes insignificant some time later. With respect to NONPARTICIPATION the familiar pattern appears but in this case we find a positive effect for TEMPORARY WAGE SUBSIDY after about nine months. 


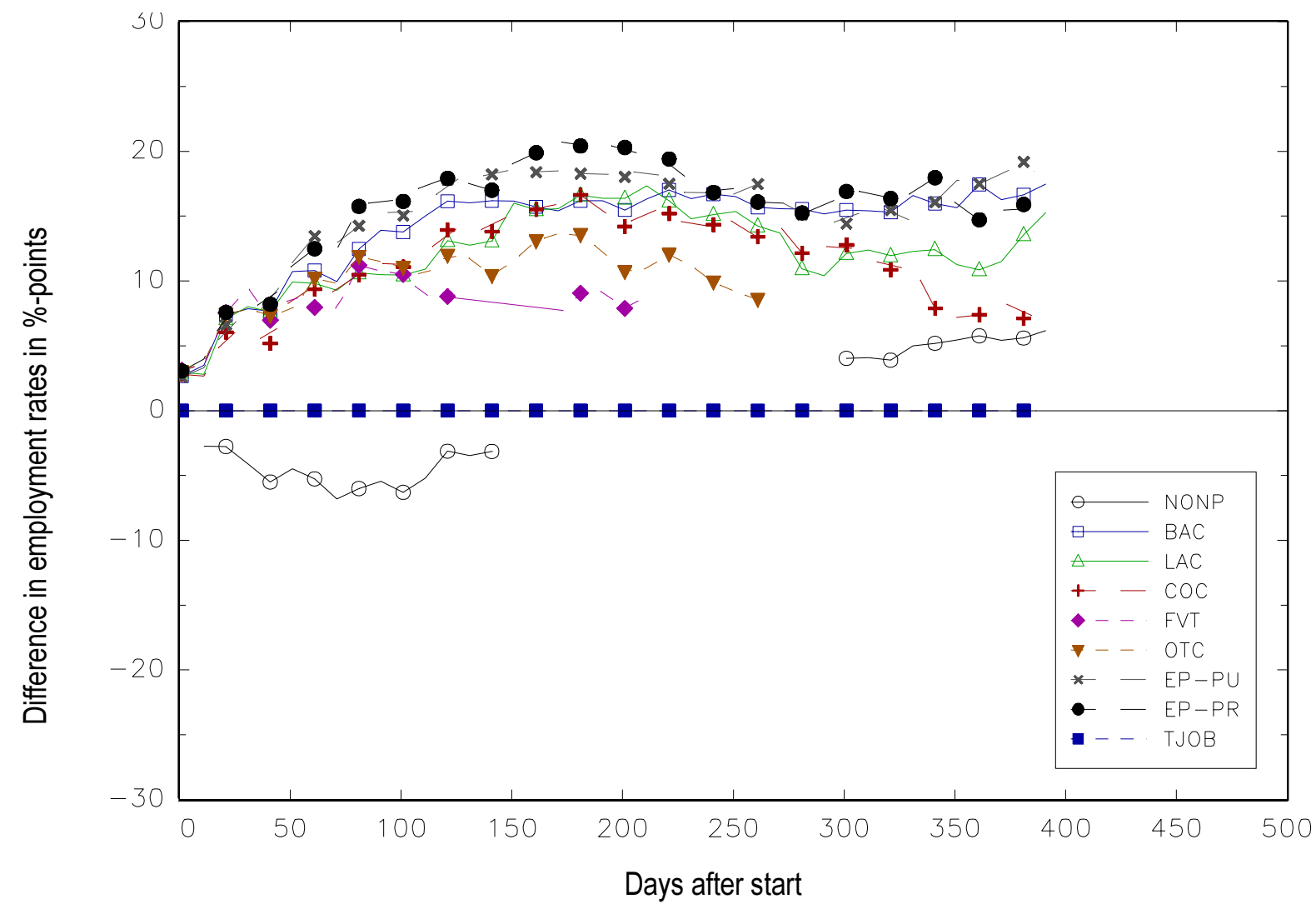

Note: $\quad$ NONP: Nonparticipation, BAC: Basic training course; LAC: Language course; COC: Computer course; FVT: Further vocational training; OTC: Other training course; EP-PU: Employment programme (public); EP-PR: Employment programme (private); TJOB: Temporary wage subsidy.

Only estimated effects that are significant at the $5 \%$ level are reported.

Figure 8 provides yet another perspective on the effectiveness of the programmes. It compares the state of nonparticipation as reference state with all programmes. In this case all effects relative to NONPARTICIPATION are estimated for the entire population. Note that a line above zero indicates that NONPARTICIPATION would actually increase employment compared to the programme indicated by this particular line. Figure 8 again confirms the previous results. For all programmes we find initially a negative effect compared to NONPARTICIPATION. For TEMPORARY WAGE SUBSIDY this effect disappears after about four months and becomes positive after about eight months. We observe a similar, but somewhat slower reversal for FURTHER VOCATIONAL TRAINING, OTHER TRAINING COURSES, and with a further delay also for COMPUTER COURSES. However, in all these cases the effect does not become significantly positive. The dynamics of the effects of LANGUAGE COURSES, BASIC COURSES as well as EMPLOYMENT PROGRAMMES show a similar shape, but they stay significantly negative until the end of the observation period. 


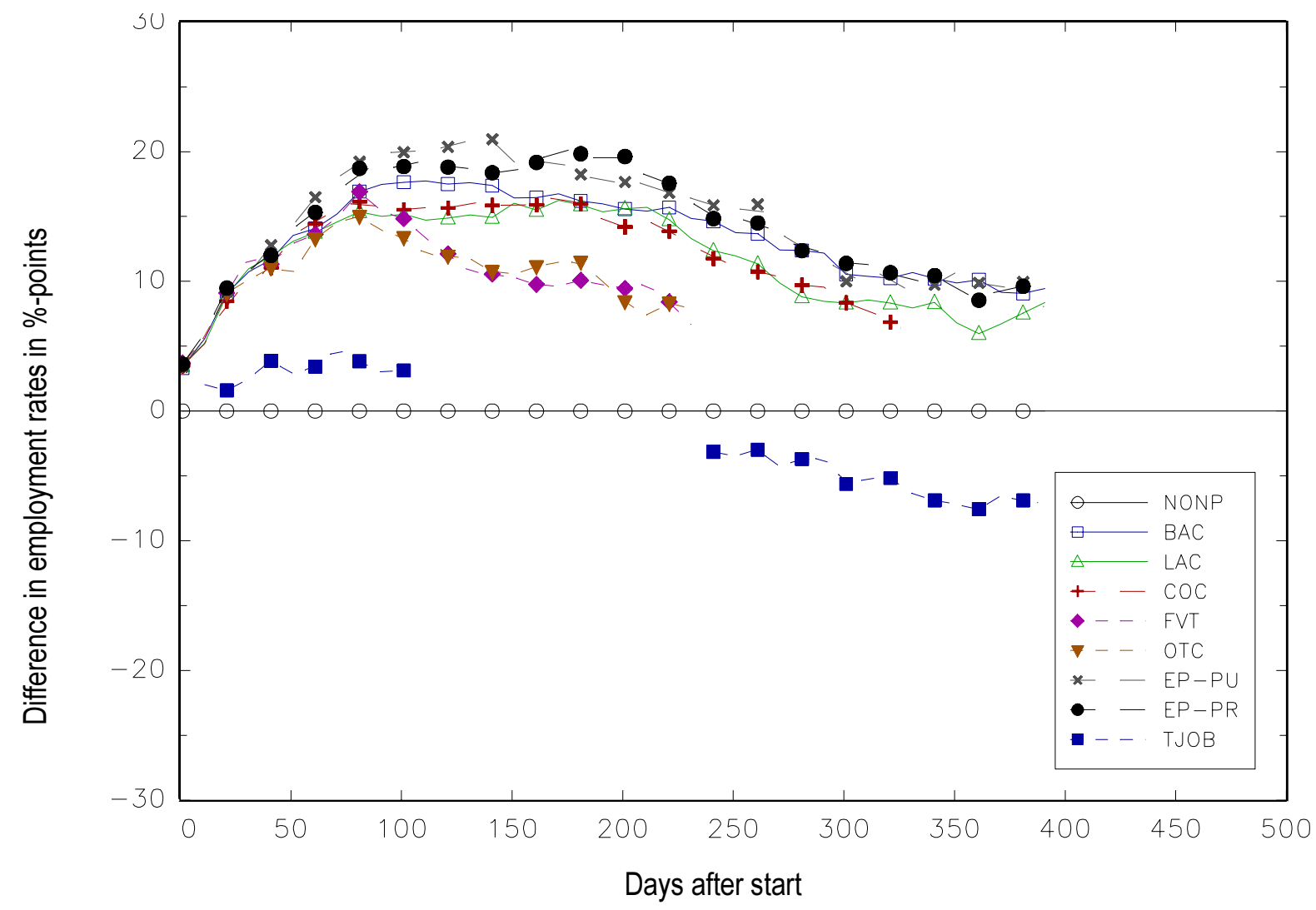

Note: $\quad$ NONP: Nonparticipation, BAC: Basic training course; LAC: Language course; COC: Computer course; FVT: Further vocational training; OTC: Other training course; EP-PU: Employment programme (public); EP-PR: Employment programme (private); TJOB: Temporary wage subsidy.

Only estimated effects that are significant at the $5 \%$ level are reported.

\subsection{Heterogeneity of the effects}

The previous section has shown that there is considerable heterogeneity with respect to the effects of the different programmes. In this section we investigate the question whether different groups of potential participants show markedly heterogeneous effects. We perform this analysis by estimating the various effects in different strata of the sample. To avoid flooding the reader with results that tell more or less the same story, we will only show the dynamic developments of the composite effects. Figures 9 to 11 show the results according to gender, nationality, and duration of the unemployment spell before training. The corresponding comparisons to NONPARTICIPATION are referred to Figures B.4 to B.6 in Appendix B.2. 
Let us first consider differences by gender as depicted by Figures $9 \mathrm{a}$ and $9 \mathrm{~b} .{ }^{32}$ There appear to be mainly two interesting deviations from the overall mean effects. For men it seems that the effect of OTHER COURSES is increasing rapidly towards the end of the observation period. Due to OTC being a residual category, and due to the fact that the number of observations falls below 100 in this region, we will refrain from giving that effect any interpretation. The more interesting deviation concerns the EMPLOYMENT PROGRAMMES (PUBLIC) for women. Instead of having the negative result discussed above, EP-PU appears to have an effect like the more successful training courses (VTC, COC, OTC). This conclusion is also confirmed by considering the other more specific plots have been omitted from this paper for the sake of brevity. Interestingly enough, this effect changes only for EP-PU, but not for EP-PR. For the PRIVATE EMPLOYMENT PROGRAMMES the effects remain as negative as for men and women together.

Figures 10a and 10b show the heterogeneity of the results according to nationality (Swiss or nonSwiss). ${ }^{33}$ Several interesting differences appear: First, a puzzling result is that LANGUAGE COURSES appear to have an extremely negative effect for the non-Swiss population. This is seriously at odds with our priors, so that doubts are raised whether the factors related to the participation of this population like the year of entering the social security system, mother tongue, type of work permit, and knowledge of language, are really sufficiently controlled for in the estimation of the balancing scores.

Second, again for the non-Swiss population we find larger positive effects of TEMPORARY WAGE SUBSIDY and COMPUTER COURSES compared to the Swiss population. This might be explained by the hypothesis that only foreigners with very good prospects are admitted to computer courses. However, we did not test whether these differences are significant.

\footnotetext{
${ }^{32}$ See also Figures B.4a and B.4b in Appendix B.2.

33 See also Figures B.5a and B.5b in Appendix B.2.
} 
Figure 9: Effect heterogeneity with respect to gender

Figure 9a: Composite effects for men

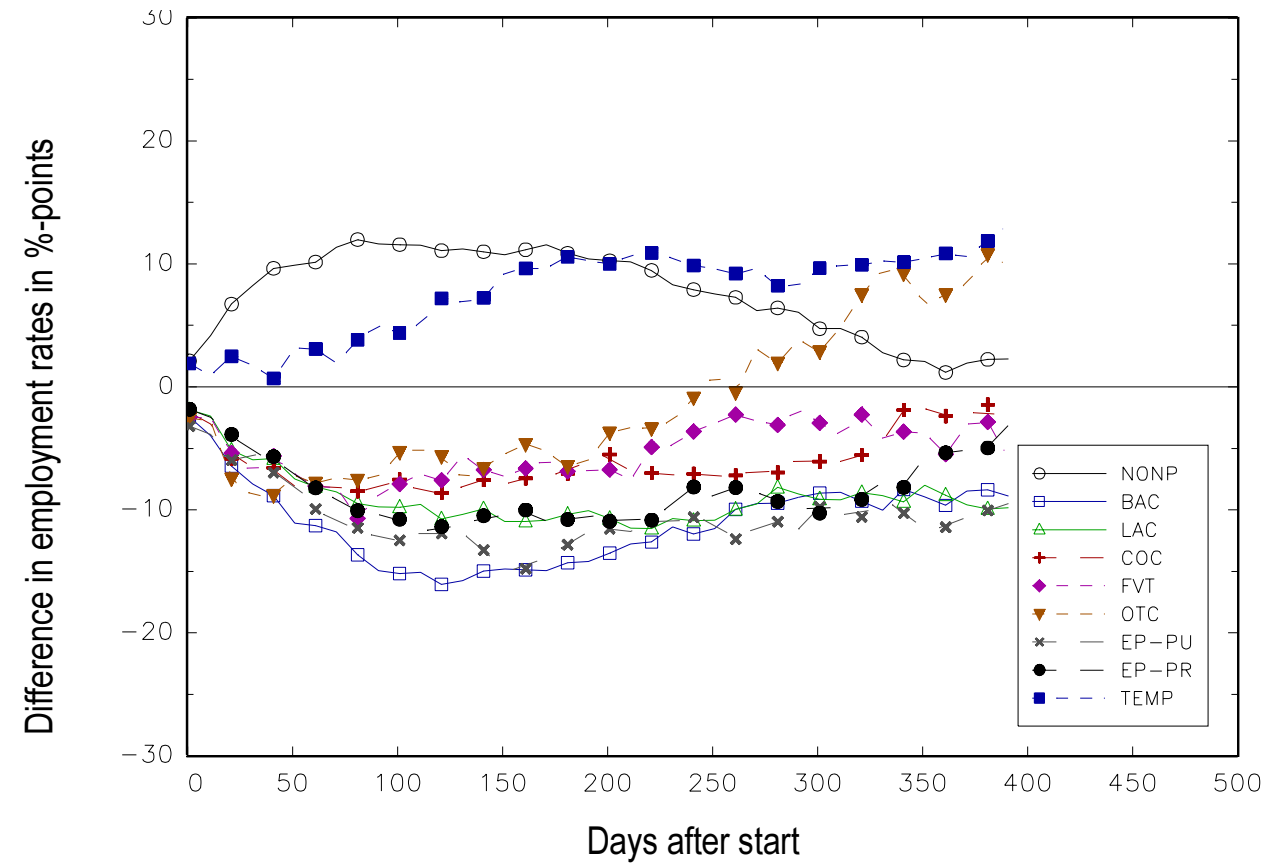

Note: Number of observation at day 181 / 361: 8117 / 5402. See also note below Figure 2.

Figure 9b: Composite effects for women

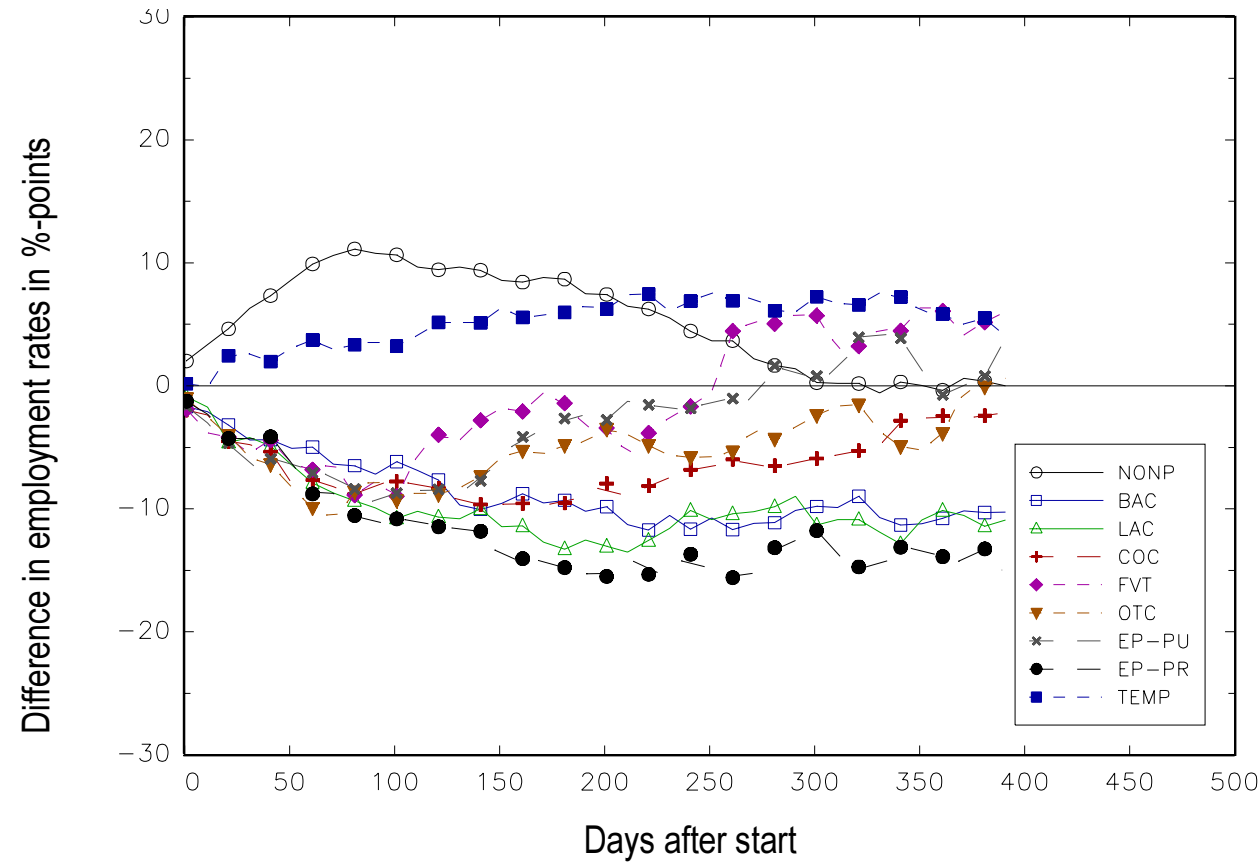

Note: Number of observation at day 181 / 361: 5568 / 3751. See also note below Figure 2 . 
Figure 10: Effect heterogeneity with respect to nationality

Figure 10a: Composite effects for Swiss citizens

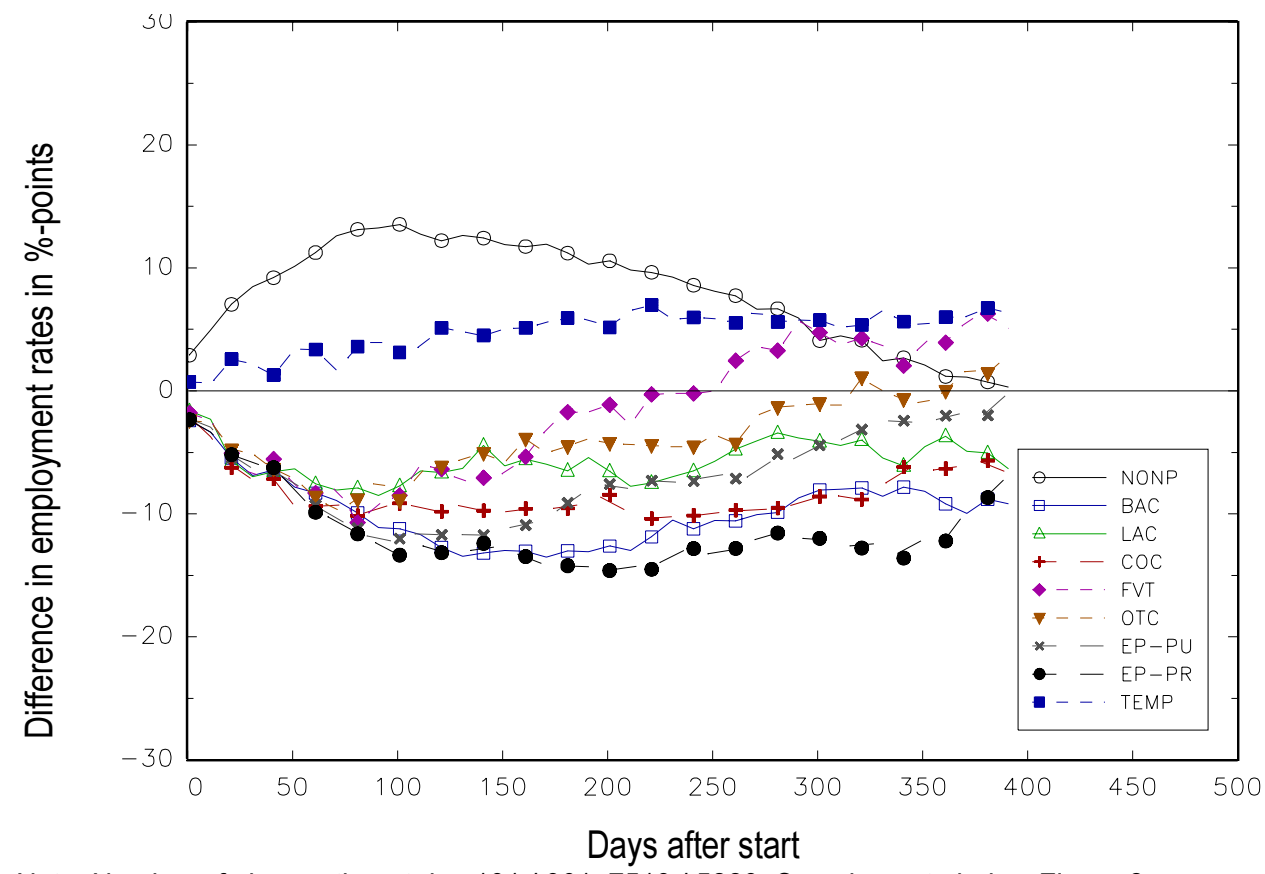

Note: Number of observation at day 181 / 361: 7513 / 5223. See also note below Figure 2 .

Figure 10b: Composite effects for foreigners

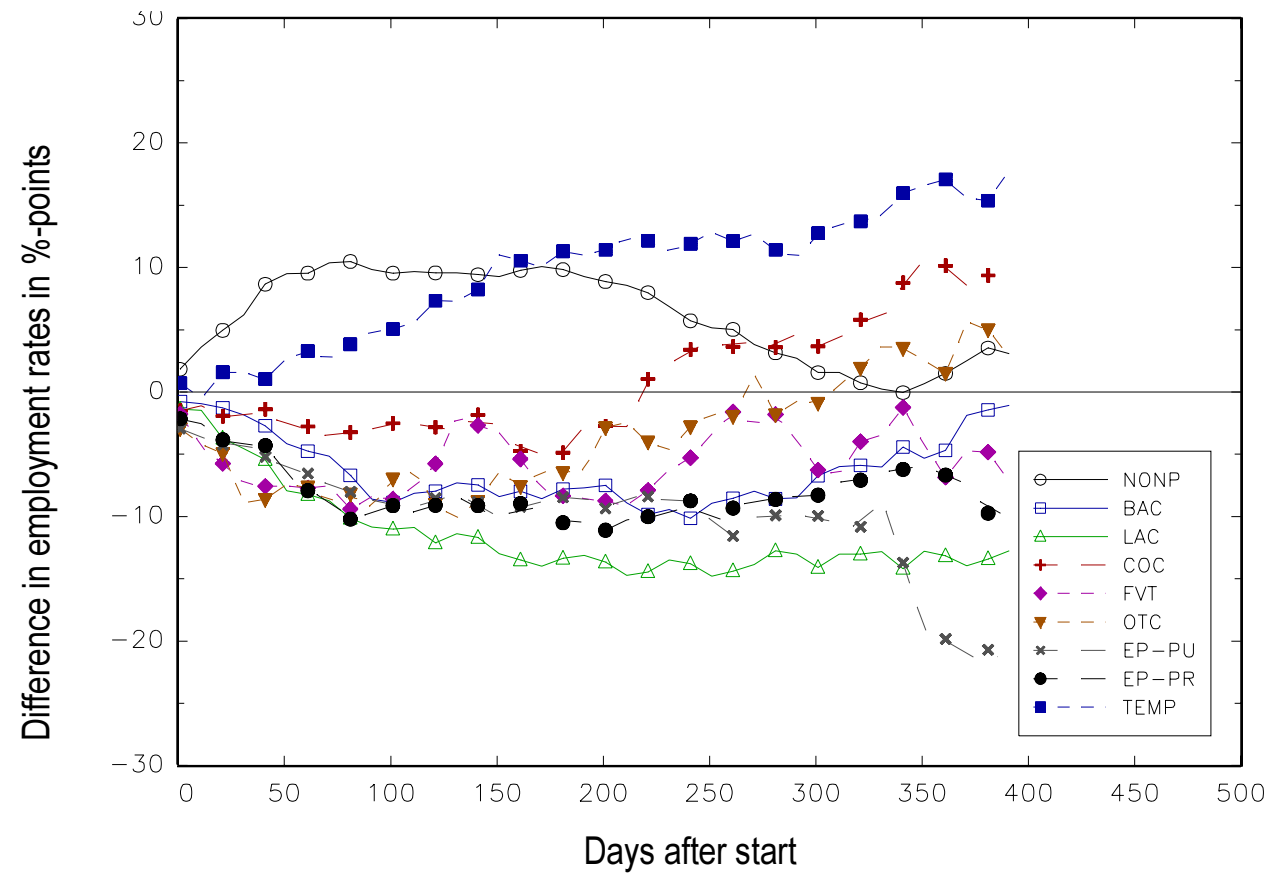

Note: Number of observation at day 181 / 361: 5768 / 3622. See also note below Figure 2 . 
Figure 11: Effect heterogeneity with respect to short term unemployment history

Figure 11a: Composite effects for people with less than 270 days of unemployment before start

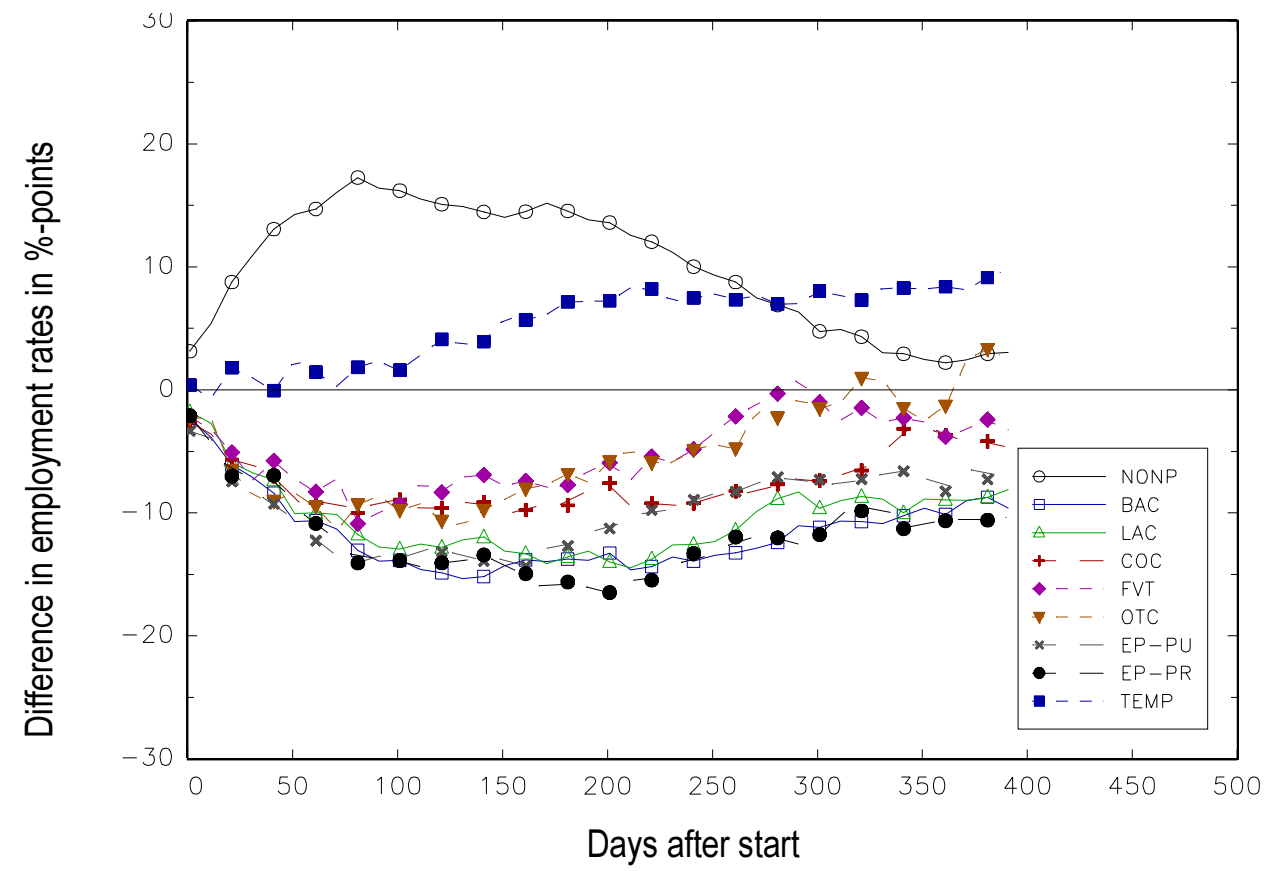

Note: Number of observation at day 181 / 361: 8889 / 7272 . See also note below Figure 2.

Figure 11b: Composite effects for people with more than 270 days of unemployment before start

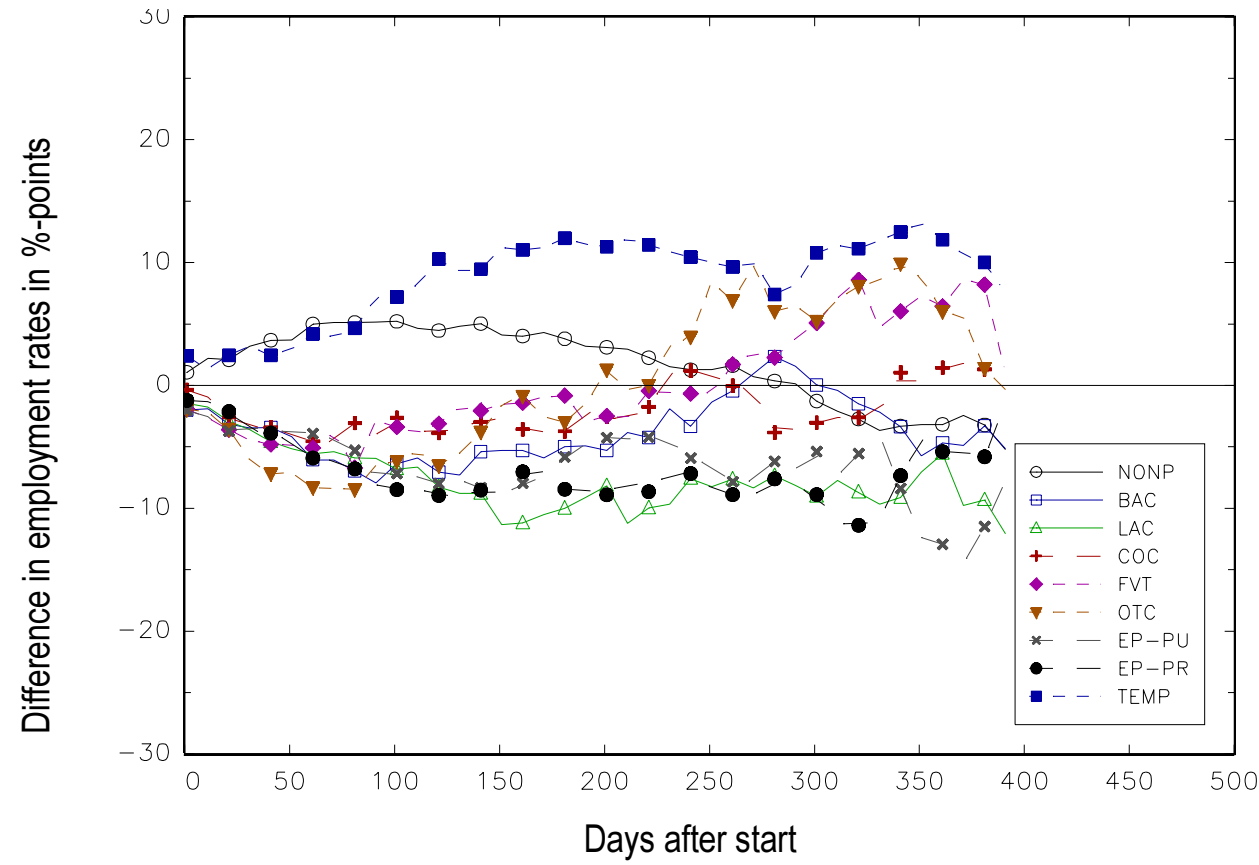

Note: Number of observation at day 181 / 361: 4165 / 1811. See also note below Figure 2. 
Figures 11a and $11 \mathrm{~b}$ show the composite results for two subgroups defined by the duration of the unemployment spell before the start of the programme (more or less than 270 days). ${ }^{34}$ For these groups a major difference appears with respect to shape and level of the effect of NONPARTICIPATION. For people with a short unemployment spell there is the familiar large negative initial effect. However, for those being in unemployment for more than 270 days before the programmes start the corresponding curve is much flatter. This different shape is of course transferred to the results for all other programmes. For example, for TEMPORARY WAGE SUBSIDY there is no initial negative effect. Furthermore, we find an earlier and larger significant positive effect. From an economic point of view these results are perfectly compatible with the following consideration: Assume that the average job offer arrival rate is higher in the beginning of an unemployment spell. One reason could be a sorting argument: The 'good' unemployed find jobs earlier, so in the population of long-term unemployed there are predominantly people with bad chances on the labour market. In that case the cost of any programme in terms of a reduction of the employment probability due to receiving less job offers during a programme are higher for the population that is at an early stage of their unemployment spell. Put differently, it appears to be a bad idea to 'lock away the unemployed in a programme' while they have a high probability of finding a job. After the returns to job search have fallen to a lower level, these indirect costs of programme participation are much lower.

\subsection{Sensitivity}

We checked our specification in several directions that could influence our overall conclusions. First, we used two more restricted versions of the covariance matrix of our multiple choice model: (i) only correlations between EMPLOYMENT PROGRAMMES and TEMPORARY WAGE SUBSIDY allowed; (ii) no correlations and homoscedasticity. Furthermore, the number of replications has also been reduced to only 20 . In all cases the final evaluation results are surprisingly robust to the different resulting balancing scores. The same holds true for matching with and without the variables that have been included in addition to the probabilities.

The second set of sensitivity checks relate to the outcome variables. When we use "not unemployed" instead of "employed" as outcome we obviously get somewhat different results in the comparison to NONPARTICIPATION because this group contains the largest share of unemployed

\footnotetext{
34 See also Figures B.6a and B.6b in Appendix B.2.
} 
who leave the labour force after being deregistered from the unemployment registrar. Therefore, using not unemployed as outcome variable makes NONPARTICIPATION the most successful strategy, whereas the relative effects between the other groups remain more or less the same. ${ }^{35}$

Changing the start of measurement from the begin of a programme to the end of a programme can have serious consequences for some results (at least in the short run) due to the already discussed endogeneity problem that is due to successful participants leaving the programme early towards employment. The most interesting changes appear with respect to the effect of the EMPLOYMENT PROGRAMMES (PRIVATE): After an initial positive (!) effect compared to NONPARTICIPATION for the first three months, we obtain a negative effect after some time. ${ }^{36}$ Note however, that in this case it is more difficult to obtain precise estimates because the number of observations is necessarily lower than in the standard case. Furthermore, since matching takes only account of start dates and not of end dates (because end dates are considered to be endogenous), these results may be influenced by business cycles as well as seasonal effects. Since we are in an upswing after 1997 we would expect an upward bias in the effects of the EMPLOYMENT PROGRAMMES, because the outcomes of the participants of the EMPLOYMENT PROGRAMME are measured considerably later than the outcomes of the nonparticipants.

In another sensitivity check the 'standard' results are compared to results that are based on calendar time instead of time counted from the start of a programme. For each line the mean is computed over all observations that already have started a programme. Therefore, these effects have a different interpretation because initially they contain observations shortly after the start of their programme. Over time more observations enter, but also the share of the 'older' (measured as distance from start) observations as well as the total number of observations increases. With these considerations in mind we find effects that are very similar to the ones already presented and lead therefore to the same conclusions. ${ }^{37}$

There may be the concerns that unemployed with only temporary permits might leave the unemployment register and remigrate to their home country. In that case we would observe them as being out-of-the- labour force. Another issue might be that we want to consider the effects only for the so-called full-time unemployed. Our results for the subsample of full-time unemployed who have either permanent permits or are Swiss citizens indicate however that the main conclu-

\footnotetext{
35 See Figures B.7a and B.7b in Appendix B.3.

36 See Figures B.8a and B.8b in Appendix B.3.

37 See Figures B.9a and B.9b in Appendix B.3.
} 
sions do not change for that subsample. The negative effects for the LANGUAGE COURSES are however somewhat smaller than for the full sample. ${ }^{38}$ The results for women in that subgroup do not substantially deviate from the general findings for women presented above. ${ }^{39}$

\subsection{Comparison with other Swiss evaluation studies}

The other econometric evaluation of the Swiss ALMP by Lalive, van Ours, and Zweimüller (2000) is part of the same research programme initiated by the Swiss government. Their data come from the same sources as ours. They restrict their sample to the inflows in unemployment between December 1997 and March 1998 because their econometric evaluation approach is based on duration models. Our results are based on the stock of those being unemployed for less than a year in December 1997. Within their duration analysis framework they allow for unobserved heterogeneity. Of course, any such generalisation of CIA has a price in terms of additional restrictions at another place of the model. Lalive et al. (2000) need a much more restrictive specification of both the selection process into the programmes and of the dependence of the labour market outcomes on time and personal characteristics. Furthermore, the heterogeneity of the effects among the participants and nonparticipants is tightly restricted compared to our approach. Their approach is obviously an important improvement compared to many evaluation studies with duration models performed in the past. However, we believe that given the very good data available for this study such assumptions are an unnecessary high price to pay in order to introduce unobserved heterogeneity. ${ }^{40}$ With respect to results, the most striking difference compared to our results is a positive effect for EMPLOYMENT PROGRAMMES for women after the programme ended that dominates the initial negative effect during the programme (see also Section 5.4). On the other hand, the largest programme, TEMPORARY WAGE SUBSIDY, is treated as a censored exit state and not as a programme at all. ${ }^{41}$

\subsection{Summary of the results}

Perhaps the most important result of our evaluation study is that we find that two different types of temporary employment programmes have very different effects. On the one hand there are

\footnotetext{
${ }^{38}$ See Figures B.10a, B.10b, and B.10c in Appendix B.3.

39 See Figures B.11a, B.11b, and B.11c in Appendix B.3.

40 Again, the assumptions needed for the relation of the unobserved heterogeneity to the other components of the models are very tight.
} 
traditional employment programmes. These programmes usually take place in a sheltered labour market that is not supposed to be in competition with the regular labour market. For these programmes we find significant negative effects. This result corresponds to what has been found in evaluation studies for other countries. Our conjecture is that the additional amount of human capital obtained in these programmes is too small to compensate for the initial negative effects due to reduced job search.

On the other hand we find a very successful temporary employment programme that is rather unique. It is based on a wage subsidy scheme where the unemployed are encouraged to accept jobs that pay less than the unemployment benefit. The difference is overcompensated by payments from the unemployment insurance. Jobs in this programme are within the regular labour market. Here, our conjecture for the reasons for the positive effect is that working in a job in the competitive market is valued by potential future employers because the unemployed still keeps alive work-habit specific human capital. The idea here is that working in a market environment is different from the work environment in an employment programme intended solely for the unemployed. Furthermore, this programme could be used as a cheap screening device by future employers. They could use the programme to uncover otherwise unobserved characteristics and offer regular jobs to 'good' programme participants.

As stated in Section 2 TEMPORARY WAGE SUBSIDY is considered as a potentially powerful instrument by the OECD. Our results indicate that this is true. However, there is concern regarding potential negative incentive effects of TEMPORARY WAGE SUBSIDY in terms of underbidding of the wages set in collective agreements and avoidance of dismissal protection. At this point we do not know whether these considerations are of any importance.

\section{Conclusions}

This paper provides a microeconometric evaluation of the different programmes of the Swiss ALMP, including TEMPORARY WAGE SUBSIDY. We focus on the differences of success in the labour market that are due to these programmes. The estimates are based on a rich data base constructed from administrative records of the unemployment insurance system as well as from social insurance. We use a matching estimator allowing for unrestricted effect heterogeneity among

\footnotetext{
${ }^{41}$ It will be left for future work to resolve these issues and to find out were the differences in the results originated.
} 
the population as well as for heterogeneity with respect to the fairly different programmes the Swiss active labour market policy is made of.

Our results point to considerable heterogeneity both with respect to the effects of the different programmes as well as with respect to the effects in different subpopulations. First, EMPLOYMENT PROGRAMMES perform very poorly. We attribute this to the fact that the resulting reduction of received job offers due to being in these comparatively long programmes by far outweighs the gains in terms of additional work experience provided by these programmes. An exception appears for women in PUBLIC EMPLOYMENT PROGRAMMES. To uncover the reason for this exception will be left to future research.

VOCATIONAL TRAINING PROGRAMMES show a rather mixed performance depending on what specific subprogrammes are considered. Although none of the subprogrammes show a positive effect, FURTHER VOCATIONAL TRAINING, OTHER TRAINING COURSES, as well as COMPUTER COURSES (in particular for foreigners) do not look bad. It will be left for future research to disentangle these still heterogeneous groups of courses further to possibly obtain a more precise picture of their effects. In contrast to these course, LANGUAGE COURSES as well as BASIC COURSES perform rather poorly. However, in particular with respect to LANGUAGE COURSES we suspect that the adjustment for the selection process into these specific courses may still be improved.

TEMPORARY WAGE SUBSIDY appears to be the one clearly successful programme in terms of increasing the chances in the labour market. However, there are some issues whether this programme has incentive effects leading to some undesirable distortions in the labour market (see Section 3).

With respect to general heterogeneity by subpopulation it appears that participating in a programme in the early stages of the unemployment spell is less effective than participating in later stages. We argue that this is due to the fact that participation reduces the number of offers received compared to nonparticipation. This appears to be particularly damaging for people that would be good matches to these offers. With increasing duration of unemployment sorting will have already eliminated the best matches and hence the positive (human capital enhancing) effect of the programme will be more important than the temporary reduction of received job offers.

There are still shortcomings that could be improved in future work. The data base could be extended in several immediate ways: First, it would be desirable to increase the observation period 
to also identify longer term effects of the programmes. Second, having some information from the social security system for the period after 1997 would allow us to take account of the quality of the jobs found in terms of earnings and job stability. Third, having some data about the direct costs of these programmes would be useful to perform some sort of cost benefit analysis.

From a methodological point of view we concentrate on the effect of the first programme in order to avoid obvious endogeneity problems and ignore any further effects of a successive treatments. In fact if there are any such effects, they are attributed to the first treatment. However, before the issues relating to the timing and spacing of various programmes as well as programme careers can be fruitfully evaluated, further methodological advances are necessary that are beyond the scope of this study. The same is true for evaluating the macroeconomic effects of such programmes.

\section{References}

Angrist, J. D. (1998): "Estimating Labor Market Impact of Voluntary Military Service Using Social Security Data ", Econometrica, 66, 249-288.

Angrist, J. D., and A. B. Krueger (1999): "Empirical Strategies in Labor Economics", forthcoming in O. Ashenfelter and D. Card (eds.): Handbook of Labor Economics, Vol. III A, 1277-1366, North-Holland, Amsterdam.

Bauer, T., B. Baumann, and K. Künzi (1999): "Evaluation der Regelung des Zwischenverdienstes in der Schweiz ", seco Publikationen Arbeitsmarktpolitik, 11.99.

Börsch-Supan, A. and Hajivassiliou, V.A. (1993): "Smooth Unbiased Multivariate Probabilities Simulators for Maximum Likelihood Estimation of Limited Dependent Variable Models", Journal of Econometrics, 58, 347368.

Dehejia, R. H. and S. Wahba (1999): "Causal Effects in Non-experimental Studies: Reevaluating the Evaluation of Training Programmes", Journal of the American Statistical Association, 94, 1053-1062.

Fay, Robert G. (1996): "Enhancing the Effectiveness of Active Labour Market Policies: Evidence from Programme Evaluations in OECD countries", Labour Market and Social Policy Occasional Papers, \#18, OECD.

Gerfin, M., and M. Lechner (2000): "An Econometric Evaluation the Swiss Active Labour Market Policies: The Report to the Government", mimeo, in German.

Geweke, J., M. Keane, D. Runkle (1994): "Alternative Computational Approaches to Inference in the Multinomial Probit Model", Review of Economics and Statistics, 1994, 609-632.

Heckman, J. J., and R. Robb (1986): "Alternative Methods for Solving the Problem of Selection Bias in Evaluating the Impact of Treatments on Outcomes", in H. Wainer (ed.), Drawing Inferences from Self-Selected Samples, New York: Springer, 1986, 63-107.

Heckman, J. J., H. Ichimura, and P. Todd (1998): "Matching as an Econometric Evaluation Estimator", Review of Economic Studies, 65, 261-294.

Heckman, J. J., H. Ichimura, J. A. Smith, and P. Todd (1998): "Characterisation Selection Bias Using Experimental Data", Econometrica, 66, 1017-1098.

Heckman, J. J., R. J. LaLonde, and J. A. Smith (1999): "The Economics and Econometrics of Active Labor Market Programs", forthcoming in O. Ashenfelter and D. Card (eds.): Handbook of Labor Economics, Vol. III A, , 18652097, North-Holland, Amsterdam. 
Holland, P. W. (1986): "Statistics and Causal Inference", Journal of the American Statistical Association, 81, 945970 , with discussion.

Imbens, G. W. (1999): "The Role of the Propensity Score in Estimating Dose-Response Functions", NBER Technical Working Paper, 237, 1999.

Lalive, R., J. C. van Ours, and J. Zweimüller (2000): "The Impact of Active Labor Market Policies and Benefit Entitlement Rules on the Duration of Unemployment", mimeo.

LaLonde, R. J. (1986): "Evaluating the Econometric Evaluations of Training Programs with Experimental Data", American Economic Review, 76, 604-620.

Lechner, M. (1999a): "Identification and estimation of causal effects of multiple treatments under the conditional independence assumption", Discussion paper 9908, University of St. Gallen, forthcoming in M. Lechner and F. Pfeiffer (eds., 2000), Econometric Evaluations of Active Labour Market Policies in Europe, Physica..

Lechner, M. (1999b): "Earnings and Employment Effects of Continuous Off-the-Job Training in East Germany After Unification", Journal of Business \& Economic Statistics, 17, 74-90.

Lechner, M. (2000a), "An Evaluation of Public Sector Sponsored Continuous Vocational Training Programs in East Germany", forthcoming in: The Journal of Human Resources.

Lechner, M. (2000b): "Programme Heterogeneity and Propensity Score Matching: An Application to the Evaluation of Active Labour Market Policies“, Discussion paper 200001, University of St. Gallen.

McFadden, D. (1984): "Econometric Analysis of Qualitative Response Models", in Z. Griliches and M. D. Intriligator (eds.), Handbook of Econometrics, Volume 2, 1396-1457.

OECD (1996), Labour Market Policies in Switzerland, Paris.

Rosenbaum, P. R., and D. B. Rubin (1983): "The Central Role of the Propensity Score in Observational Studies for Causal Effects", Biometrica, 70, 41-50.

Rosenbaum, P. R., and D. B. Rubin (1985): "Constructing a Control Group Using Multivariate Matched Sampling Methods That Incorporate the Propensity Score", The American Statistician, 39, 33-38.

Roy, A. D. (1951): "Some Thoughts on the Distribution of Earnings", Oxford Economic Papers, 3, 135-146.

Rubin, D. B. (1974): "Estimating Causal Effects of Treatments in Randomized and Nonrandomized Studies", Journal of Educational Psychology, 66, 688-701.

Rubin, D. B. (1977): "Assignment to Treatment Group on the Basis of a Covariate", Journal of Educational Statistics, 2, 1-26.

Rubin, D. B. (1991): "Practical Implications of Modes of Statistical Inference for Causal Effects and the Critical Role of the Assignment Mechanism", Biometrics, 47, 1213-1234. 


\section{Appendix A: Data}

\section{Appendix A.1: $\quad$ Aggregation of training courses}

When defining the categories used in the estimation we try to combine programmes that are similar. Furthermore, the resulting groups should have a sufficient size in terms of observations. Still there remains some heterogeneity, especially in OTHER COURSES and to lesser extent in FURTHER VOCATIONAL TRAINING. BASIC COURSES also is a rather heterogeneous group.

Table A.1: Aggregation of training courses

\begin{tabular}{|c|c|}
\hline Programme & Code in ASAL data set (variable PROJEKTART) \\
\hline BASIC COURSES & $\begin{array}{l}\text { 2: Basic programme } \\
\text { 3: Courses to promote self-esteem and personality } \\
\text { 4: Courses for acquiring basic skills }\end{array}$ \\
\hline LANGUAGE COURSES & 5: Language course \\
\hline COMPUTER COURSES & $\begin{array}{l}\text { 6: General computer course } \\
\text { 7: Specific computer course }\end{array}$ \\
\hline FURTHER VOCATIONAL TRAINING & $\begin{array}{l}\text { 8: Business and trade training (up to level of vocational degree) } \\
\text { 9: Business and trade training (above level of vocational degree) } \\
\text { 10: Manufacturing and technical training (up to level of vocational degree) } \\
\text { 11: Manufacturing and technical training (above level of vocational degree) }\end{array}$ \\
\hline OTHER COURSES & $\begin{array}{l}\text { 12: Practice firms } \\
\text { 13: Practical courses for young unemployed } \\
\text { 14: Courses for jobs in the tourism sector } \\
\text { 15: Courses for jobs in the health care sector } \\
\text { 16: Other courses }\end{array}$ \\
\hline
\end{tabular}




\section{Appendix A.2: $\quad$ Sample selection and descriptive statistics}

Table A.2: Sample selection rules

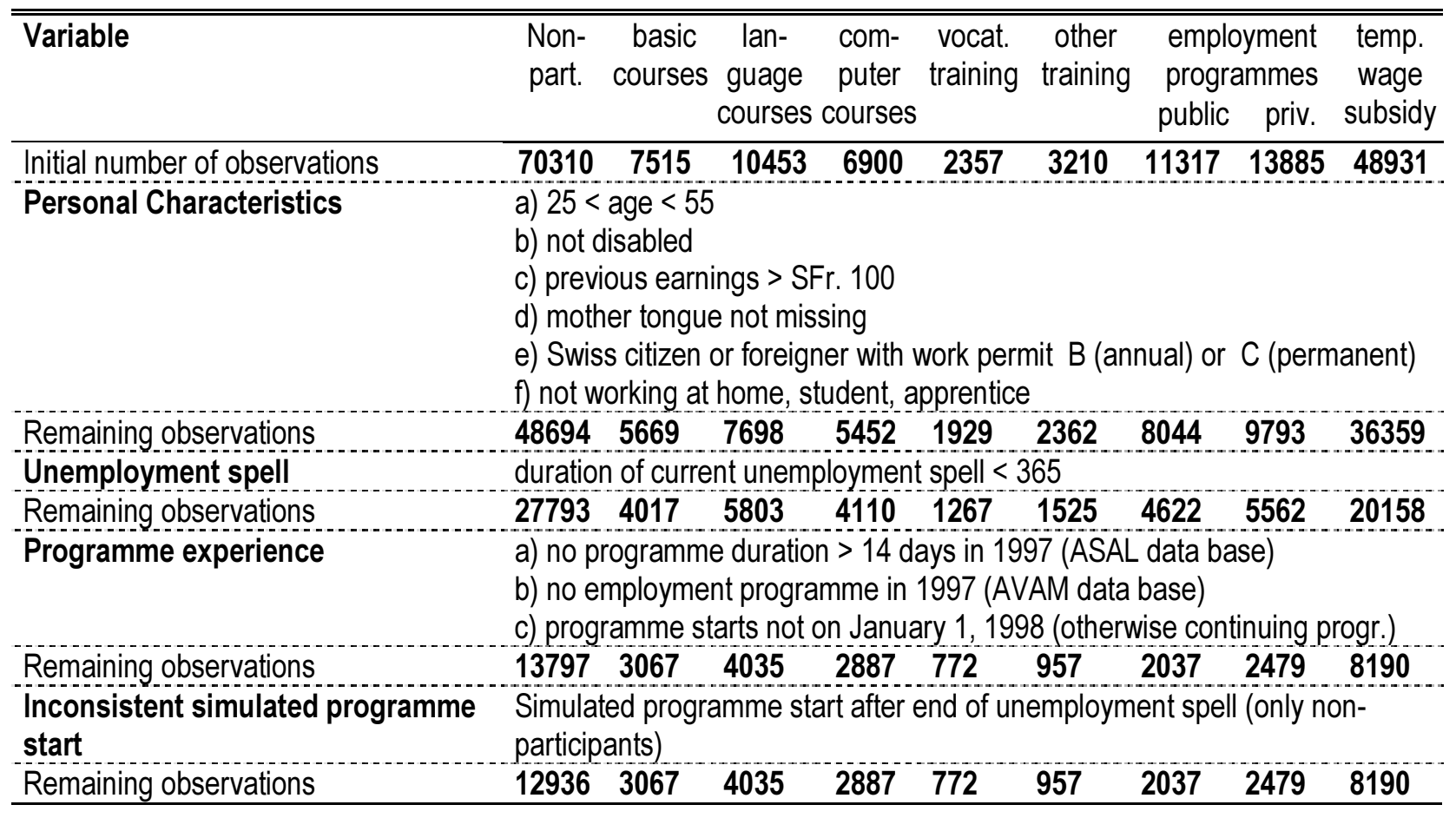

The data selection process is performed in four steps as indicated in Table A.2. The first step relates to personal characteristics. With the age restriction we want to avoid problems with schooling and early retirement options.

We exclude persons who are long-term unemployed on December, 31, 1997 (step two) and who have previously participated in employment programmes (step 3). Finally we exclude all nonparticipants whose simulated programme starting point is later than their exit from unemployment (see section 3 for details).

The resulting data set is then merged with the social security records. After deleting several observations with missing information in the social security data we end up with our estimation data with sample size 19’307. The descriptive statistics of this data set are presented in Table A.3. 
Table A.3: Descriptive Statistics

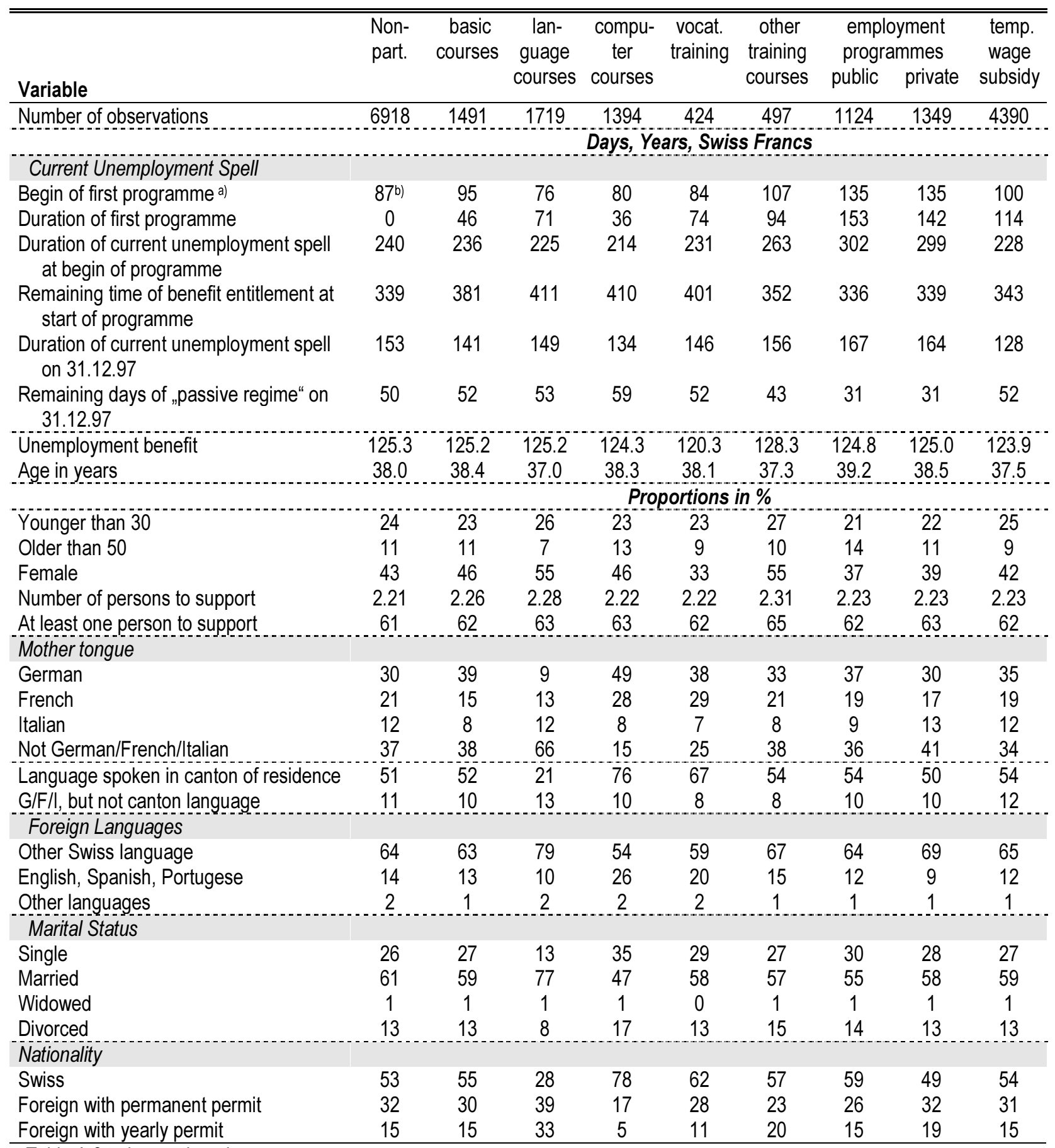

Table A.3 to be continued 
Table A.3 continued

\begin{tabular}{|c|c|c|c|c|c|c|c|c|c|}
\hline Variable & $\begin{array}{l}\text { Non- } \\
\text { part. }\end{array}$ & $\begin{array}{c}\text { basic } \\
\text { courses }\end{array}$ & $\begin{array}{c}\text { lan- } \\
\text { guage } \\
\text { courses }\end{array}$ & $\begin{array}{c}\text { compu- } \\
\text { ter } \\
\text { courses }\end{array}$ & $\begin{array}{l}\text { vocat. } \\
\text { training }\end{array}$ & $\begin{array}{c}\text { other } \\
\text { training } \\
\text { courses }\end{array}$ & \multicolumn{2}{|c|}{$\begin{array}{c}\text { employment } \\
\text { programmes }\end{array}$} & $\begin{array}{l}\text { temp. } \\
\text { wage } \\
\text { subsidy }\end{array}$ \\
\hline \multicolumn{10}{|l|}{ Qualification } \\
\hline Skilled & 53 & 54 & 34 & 80 & 63 & 51 & 54 & 43 & 54 \\
\hline Semi-skilled & 16 & 15 & 17 & 9 & 18 & 18 & 18 & 16 & 17 \\
\hline Unskilled & 31 & 31 & 49 & 11 & 19 & 31 & 28 & 41 & 29 \\
\hline \multicolumn{10}{|l|}{ Chances to find $a j o b$} \\
\hline No Information & 6 & 5 & 5 & 5 & 4 & 4 & 6 & 4 & 8 \\
\hline Very easy & 6 & 4 & 4 & 5 & 5 & 6 & 3 & 5 & 6 \\
\hline Easy & 14 & 13 & 10 & 19 & 14 & 14 & 13 & 12 & 17 \\
\hline Medium & 53 & 57 & 54 & 58 & 62 & 57 & 56 & 52 & 56 \\
\hline Difficult & 17 & 18 & 25 & 11 & 13 & 15 & 18 & 22 & 12 \\
\hline Special case & 4 & 3 & 2 & 1 & 2 & 4 & 4 & 5 & 2 \\
\hline \multicolumn{10}{|l|}{ Mobility } \\
\hline Not mobile & 12 & 4 & 8 & 8 & 6 & 11 & 5 & 5 & 8 \\
\hline Daily commuter & 83 & 91 & 88 & 85 & 88 & 84 & 90 & 89 & 88 \\
\hline Mobile within Switzerland or abroad & 5 & 5 & 4 & 7 & 5 & 5 & 5 & 5 & 5 \\
\hline \multicolumn{10}{|l|}{ Looking for ..... job } \\
\hline Full-time & 34 & 39 & 43 & 34 & 40 & 35 & 37 & 35 & 38 \\
\hline Part-time & 16 & 14 & 12 & 18 & 11 & 16 & 12 & 12 & 12 \\
\hline No information & 49 & 47 & 45 & 49 & 49 & 49 & 51 & 52 & 50 \\
\hline \multicolumn{10}{|l|}{ Unemployment-status } \\
\hline Full-time & 78 & 81 & 83 & 77 & 85 & 81 & 84 & 81 & 81 \\
\hline Part-time & 18 & 16 & 14 & 18 & 11 & 16 & 13 & 15 & 13 \\
\hline In part-time employment & 2 & 1 & 1 & 1 & 1 & 1 & 1 & 2 & 4 \\
\hline Other & 2 & 2 & 2 & 3 & 3 & 1 & 2 & 2 & 3 \\
\hline \multicolumn{10}{|l|}{ Monthly earnings in last job } \\
\hline Less than 1000 & 2 & 2 & 3 & 4 & 3 & 1 & 2 & 2 & 3 \\
\hline Between 1000 and 2000 & 11 & 11 & 13 & 12 & 14 & 10 & 11 & 10 & 11 \\
\hline Between 2000 and 3000 & 25 & 24 & 21 & 22 & 25 & 25 & 24 & 25 & 24 \\
\hline Between 3000 and 4000 & 27 & 27 & 29 & 27 & 27 & 27 & 27 & 28 & 28 \\
\hline Between 4000 and 5000 & 20 & 20 & 17 & 17 & 17 & 17 & 19 & 19 & 20 \\
\hline Between 5000 and 6000 & 8 & 9 & 9 & 9 & 6 & 11 & 9 & 7 & 8 \\
\hline More than 6000 & 8 & 7 & 8 & 9 & 8 & 9 & 7 & 8 & 7 \\
\hline \multicolumn{10}{|c|}{ Duration of unemployment spell at beginning of programme } \\
\hline Less than 90 days & 18 & 19 & 17 & 18 & 15 & 10 & 6 & 7 & 19 \\
\hline Less than 180Tage & 42 & 44 & 44 & 48 & 44 & 34 & 23 & 24 & 44 \\
\hline Less than 270 days & 60 & 62 & 66 & 70 & 65 & 58 & 42 & 44 & 63 \\
\hline Less than 365 days & 78 & 80 & 84 & 85 & 81 & 76 & 65 & 66 & 81 \\
\hline More than 365 days & 22. & 20 & 16 & 15 & 19 & 24 & 35 & 34 & 19 \\
\hline \multicolumn{10}{|l|}{ Job position } \\
\hline Self-employed & 1 & 0 & 1 & 2 & 1 & 0 & 1 & 1 & 0 \\
\hline High (management, etc.) & 6 & 7 & 3 & 9 & 10 & 4 & 4 & 3 & 5 \\
\hline Medium & 56 & 52 & 39 & 73 & 60 & 55 & 52 & 46 & 58 \\
\hline Low & 37 & 41 & 58 & 16 & 28 & 41 & 44 & 51 & 37 \\
\hline
\end{tabular}

Table A.3 to be continued 
Table A.3 continued

\begin{tabular}{|c|c|c|c|c|c|c|c|c|c|}
\hline Variable & $\begin{array}{l}\text { Non- } \\
\text { part. }\end{array}$ & $\begin{array}{c}\text { basic } \\
\text { courses }\end{array}$ & $\begin{array}{c}\text { lan- } \\
\text { guage } \\
\text { courses }\end{array}$ & $\begin{array}{c}\text { compu- } \\
\text { ter } \\
\text { courses }\end{array}$ & $\begin{array}{l}\text { vocat. } \\
\text { training }\end{array}$ & $\begin{array}{c}\text { other } \\
\text { training } \\
\text { courses }\end{array}$ & $\begin{array}{r}\text { emplc } \\
\text { progra } \\
\text { public } \\
\end{array}$ & $\begin{array}{l}\text { yment } \\
\text { immes } \\
\text { private }\end{array}$ & $\begin{array}{c}\text { temp. } \\
\text { wage } \\
\text { subsidy }\end{array}$ \\
\hline \multicolumn{10}{|l|}{ Previous occupation } \\
\hline Agriculture & 2 & 1 & 2 & 1 & 0 & 1 & 2 & 2 & 2 \\
\hline Mining & 0 & 0 & 0 & 0 & 0 & 0 & 0 & 0 & 0 \\
\hline Food, tobacco & 1 & 1 & 1 & 1 & 0 & 1 & 1 & 1 & 1 \\
\hline Textiles & 1 & 1 & 4 & 1 & 0 & 0 & 1 & 2 & 1 \\
\hline Wood and paper & 1 & 1 & 1 & 1 & 1 & 0 & 2 & 2 & 1 \\
\hline Chemical & 0 & 0 & 0 & 0 & 0 & 0 & 0 & 0 & 0 \\
\hline Metals & 7 & 8 & 5 & 6 & 12 & 4 & 6 & 9 & 8 \\
\hline Watches, jewelry & 0 & 0 & 0 & 0 & 0 & 0 & 0 & 1 & 0 \\
\hline Health care & 3 & 3 & 2 & 3 & 2 & 5 & 3 & 2 & 3 \\
\hline Architecture, engineers & 1 & 2 & 2 & 5 & 5 & 1 & 2 & 1 & 2 \\
\hline Construction & 8 & 6 & 7 & 3 & 7 & 4 & 9 & 8 & 10 \\
\hline Transportation & 4 & 3 & 1 & 2 & 2 & 3 & 4 & 5 & 4 \\
\hline Restaurants & 16 & 14 & 19 & 8 & 7 & 32 & 14 & 15 & 17 \\
\hline Printing & 1 & 1 & 0 & 1 & 1 & 1 & 1 & 1 & 1 \\
\hline Minerals & 0 & 0 & 0 & 0 & 0 & 1 & 0 & 0 & 0 \\
\hline Entrepreneurs, senior officials, justice & 4 & 4 & 3 & 5 & 5 & 3 & 2 & 2 & 2 \\
\hline Painting, technical drawing & 5 & 5 & 5 & 6 & 8 & 2 & 7 & 5 & 8 \\
\hline Office and computer & 14 & 15 & 13 & 28 & 19 & 17 & 14 & 11 & 12 \\
\hline Retail trade & 9 & 11 & 5 & 13 & 15 & 7 & 7 & 6 & 7 \\
\hline Security, cleaning, clerical, social work & 5 & 5 & 9 & 2 & 2 & 5 & 5 & 5 & 5 \\
\hline Science & 2 & 1 & 1 & 3 & 2 & 1 & 2 & 1 & 1 \\
\hline Artist & 2 & 1 & 1 & 2 & 1 & 1 & 1 & 2 & 2 \\
\hline Education & 2 & 1 & 1 & 2 & 1 & 2 & 3 & 2 & 3 \\
\hline News and communication & 1 & 1 & 1 & 2 & 1 & 0 & 1 & 1 & 1 \\
\hline Body care & 1 & 1 & 0 & 0 & 0 & 1 & 0 & 0 & 1 \\
\hline Other & 8 & 12 & 13 & 5 & 7 & 6 & 11 & 16 & 8 \\
\hline \multicolumn{10}{|c|}{ Correspondence between desired and previous job } \\
\hline 2-digit & 73 & 72 & 70 & 74 & 69 & 67 & 68 & 69 & 75 \\
\hline 3-digit & 68 & 66 & 65 & 66 & 62 & 60 & 62 & 63 & 69 \\
\hline \multicolumn{10}{|l|}{ Previous industry sector } \\
\hline Agriculture & 2 & 1 & 1 & 1 & 0 & 1 & 2 & 2 & 2 \\
\hline Mining, energy, water & 0 & 0 & 0 & 0 & 0 & 0 & 0 & 0 & 0 \\
\hline Construction & 13 & 10 & 11 & 7 & 14 & 6 & 14 & 11 & 17 \\
\hline Public services & 11 & 9 & 9 & 9 & 8 & 10 & 10 & 10 & 6 \\
\hline Other services & 5 & 4 & 4 & 6 & 4 & 6 & 6 & 7 & 5 \\
\hline Health care & 4 & 3 & 3 & 4 & 3 & 5 & 4 & 3 & 4 \\
\hline Research and development & 0 & 0 & 0 & 1 & 0 & 1 & 1 & 0 & 0 \\
\hline Education & 2 & 2 & 1 & 2 & 2 & 2 & 3 & 2 & 2 \\
\hline Banking, insurance & 3 & 3 & 2 & 6 & 5 & 4 & 2 & 1 & 2 \\
\hline Real estate & 1 & 1 & 1 & 1 & 1 & 1 & 1 & 1 & 1 \\
\hline Consulting & 11 & 11 & 11 & 16 & 12 & 7 & 10 & 11 & 12 \\
\hline Transportation & 3 & 3 & 2 & 4 & 4 & 3 & 3 & 3 & 3 \\
\hline News and communication & 0 & 0 & 0 & 1 & 0 & 1 & 0 & 1 & 0 \\
\hline Trade & 15 & 17 & 15 & 19 & 17 & 13 & 15 & 15 & 13 \\
\hline
\end{tabular}

Table A.3 to be continued 
Table A.3 continued

\begin{tabular}{|c|c|c|c|c|c|c|c|c|c|}
\hline \multirow[b]{2}{*}{ Variable } & \multirow[t]{2}{*}{$\begin{array}{l}\text { Non- } \\
\text { part. }\end{array}$} & \multirow[t]{2}{*}{$\begin{array}{c}\text { basic } \\
\text { courses }\end{array}$} & \multirow{2}{*}{$\begin{array}{c}\text { lan- } \\
\text { guage } \\
\text { courses }\end{array}$} & \multirow{2}{*}{$\begin{array}{c}\text { compu- } \\
\text { ter } \\
\text { courses }\end{array}$} & \multirow[t]{2}{*}{$\begin{array}{l}\text { vocat. } \\
\text { training }\end{array}$} & \multirow{2}{*}{$\begin{array}{c}\text { other } \\
\text { training } \\
\text { courses }\end{array}$} & \multicolumn{2}{|c|}{$\begin{array}{c}\text { employment } \\
\text { programmes }\end{array}$} & \multirow{2}{*}{$\begin{array}{c}\text { temp. } \\
\text { wage } \\
\text { subsidy }\end{array}$} \\
\hline & & & & & & & public & private & \\
\hline Restaurants, catering & 15 & 13 & 17 & 8 & 6 & 27 & 11 & 13 & 16 \\
\hline Repairs & 2 & 1 & 1 & 2 & 1 & 1 & 1 & 1 & 2 \\
\hline Food, tobacco & 1 & 2 & 2 & 1 & 0 & 1 & 1 & 2 & 1 \\
\hline Textiles & 1 & 2 & 2 & 1 & 1 & 1 & 1 & 2 & 1 \\
\hline Wood, furniture & 1 & 1 & 1 & 1 & 2 & 1 & 1 & 1 & 1 \\
\hline Paper, paper products & 0 & 0 & 0 & 0 & 0 & 0 & 0 & 0 & 0 \\
\hline Printing & 1 & 2 & 1 & 3 & 1 & 2 & 1 & 1 & 1 \\
\hline Leather & 0 & 0 & 0 & 0 & 0 & 0 & 0 & 0 & 0 \\
\hline Chemical & 1 & 2 & 1 & 1 & 1 & 1 & 1 & 1 & 1 \\
\hline Non-ferrous minerals & 1 & 1 & 1 & 0 & 1 & 1 & 1 & 1 & 1 \\
\hline Metals & 2 & 3 & 3 & 2 & 6 & 2 & 3 & 4 & 2 \\
\hline Machinery and equipment & 2 & 3 & 3 & 2 & 6 & 2 & 3 & 2 & 3 \\
\hline Electrical machinery, optics & 2 & 2 & 3 & 2 & 3 & 1 & 2 & 3 & 2 \\
\hline Watches, jewelry & 1 & 1 & 0 & 1 & 1 & 1 & 1 & 1 & 1 \\
\hline Other manufacturing & 1 & 1 & 1 & 1 & 1 & 0 & 1 & 1 & 1 \\
\hline Industry unemployment rate in $\%, 1 / 98$ & 6.6 & 6.3 & 6.8 & 5.7 & 5.6 & 7.5 & 6.2 & 6.4 & 6.7 \\
\hline \multicolumn{10}{|l|}{ Canton } \\
\hline Zurich & 22 & 22 & 27 & 21 & 23 & 18 & 29 & 6 & 18 \\
\hline Berne & 8 & 10 & 8 & 9 & 5 & 5 & 14 & 14 & 10 \\
\hline Lucerne & 3 & 4 & 5 & 5 & 4 & 8 & 3 & 4 & 3 \\
\hline Uri & 0 & 0 & 0 & 0 & 0 & 2 & 0 & 0 & 0 \\
\hline Schwyz & 0 & 3 & 1 & 1 & 0 & 1 & 2 & 1 & 1 \\
\hline Obwalden & 0 & 0 & 0 & 0 & 0 & 2 & 0 & 0 & 0 \\
\hline Nidwalden & 0 & 0 & 0 & 0 & 0 & 1 & 1 & 0 & 0 \\
\hline Glarus & 0 & 0 & 0 & 0 & 0 & 3 & 1 & 0 & 0 \\
\hline Zug & 1 & 0 & 2 & 1 & 1 & 1 & 1 & 2 & 1 \\
\hline Freiburg & 2 & 6 & 4 & 4 & 2 & 2 & 6 & 2 & 3 \\
\hline Solothurn & 2 & 5 & 2 & 2 & 3 & 1 & 1 & 8 & 4 \\
\hline Basel-City & 4 & 4 & 3 & 4 & 2 & 2 & 2 & 4 & 3 \\
\hline Basel-Landschaft & 2 & 4 & 2 & 3 & 2 & 1 & 1 & 3 & 2 \\
\hline Schaffhausen & 1 & 0 & 1 & 2 & 2 & 0 & 1 & 0 & 1 \\
\hline Appenzell AR & 0 & 0 & 0 & 0 & 0 & 0 & 0 & 1 & 0 \\
\hline Appenzell IR & 0 & 0 & 0 & 0 & 0 & 0 & 0 & 0 & 0 \\
\hline St. Gall & 4 & 6 & 9 & 4 & 5 & 5 & 2 & 2 & 5 \\
\hline Graubünden & 2 & 3 & 1 & 2 & 1 & 1 & 0 & 3 & 1 \\
\hline Aargau & 5 & 5 & 9 & 4 & 7 & 6 & 1 & 8 & 5 \\
\hline Thurgau & 1 & 1 & 3 & 3 & 1 & 2 & 3 & 1 & 2 \\
\hline Ticino & 9 & 2 & 5 & 5 & 4 & 10 & 4 & 12 & 8 \\
\hline Waadt & 14 & 15 & 6 & 17 & 19 & 14 & 10 & 13 & 13 \\
\hline Wallis & 4 & 3 & 3 & 3 & 5 & 4 & 7 & 7 & 8 \\
\hline Neuenburg & 4 & 1 & 1 & 2 & 1 & 2 & 7 & 4 & 3 \\
\hline Geneva & 12 & 3 & 8 & 9 & 7 & 10 & 3 & 4 & 7 \\
\hline Jura & 1 & 1 & 0 & 1 & 7 & 1 & 2 & 1 & 1 \\
\hline Cantonal unemployment rate & 5.33 & 4.72 & 4.65 & 5.09 & 5.19 & 5.09 & 5.02 & 5.16 & 5.21 \\
\hline
\end{tabular}


Table A.3 continued

\begin{tabular}{|c|c|c|c|c|c|c|c|c|c|}
\hline Variable & $\begin{array}{l}\text { Non- } \\
\text { part. }\end{array}$ & $\begin{array}{c}\text { basic } \\
\text { courses }\end{array}$ & $\begin{array}{c}\text { lan- } \\
\text { guage } \\
\text { courses }\end{array}$ & \multirow[t]{2}{*}{$\begin{array}{l}\text { compu- } \\
\text { ter } \\
\text { courses }\end{array}$} & $\begin{array}{l}\text { vocat. } \\
\text { training }\end{array}$ & $\begin{array}{c}\text { other } \\
\text { training } \\
\text { courses }\end{array}$ & \multicolumn{2}{|c|}{$\begin{array}{c}\text { employment } \\
\text { programmes }\end{array}$} & $\begin{array}{l}\text { temp. } \\
\text { wage } \\
\text { subsidy }\end{array}$ \\
\hline \multicolumn{9}{|l|}{ Canton language } & \\
\hline German & 53 & 70 & 74 & 59 & 56 & 58 & 61 & 58 & 58 \\
\hline French & 38 & 28 & 21 & 36 & 41 & 32 & 35 & 31 & 34 \\
\hline Italian & 9 & 2 & 5 & 5 & 4 & 10 & 4 & 12 & 8 \\
\hline \multicolumn{10}{|l|}{ Region } \\
\hline Eastern & 8 & 12 & 15 & 10 & 9 & 11 & 7 & 7 & 10 \\
\hline Central & 4 & 7 & 8 & 7 & 6 & 14 & 7 & 7 & 5 \\
\hline South-west & 31 & 20 & 16 & 29 & 31 & 28 & 21 & 24 & 28 \\
\hline North-west & 10 & 14 & 14 & 10 & 11 & 8 & 4 & 15 & 11 \\
\hline West & 17 & 23 & 16 & 18 & 17 & 10 & 29 & 29 & 20 \\
\hline \multicolumn{10}{|l|}{ Size of town where worked before } \\
\hline$<1000$ & 8 & 7 & 5 & 9 & 8 & 7 & 8 & 9 & 9 \\
\hline$<2000$ & 16 & 14 & 11 & 16 & 16 & 15 & 16 & 19 & 18 \\
\hline$<5000$ & 32 & 31 & 28 & 31 & 34 & 35 & 33 & 37 & 36 \\
\hline$<10^{\prime} 000$ & 44 & 45 & 42 & 45 & 47 & 47 & 46 & 51 & 49 \\
\hline$<20^{\prime} 000$ & 62 & 62 & 60 & 62 & 65 & 62 & 61 & 68 & 67 \\
\hline$<30^{\prime} 000$ & 67 & 66 & 67 & 68 & 72 & 69 & 66 & 76 & 73 \\
\hline$<50^{\prime} 000$ & 72 & 70 & 71 & 73 & 74 & 72 & 73 & 80 & 77 \\
\hline$<100^{\prime} 000$ & 76 & 76 & 79 & 78 & 80 & 76 & 77 & 84 & 81 \\
\hline$>100^{\prime} 000$. & 24 & 24 & 21 & 22 & 20 & 24 & 23 & 16 & 19 \\
\hline$<200^{\prime} 000$. & 92 & 89 & 89 & 93 & 92 & 90 & 88 & 97 & 94 \\
\hline$>200^{\prime} 000$ & 8 & 11 & 11 & 7 & 8 & 10 & 12 & 3 & 6 \\
\hline \multicolumn{10}{|l|}{ Region of placement office } \\
\hline Large city & 47 & 42 & 42 & 45 & 42 & 36 & 44 & 26 & 38 \\
\hline Small city & 37 & 36 & 40 & 40 & 42 & 45 & 38 & 52 & 42 \\
\hline Rural & 15 & 21 & 17 & 14 & 17 & 18 & 17 & 20 & 19 \\
\hline No information & 1 & 1 & 1 & 1 & 0 & 0 & 0 & 1 & 1 \\
\hline \multicolumn{10}{|c|}{ Long-term unemployment in regional placement office } \\
\hline Inflow to long-term unemployment c) & 2.1 & 2.0 & 2.0 & 2.1 & 2.2 & 2.1 & 2.0 & 2.0 & 1.9 \\
\hline Outflow from long-term unemployment $\mathrm{d}$ ) & 1.1 & 1.1 & 1.1 & 1.2 & 1.2 & 1.2 & 1.0 & 1.1 & 1.1 \\
\hline No information & 17 & 21 & 18 & 18 & 14 & 16 & 21 & 18 & 21 \\
\hline \multicolumn{10}{|l|}{ Remaining benefit eligibility } \\
\hline Less than 6 months & 21 & 16 & 12 & 14 & 13 & 19 & 16 & 17 & 20 \\
\hline Less than 12 months & 47 & 38 & 32 & 32 & 36 & 46 & 49 & 50 & 45 \\
\hline Less than 18 months & 77 & 69 & 66 & 62 & 71 & 79 & 83 & 82 & 72 \\
\hline More than 18 months & 17 & 23 & 25 & 28 & 25 & 18 & 12 & 14 & 19 \\
\hline \multicolumn{10}{|l|}{ Unemployment history } \\
\hline First spell & 60 & 64 & 70 & 67 & 63 & 57 & 64 & 63 & 57 \\
\hline Number of spells prior to current spell & 0.51 & 0.45 & 0.37 & 0.39 & 0.47 & 0.55 & 0.46 & 0.46 & 0.55 \\
\hline Duration of previous spell / 1000 & 0.08 & 0.07 & 0.06 & 0.07 & 0.07 & 0.08 & 0.09 & 0.09 & 0.08 \\
\hline
\end{tabular}




\begin{tabular}{|c|c|c|c|c|c|c|c|c|c|}
\hline Variable & $\begin{array}{l}\text { Non- } \\
\text { part. }\end{array}$ & $\begin{array}{c}\text { basic } \\
\text { courses }\end{array}$ & \multirow[t]{2}{*}{$\begin{array}{c}\text { lan- } \\
\text { guage } \\
\text { courses }\end{array}$} & \multirow[t]{2}{*}{$\begin{array}{l}\text { compu- } \\
\text { ter } \\
\text { courses }\end{array}$} & $\begin{array}{l}\text { vocat. } \\
\text { training }\end{array}$ & \multirow[t]{2}{*}{$\begin{array}{l}\text { other } \\
\text { training } \\
\text { courses }\end{array}$} & \multicolumn{2}{|c|}{$\begin{array}{c}\text { employment } \\
\text { programmes }\end{array}$} & $\begin{array}{l}\text { temp. } \\
\text { wage } \\
\text { subsidy }\end{array}$ \\
\hline Sanction days without benefit payment & & & & & & & & & \\
\hline $\begin{array}{l}\text { Number of sanction days during last } \\
\text { unemployment spell }\end{array}$ & 4.4 & 5.0 & 4.0 & 3.6 & 4.7 & 5.2 & 4.2 & 5.2 & 3.7 \\
\hline Share in total unemployment spell & 0.05 & 0.06 & 0.05 & 0.05 & 0.05 & 0.06 & 0.04 & 0.07 & 0.05 \\
\hline Positive number of sanction days (in \%) & 26 & 25 & 25 & 22 & 25 & 28 & 23 & 26 & 22 \\
\hline \multicolumn{10}{|l|}{ Previous programme participation } \\
\hline $\begin{array}{l}\text { Sum of short programs between July and } \\
\text { December } 1997\end{array}$ & 0.04 & 0.08 & 0.07 & 0.09 & 0.10 & 0.08 & 0.05 & 0.07 & 0.06 \\
\hline $\begin{array}{l}\text { Participation in training course or employ- } \\
\text { ment programme between July and } \\
\text { December } 97 \text { (less than } 14 \text { days) }\end{array}$ & 1 & 0 & 1 & 0 & 1 & 1 & 1 & 0 & 0 \\
\hline Employment programme before July 97 & 1 & 1 & 1 & 1 & 1 & 1 & 2 & 1 & 1 \\
\hline Training course before July 97 & 1 & 0 & 1 & 0 & 1 & 1 & 1 & 0 & 0 \\
\hline Temporary wage subsidy before July 97 & 1 & 2 & 1 & 1 & 2 & 1 & 2 & 1 & 3 \\
\hline \multicolumn{10}{|c|}{ Employment history from social security data } \\
\hline $\begin{array}{l}\text { Number of months unemployed since } \\
\text { entry into social security system }\end{array}$ & 7.6 & 6.8 & 5.4 & 6.4 & 6.5 & 6.8 & 7.9 & 8.5 & 6.4 \\
\hline $\begin{array}{l}\text { Number of months employed since entry } \\
\text { into social security system }\end{array}$ & 85 & 86 & 73 & 91 & 90 & 80 & 86 & 82 & 90 \\
\hline $\begin{array}{l}\text { Number of months out of labour force } \\
\text { since entry into social security syst. }\end{array}$ & 15.4 & 14.8 & 14.5 & 14.0 & 13.0 & 15.8 & 14.8 & 15.8 & 12.6 \\
\hline Never unemployed & 36 & 41 & 49 & 43 & 38 & 39 & 38 & 36 & 40 \\
\hline Month of entry into social security system & 12.1 & 12.6 & 27.3 & 8.7 & 10.6 & 17.4 & 11.6 & 13.5 & 11.4 \\
\hline Number of employment spells & 3.53 & 3.28 & 2.87 & 3.03 & 3.18 & 3.23 & 3.44 & 3.61 & 3.51 \\
\hline Number of unemployment spells & 1.41 & 1.26 & 0.92 & 1.11 & 1.24 & 1.27 & 1.4 & 1.51 & 1.29 \\
\hline $\begin{array}{l}\text { Mean duration of employment spell in } \\
\text { months }\end{array}$ & 40 & 43 & 39 & 49 & 46 & 39 & 41 & 37 & 43 \\
\hline $\begin{array}{l}\text { Mean duration of unemployment spell e) in } \\
\text { months }\end{array}$ & 5.9 & 5.9 & 6.5 & 6.3 & 5.8 & 5.7 & 6.2 & 6.2 & 5.3 \\
\hline Standard deviation of wages / 1000 & 0.99 & 0.93 & 0.78 & 1.06 & 1.04 & 0.88 & 0.94 & 0.87 & 0.94 \\
\hline Duration of last employment spell & 40 & 43 & 41 & 48 & 46 & 40 & 42 & 38 & 43 \\
\hline Wage growth during last employment spell & 81 & 180 & 106 & 113 & 25 & 148 & 78 & 62 & 69 \\
\hline Proportion of time unemployed in \% & 7 & 6 & 6 & 6 & 6 & 7 & 7 & 8 & 6 \\
\hline Proportion of time employed in \% & 78 & 79 & 76 & 81 & 81 & 76 & 78 & 76 & 82 \\
\hline
\end{tabular}

Notes: a) The begin of a programme is measured in days since 1.1.98. b) Simulated.

c) Mean number of transition into long-term unemployment relative to total unemployment within regional placement offices. d) Mean number of transitions to employment relative to total unemployment within regional placement offices e) This variable takes a value of zero, if person has never been unemployed before. 


\section{Appendix A.3 Estimates of the multinomial probit model}

Table A.4 shows the estimation results of a multinomial probit model (MNP) using simulated maximum likelihood with the GHK simulator. ${ }^{42}$ Although being fully parametric, the MNP is a flexible version of a discrete choice model, because it does not require the Independence of Irrelevant Alternatives assumption to hold.

The variables that are used in the MNP are selected by a preliminary specification search based on binary probits (each relative to the reference category NONPARTICIPATION) and score tests against omitted variables. Entries for variables excluded from a particular choice equation show a 0 for the coefficient and '-' for the standard error. Based on that the final specification contains a varying number of mainly discrete variables that cover groups of attributes related to personal characteristics, valuations of individual skill and chances on the labour market as assessed by the placement office, previous and desired future occupations, and information related to the current and previous unemployment spell, and past employment and earnings.

In practice, some restrictions on the covariance matrix of the errors terms of the MNP need to be imposed, because not all elements of the covariance matrix are identified and to avoid excessive numerical instability. Guided by considerations of similarity of options and sample size, we allowed for free correlations between COMPUTER COURSES, FURTHER VOCATIONAL TRAINING, LANGUAGE COURSES and BASIC TRAINING, as well as between EMPLOYMENT PROGRAMME (PUBLIC), EMPLOYMENT PROGRAMME (PRIVATE), and TEMPORARY WAGE SUBSIDY. Furthermore, the variance of the error term related to TEMP is not restricted (for details see Table A.5).

42 See for example Börsch-Supan, Hajivassiliou (1993) and Geweke, Keane and Runkle (1994). 
Table A.4: Estimated coefficients of a multinomial probit model for participation in a programme

\begin{tabular}{|c|c|c|c|c|c|c|c|c|}
\hline \multirow[b]{2}{*}{ Variable } & \multirow[t]{2}{*}{$\begin{array}{l}\text { Basic } \\
\text { courses }\end{array}$} & \multirow[t]{2}{*}{$\begin{array}{l}\text { language } \\
\text { courses }\end{array}$} & \multirow[t]{2}{*}{$\begin{array}{c}\text { computer } \\
\text { courses }\end{array}$} & \multirow[t]{2}{*}{$\begin{array}{l}\text { vocat. } \\
\text { training }\end{array}$} & \multirow[t]{2}{*}{$\begin{array}{l}\text { other } \\
\text { training }\end{array}$} & \multicolumn{2}{|c|}{$\begin{array}{l}\text { employment } \\
\text { programme }\end{array}$} & \multirow{2}{*}{$\begin{array}{l}\text { temporary } \\
\text { wage } \\
\text { subsidy }\end{array}$} \\
\hline & & & & & & public & private & \\
\hline Age in years / 10 & 0.06 & 0 & 0 & 0 & 0 & 0.11 & 0.12 & 0 \\
\hline Older than 45 & 0 & -0.11 & 0 & 0 & 0 & 0 & 0 & 0 \\
\hline Female & 0.10 & 0.20 & -0.11 & -0.55 & 0.09 & -0.16 & -0.20 & 0.15 \\
\hline Marital status married & 0 & 0 & -0.19 & 0 & 0 & -0.19 & -0.23 & 0 \\
\hline Marital status divorced & 0 & 0 & 0 & 0 & 0 & 0 & 0 & 0.12 \\
\hline Number of persons to support & 0 & 0.03 & 0 & 0 & 0 & 0 & 0 & 0 \\
\hline \multicolumn{9}{|l|}{ Mother tongue } \\
\hline French & 0 & 1.13 & 0 & 0 & 0 & 0 & 0 & 0 \\
\hline Italian & 0 & 0.74 & 0 & 0 & 0 & 0 & 0 & 0 \\
\hline Not German/French/Italian & 0 & 1.18 & -0.47 & -0.57 & 0 & 0 & 0 & -0.31 \\
\hline GF/l, but not canton language & 0 & 0.39 & 0 & -0.65 & 0 & 0 & -0.13 & -0.11 \\
\hline \multicolumn{9}{|l|}{ Foreign Languages } \\
\hline Other Swiss language & 0 & 0.15 & 0.24 & 0 & 0 & 0.08 & 0.12 & 0.14 \\
\hline English, Spanish, Portuguese & 0 & 0.27 & 0.42 & 0 & 0 & 0 & 0 & 0 \\
\hline \multicolumn{9}{|c|}{ Looking for ... job (reference category: no information) } \\
\hline Full-time & 0 & 0.09 & 0 & 0 & 0 & 0 & 0 & 0 \\
\hline Part-time & 0 & -0.13 & 0 & 0 & 0 & 0 & 0 & -0.21 \\
\hline \multicolumn{9}{|c|}{ Unemployment-status (reference category: part-time) } \\
\hline Full-time & 0.31 & 0.24 & 0.09 & 0.49 & 0.32 & 0.44 & 0.29 & 0.22 \\
\hline In part-time employment & 0 & 0 & 0 & 0 & 0 & 0 & 0 & 1.26 \\
\hline \multicolumn{9}{|l|}{ Nationality (reference category: Swiss) } \\
\hline Foreign with permanent permit & 0 & 0 & -0.50 & 0 & -0.20 & -0.22 & 0 & 0 \\
\hline Foreign with yearly permit & 0 & 0 & -0.74 & 0 & -0.12 & -0.13 & 0.07 & 0 \\
\hline \multicolumn{9}{|c|}{ Monthly earnings in last job (reference category: between 2000 and 6000 ) } \\
\hline Less than 2000 & 0 & 0 & 0.24 & 0.39 & 0 & 0 & 0 & 0 \\
\hline More than 6000 & -0.15 & 0 & 0 & 0 & 0 & 0 & 0 & 0 \\
\hline \multicolumn{9}{|c|}{ Chances to find a job (reference category: medium) } \\
\hline No information & -0.13 & -0.09 & -0.16 & -0.35 & -0.19 & -0.25 & -0.33 & 0.13 \\
\hline Very easy & 0.07 & -0.17 & -0.01 & -0.01 & -0.03 & -0.16 & -0.27 & -0.06 \\
\hline Easy & -0.03 & -0.17 & 0.11 & -0.28 & -0.03 & -0.16 & -0.14 & 0.11 \\
\hline Difficult & -0.05 & 0.12 & -0.25 & -0.36 & -0.16 & -0.09 & 0.02 & -0.34 \\
\hline Special case & -0.14 & -0.24 & -0.79 & -0.93 & -0.08 & -0.20 & -0.04 & -0.87 \\
\hline \multicolumn{9}{|c|}{ Qualification (reference categories: semi-skilled, unskilled) } \\
\hline Skilled & 0 & -0.15 & 0.62 & 0 & 0 & 0 & 0 & 0 \\
\hline \multicolumn{9}{|c|}{$\begin{array}{l}\text { Previous industry sector (reference categories: agriculture, mining/energy/water, other services, health care, education, bank- } \\
\text { ing/insurance, real estate, transportation, news and communication, trade, repairs, food/tobacco, textiles, wood/furniture, } \\
\text { paper/paper products, leather, chemical, non-ferrous minerals, machinery and equipment, electrical machinery/optics, } \\
\text { watches/jewelry, other manufacturing) }\end{array}$} \\
\hline Construction & -0.16 & 0 & 0 & 0 & -0.31 & 0 & -0.36 & 0 \\
\hline Public services & 0 & 0 & 0 & 0 & 0 & 0 & 0 & -0.33 \\
\hline Consulting & 0 & 0 & 0.32 & 0 & -0.17 & 0 & 0 & 0 \\
\hline Restaurants, catering & 0 & 0 & 0 & 0 & 0 & 0 & -0.37 & 0 \\
\hline Printing & 0 & 0 & 0.73 & 0 & 0 & 0 & 0 & 0 \\
\hline Metals & 0 & 0 & 0 & 0.86 & 0 & 0 & 0 & 0 \\
\hline Industry unemployment rate in $\%, 1 / 98$ & -0.08 & -0.06 & -0.32 & -0.68 & 0.03 & -0.18 & 0.15 & 0.05 \\
\hline
\end{tabular}




\begin{tabular}{|c|c|c|c|c|c|c|c|c|}
\hline \multirow[b]{2}{*}{ Variable } & \multirow[t]{2}{*}{$\begin{array}{c}\text { Basic } \\
\text { courses }\end{array}$} & \multirow[t]{2}{*}{$\begin{array}{l}\text { language } \\
\text { courses }\end{array}$} & \multirow[t]{2}{*}{$\begin{array}{c}\text { computer } \\
\text { courses }\end{array}$} & \multirow[t]{2}{*}{$\begin{array}{l}\text { vocat. } \\
\text { training }\end{array}$} & \multirow[t]{2}{*}{$\begin{array}{l}\text { other } \\
\text { training }\end{array}$} & \multicolumn{2}{|c|}{$\begin{array}{l}\text { employment } \\
\text { programme }\end{array}$} & \multirow{2}{*}{$\begin{array}{l}\text { temporary } \\
\text { wage } \\
\text { subsidy }\end{array}$} \\
\hline & & & & & & public & private & \\
\hline \multicolumn{9}{|c|}{ Job position function (reference category: assistant) } \\
\hline Self-employed & 0 & 0 & 0 & 0 & 0 & 0 & 0 & -0.61 \\
\hline High (management, etc.) & 0 & 0 & 0.28 & 0 & -0.24 & -0.41 & -0.45 & 0 \\
\hline Medium & 0 & 0 & 0.40 & 0 & 0 & 0 & -0.13 & 0 \\
\hline \multicolumn{9}{|c|}{ Previous occupation (reference categories: mining, wood and paper, chemical, minerals, artist) } \\
\hline Agriculture & 0 & -0.18 & -0.79 & -2.19 & 0 & 0 & 0 & 0 \\
\hline Food, Tobacco & 0 & -0.46 & 0 & 0 & 0 & 0 & 0 & 0 \\
\hline Textiles & 0 & 0.40 & 0 & 0 & 0 & 0 & 0 & 0 \\
\hline Metals & 0 & -0.31 & -0.20 & 0.72 & 0 & -0.29 & 0 & 0 \\
\hline Health care & 0 & 0 & 0 & 0 & 0.45 & 0 & 0 & 0 \\
\hline Architecture, engineer & 0 & 0.32 & 0.84 & 1.74 & 0 & 0 & 0 & 0 \\
\hline Construction & -0.09 & -0.24 & -0.72 & 0 & 0.00 & 0 & -0.03 & 0 \\
\hline Transportation & 0 & -0.59 & -0.36 & -0.79 & 0 & 0 & 0 & 0 \\
\hline Restaurants & 0 & -0.12 & 0 & 0 & 0.42 & 0 & 0 & 0 \\
\hline Printing & 0 & -0.84 & 0 & 0 & 0 & 0 & 0 & -0.57 \\
\hline Entrepreneurs, senior officials, justice & 0 & 0 & 0 & 0 & 0 & -0.36 & -0.38 & -0.76 \\
\hline Painting, technical drawing & 0 & 0 & 0 & 0.75 & 0 & 0 & 0 & 0.20 \\
\hline Office and computer & 0 & 0.22 & 0.50 & 0.82 & 0.31 & 0 & 0 & -0.25 \\
\hline Retail trade & 0.15 & 0 & 0.36 & 1.10 & 0 & -0.19 & -0.17 & -0.33 \\
\hline Security, cleaning, clerical, social work & 0 & 0 & -0.63 & 0 & 0 & 0 & 0 & 0 \\
\hline Science & -0.40 & 0 & 0 & 0 & 0 & 0 & 0 & -0.49 \\
\hline Education & 0 & 0 & -0.84 & 0 & 0 & 0 & 0 & 0 \\
\hline News and communication & 0 & 0 & 0.87 & 0 & 0 & 0 & 0 & 0 \\
\hline Body care & 0 & -1.55 & -0.99 & 0 & 0 & -1.16 & -0.96 & 0 \\
\hline Other & 0.15 & 0 & 0 & 0 & 0 & 0 & 0.21 & 0 \\
\hline Desired $=$ previous job, 3-digit & 0 & 0 & -0.14 & -0.33 & -0.14 & 0 & 0 & 0 \\
\hline \multicolumn{9}{|l|}{ Additional regional effects by canton } \\
\hline Berne & -0.49 & 0 & 0 & 0 & 0 & 0 & 0 & 0 \\
\hline Lucerne & 0 & 0 & 0 & 0 & -1.08 & 0 & 0 & 0 \\
\hline Schwyz & 0.99 & 0 & 0 & 0 & -1.08 & 0.70 & 0 & 0 \\
\hline Glarus & 0 & 0 & 0 & 0 & 1.52 & 0 & 0 & 0 \\
\hline Zug & -1.55 & 0 & 0 & 0 & -1.99 & 0 & 0 & 0 \\
\hline Freiburg & 0.51 & 0 & 0 & 0 & 0 & 0.24 & 0 & 0 \\
\hline Solothurn & 0 & 0 & 0 & 0 & 0 & -0.91 & 0.41 & 0 \\
\hline Basel-City & -0.51 & -0.28 & 0 & 0 & 0 & 0 & -0.56 & -0.23 \\
\hline St. Gall & 0 & 0 & 0 & 0 & 0 & -0.61 & -0.87 & 0 \\
\hline Graubünden & 0 & 0 & 0.87 & 0 & 0 & -1.45 & 0 & -0.46 \\
\hline Aargau & -0.25 & 0.55 & -0.90 & 0 & 0 & -0.41 & 0 & -0.20 \\
\hline Thurgau & 0 & 0 & 0.73 & 0 & 0 & 0.43 & 0 & 0 \\
\hline Ticino & 0.25 & -0.44 & -1.45 & -2.17 & 0.09 & -0.28 & 1.65 & -0.08 \\
\hline Waadt & 0 & -0.53 & 0 & 0 & 0 & -0.66 & -1.00 & -0.51 \\
\hline Neuenburg & -0.79 & -1.15 & -1.01 & -1.86 & 0 & 0 & 0 & -0.50 \\
\hline Geneva & -1.20 & -0.41 & -0.25 & -0.70 & 0 & -1.47 & -1.83 & -0.68 \\
\hline Jura & -0.59 & -0.64 & 0 & 3.67 & 0 & 0 & 0 & -0.75 \\
\hline Cantonal unemployment rate & -0.28 & -0.01 & 0.28 & 0.38 & -0.06 & -0.08 & -0.28 & -0.02 \\
\hline
\end{tabular}

Table A.4 to be continued 
Table A.4 continued

\begin{tabular}{|c|c|c|c|c|c|c|c|c|}
\hline \multirow[b]{2}{*}{ Variable } & \multirow[t]{2}{*}{$\begin{array}{c}\text { Basic } \\
\text { courses }\end{array}$} & \multirow[t]{2}{*}{$\begin{array}{l}\text { language } \\
\text { courses }\end{array}$} & \multirow[t]{2}{*}{$\begin{array}{l}\text { computer } \\
\text { courses }\end{array}$} & \multirow[t]{2}{*}{$\begin{array}{l}\text { vocat. } \\
\text { training }\end{array}$} & \multirow[t]{2}{*}{$\begin{array}{l}\text { other } \\
\text { training }\end{array}$} & \multicolumn{2}{|c|}{$\begin{array}{l}\text { employment } \\
\text { programme }\end{array}$} & \multirow{2}{*}{$\begin{array}{l}\text { temporary } \\
\text { wage } \\
\text { subsidy }\end{array}$} \\
\hline & & & & & & public & private & \\
\hline \multicolumn{9}{|l|}{ Region (reference category: Zurich) } \\
\hline Eastern & 0.09 & 0.31 & 0.28 & 0.14 & 0.03 & 0.09 & 0.64 & 0.38 \\
\hline Central & 0.19 & 0.41 & 0.88 & 0.61 & 1.76 & 0.20 & 0.81 & 0.10 \\
\hline South-west & 0.96 & -0.44 & -0.99 & -0.86 & 0.24 & 0.57 & 2.14 & 0.60 \\
\hline North-west & 0.40 & -0.12 & 0.48 & -0.04 & -0.02 & -0.37 & 0.94 & 0.29 \\
\hline West & 0.69 & 0.01 & 0.03 & -0.57 & -0.11 & 0.37 & 1.01 & 0.34 \\
\hline \multicolumn{9}{|c|}{ Size of town where worked before (reference categories: $<100^{\prime} 000,<50^{\prime} 000,<20^{\circ} 000,<10^{\prime} 000$ ) } \\
\hline$>200^{\prime} 000$ & 0.28 & 0 & -0.64 & 0 & 0.37 & 0 & 0 & 0 \\
\hline$<30^{\prime} 000$ & 0 & 0 & 0 & 0 & 0 & 0 & 0 & 0.13 \\
\hline$<5000$ & 0 & 0 & 0 & 0 & 0 & 0.10 & 0 & 0 \\
\hline$<2000$ & -0.09 & 0 & -0.18 & 0 & 0 & 0 & 0 & 0 \\
\hline \multicolumn{9}{|c|}{ Region of placement office (reference categories: small city, no information) } \\
\hline Large city & 0 & 0 & 0 & 0 & -0.31 & 0 & -0.16 & 0 \\
\hline Rural & 0 & 0 & -0.42 & 0 & 0 & 0 & 0 & 0 \\
\hline \multicolumn{9}{|c|}{ Long-term unemployment in regional placement office } \\
\hline Inflow to long-term unemployment & 0 & 0 & 4.29 & 0 & 0 & 0 & 2.65 & 0 \\
\hline Outflow from long-term unemployment & 0 & 0 & 4.81 & 0 & 0 & 0 & 3.93 & 0 \\
\hline No information & 0 & 0 & 1.59 & 0 & 0 & 0 & 0.99 & 0 \\
\hline \multicolumn{9}{|l|}{ Sanction days without benefit payment } \\
\hline $\begin{array}{l}\text { Number of sanction days during last } \\
\text { unemployment spell }\end{array}$ & 0 & -0.07 & 0 & 0 & 0 & 0 & 0 & 0 \\
\hline Positive number of sanction days (in \%) & 0 & 0.07 & -0.24 & 0 & 0 & 0 & 0 & -0.11 \\
\hline \multicolumn{9}{|l|}{ Unemployment history } \\
\hline First spell & 0.14 & 0 & 0.23 & 0 & 0 & 0.11 & 0.17 & 0 \\
\hline Number of spells prior to current spell & 0 & -0.17 & 0 & 0 & 0 & 0 & 0 & 0 \\
\hline \multicolumn{9}{|l|}{ Previous programme participation } \\
\hline $\begin{array}{l}\text { Sum of short programs between July } \\
\text { and December } 1997\end{array}$ & 0.15 & 0 & 0.42 & 0.72 & 0.26 & 0 & 0.12 & 0.08 \\
\hline Employment programme before July 97 & 0 & 0 & 0 & 0 & 0 & 0.44 & 0 & 0 \\
\hline $\begin{array}{l}\text { Temporary wage subsidy before July } \\
97\end{array}$ & 0 & 0 & 0 & 0 & 0 & 0 & 0 & 0.53 \\
\hline Begin of programme / 100 & 0.22 & 0.05 & 0.12 & -0.00 & 0.20 & 0.36 & 0.38 & 0.37 \\
\hline \multicolumn{9}{|c|}{ Duration of unemployment spell at beginning of programme } \\
\hline Duration (days) & -0.02 & -1.20 & -1.40 & -1.00 & -0.19 & -0.88 & -0.56 & -2.88 \\
\hline Less than 90 days & 0.03 & -0.15 & -0.33 & -0.46 & -0.27 & -0.47 & -0.28 & -0.14 \\
\hline Less than 180 days & 0.11 & 0 & 0 & 0 & -0.15 & -0.27 & -0.39 & -0.17 \\
\hline Less than 270 days & 0 & 0 & 0 & 0 & 0.15 & -0.15 & 0 & -0.18 \\
\hline Less than 365 days & 0.21 & 0 & 0 & 0 & 0 & 0 & 0 & 0 \\
\hline $\begin{array}{l}\text { Remaining days of "passive regime" on } \\
31.12 .97\end{array}$ & 0 & 0 & 0.30 & 0 & 0 & 0 & 0 & -0.12 \\
\hline
\end{tabular}




\section{Table A.4 continued}

\begin{tabular}{|c|c|c|c|c|c|c|c|c|}
\hline \multirow[b]{2}{*}{ Variable } & \multirow[t]{2}{*}{$\begin{array}{l}\text { Basic } \\
\text { courses }\end{array}$} & \multirow[t]{2}{*}{$\begin{array}{l}\text { language } \\
\text { courses }\end{array}$} & \multirow[t]{2}{*}{$\begin{array}{c}\text { computer } \\
\text { courses }\end{array}$} & \multirow[t]{2}{*}{$\begin{array}{l}\text { vocat. } \\
\text { training }\end{array}$} & \multirow[t]{2}{*}{$\begin{array}{l}\text { other } \\
\text { training }\end{array}$} & \multicolumn{2}{|c|}{$\begin{array}{l}\text { employment } \\
\text { programme }\end{array}$} & \multirow{2}{*}{$\begin{array}{l}\text { temporary } \\
\text { wage } \\
\text { subsidy }\end{array}$} \\
\hline & & & & & & public & private & \\
\hline \multicolumn{9}{|l|}{ Employment history from social security data } \\
\hline Never unemployed & 0 & 0 & 0.34 & 0 & 0 & 0 & 0 & 0 \\
\hline Month of entry into social security system & 0 & 0.84 & 0 & 0 & 0.29 & 0 & 0 & 0 \\
\hline Mean duration of employ. spell in months & 0 & 0.16 & 0 & 0 & 0 & 0 & -0.19 & 0 \\
\hline Mean duration of unemploy. spell in months & 0 & 2.14 & 4.28 & 0 & 0 & 0 & 0 & 0 \\
\hline Standard deviation of wages / 1000 & -0.15 & -0.15 & -0.14 & -0.07 & -0.19 & -0.19 & -0.25 & -0.13 \\
\hline Proportion of time unemployed, in \% & -0.13 & -1.62 & -1.63 & -1.51 & -0.58 & 0.45 & 0.62 & -0.67 \\
\hline Proportion of time employed, in \% & 0 & 0 & 0 & 0 & 0 & 0 & 0 & 0.79 \\
\hline
\end{tabular}

Note: $\quad$ Simulated maximum likelihood estimates using the GHK simulator (100 draws in simulator for each observation and choice equation). Coefficients of the category NONPARTICIPATION are normalised to zero. All equations include a constant. Inference is based on the outer product of the gradient estimate of the covariance matrix of the coefficients ignoring simulation error. $N=19603$. Value of log-likelihood function: -31744.08 .

Bold numbers indicate significance at the $1 \%$ level (2-sided test), numbers in italics relate to the $5 \%$ level. If not stated otherwise, all information in the variables relates to the last day in December 1997.

Table A.5: Estimated covariance and correlation matrices of the error terms in the multinomial probit model

\begin{tabular}{|c|c|c|c|c|c|c|c|c|c|c|c|c|c|c|c|c|c|c|}
\hline & \multirow{2}{*}{\multicolumn{2}{|c|}{ Nonpart. }} & \multirow{2}{*}{\multicolumn{2}{|c|}{$\begin{array}{c}\text { basic } \\
\text { courses }\end{array}$}} & \multirow{2}{*}{\multicolumn{2}{|c|}{$\begin{array}{l}\text { language } \\
\text { courses }\end{array}$}} & \multirow{2}{*}{\multicolumn{2}{|c|}{$\begin{array}{l}\text { computer } \\
\text { courses }\end{array}$}} & \multirow{2}{*}{\multicolumn{2}{|c|}{$\begin{array}{l}\text { vocat. } \\
\text { training }\end{array}$}} & \multirow{2}{*}{\multicolumn{2}{|c|}{$\begin{array}{c}\text { other } \\
\text { training }\end{array}$}} & \multicolumn{4}{|c|}{$\begin{array}{l}\text { employment } \\
\text { programmes }\end{array}$} & \multirow{2}{*}{\multicolumn{2}{|c|}{$\begin{array}{l}\text { temporary } \\
\text { wage } \\
\text { subsidy }\end{array}$}} \\
\hline & & & & & & & & & & & & & & & priv & & & \\
\hline & Coef & t-val & coef & t-val & coef & t-val & coef & t-val & coef & t-val & coef & t-val & coef & t-val & coef & t-val & coef & $\mathrm{t}$-val \\
\hline \multicolumn{19}{|c|}{ Covariance matrix a) } \\
\hline NONP & 1 & & 0 & - & 0 & - & 0 & - & 0 & - & 0 & - & 0 & - & 0 & - & 0 & - \\
\hline BAC & & & 1 & & -0.19 & 0.17 & -0.78 & 0.58 & -0.27 & 1.63 & 0 & - & 0 & - & 0 & - & 0 & - \\
\hline LAC & & & & & 1.04 & & -1.61 & 0.64 & -0.50 & 1.23 & 0 & - & 0 & - & 0 & - & 0 & - \\
\hline $\operatorname{coc}$ & & & & & & & 4.71 & & -1.44 & 1.59 & 0 & - & 0 & - & 0 & - & 0 & - \\
\hline FVT & & & & & & & & & 8.24 & & 0 & - & 0 & - & 0 & - & 0 & - \\
\hline OTC & & & & & & & & & & & 1 & & 0 & - & 0 & - & 0 & - \\
\hline TE-PU & & & & & & & & & & & & & 1 & & 0.53 & 0.22 & 0.04 & 0.24 \\
\hline TE-PR & & & & & & & & & & & & & & & 1.28 & & -0.29 & 0.25 \\
\hline TEMP & & & & & & & & & & & & & & & & & 2.19 & 1.85 \\
\hline \multicolumn{19}{|c|}{ Correlation matrix ${ }^{\text {a) }} \times 100$} \\
\hline NONP & 100 & & 0 & & 0 & & 0 & & 0 & & 0 & & 0 & & 0 & & 0 & \\
\hline BAC & & & 100 & & -19 & & -36 & & -9.6 & & 0 & & 0 & & 0 & & 0 & \\
\hline LAC & & & & & 100 & & -73 & & -17 & & 0 & & 0 & & 0 & & 0 & \\
\hline $\mathrm{COC}$ & & & & & & & 100 & & -23 & & 0 & & 0 & & 0 & & 0 & \\
\hline FVT & & & & & & & & & 100 & & 0 & & 0 & & 0 & & 0 & \\
\hline OTC & & & & & & & & & & & 100 & & 0 & & 0 & & 0 & \\
\hline TE-PU & & & & & & & & & & & & & 100 & & 47 & & 2.9 & \\
\hline TE-PR & & & & & & & & & & & & & & & 100 & & -17 & \\
\hline TEMP & & & & & & & & & & & & & & & & & 100 & \\
\hline Note: & & & & & are e & ma & & sure $t$ & & & & & & & & $\mathrm{de}$ & e. t & alues \\
\hline
\end{tabular}




\section{Appendix A.4: Common support}

Table A.6: Comparison of means of selected variables in the subsample used for matching and the subsample not used for matching because of insufficient overlap

\begin{tabular}{|c|c|c|}
\hline Variable & $\begin{array}{l}\text { Observations used } \\
\text { for matching }\end{array}$ & $\begin{array}{l}\text { Observations not } \\
\text { used for matching }\end{array}$ \\
\hline Number of observations & 16533 & 2773 \\
\hline & \multicolumn{2}{|c|}{ shares in \% } \\
\hline Female & 42 & 53 \\
\hline \multicolumn{3}{|l|}{ Mother tongue } \\
\hline Not G///F & 36 & 48 \\
\hline \multicolumn{3}{|l|}{ Chances to find $a j o b$} \\
\hline Special case & 2 & 6 \\
\hline \multicolumn{3}{|l|}{ Qualification } \\
\hline Unskilled & 29 & 41 \\
\hline \multicolumn{3}{|l|}{ Previous Occupation } \\
\hline Metals & 8 & 4 \\
\hline Restaurants & 15 & 20 \\
\hline Office and computer & 15 & 9 \\
\hline Retail trade & 9 & 5 \\
\hline \multicolumn{3}{|l|}{ Job position } \\
\hline Low & 37 & 48 \\
\hline \multicolumn{3}{|l|}{ Previous industry sector } \\
\hline Trade & 15 & 11 \\
\hline Restaurants, catering & 13 & 21 \\
\hline Industry unemployment rate in $\%, 1 / 98$ & 6.4 & 7.3 \\
\hline \multicolumn{3}{|l|}{ Region } \\
\hline Eastern & 5 & 10 \\
\hline South-west & 28 & 19 \\
\hline Central & 18 & 26 \\
\hline \multicolumn{3}{|l|}{ Region of placement office } \\
\hline Large city & 44 & 30 \\
\hline \multicolumn{3}{|l|}{ Social security data } \\
\hline Month of entry into social security system & 12 & 20 \\
\hline
\end{tabular}




\section{Appendix A.5: More information about outcome variables and sample sizes}

Table A.7: Descriptive statistics of employment and non-employment and corresponding sample sizes

\begin{tabular}{|c|c|c|c|c|c|c|c|c|c|c|c|c|c|c|c|c|c|c|}
\hline \multirow[b]{3}{*}{ Day } & \multirow{2}{*}{\multicolumn{2}{|c|}{ Nonpart. }} & \multirow{2}{*}{\multicolumn{2}{|c|}{$\begin{array}{l}\text { basic } \\
\text { courses }\end{array}$}} & \multirow{2}{*}{\multicolumn{2}{|c|}{$\begin{array}{l}\text { language } \\
\text { courses }\end{array}$}} & \multirow{2}{*}{\multicolumn{2}{|c|}{$\begin{array}{l}\text { comp. } \\
\text { courses }\end{array}$}} & \multirow{2}{*}{\multicolumn{2}{|c|}{$\begin{array}{l}\text { vocat. } \\
\text { training }\end{array}$}} & \multirow{2}{*}{\multicolumn{2}{|c|}{$\begin{array}{l}\text { other } \\
\text { training }\end{array}$}} & \multicolumn{4}{|c|}{$\begin{array}{l}\text { employment } \\
\text { programme }\end{array}$} & \multirow{2}{*}{\multicolumn{2}{|c|}{$\begin{array}{l}\text { temporary } \\
\text { wage } \\
\text { subsidy }\end{array}$}} \\
\hline & & & & & & & & & & & & & \multicolumn{2}{|c|}{ public } & \multicolumn{2}{|c|}{ private } & & \\
\hline & mean & $N$ & mean & $N$ & mean & $N$ & mean & $n N$ & mean & $N$ & mean & $N$ & mean & $N$ & mean & $N$ & mean & $N$ \\
\hline \multirow{2}{*}{\multicolumn{19}{|c|}{ Calendar time (day 1 is Jan, 1,1998 , observed after begin of programme) }} \\
\hline \multicolumn{8}{|c|}{ Employed } & & & & & & & & & & & \\
\hline 181 & 33 & 5186 & 17 & 1078 & 16 & 1205 & 21 & 1084 & 421 & 347 & 18 & 351 & 11 & 720 & 13 & 822 & 30 & 3128 \\
\hline 271 & 39 & 5702 & 24 & 1200 & 21 & 1310 & 29 & 1168 & $\begin{array}{l}32 \\
32\end{array}$ & 377 & 25 & 390 & 16 & 883 & 15 & 1014 & 39 & 3427 \\
\hline 361 & 35 & 5946 & 27 & 1269 & 24 & 1363 & 36 & 1223 & $3 \quad 35$ & 392 & 31 & 424 & 19 & 958 & 18 & 1110 & 40 & 3700 \\
\hline 451 & 39 & 5987 & 32 & 1290 & 29 & 1380 & 44 & 1237 & $7 \quad 42$ & 395 & 43 & 433 & 29 & 978 & 25 & 1133 & 49 & 3700 \\
\hline \multicolumn{19}{|c|}{ Not unemployed } \\
\hline 181 & 44 & * & 22 & * & 21 & * & 26 & * & 25 & * & 24 & * & 15 & * & 17 & * & 38 & * \\
\hline 271 & 51 & & 29 & & 25 & & 33 & & 35 & & 31 & & 20 & & 19 & & 44 & \\
\hline 361 & 51 & & 35 & & 30 & & 43 & & 41 & & 37 & & 25 & & 25 & & 46 & \\
\hline 451 & 61 & & 45 & & 42 & & 56 & & 51 & & 55 & & 40 & & 38 & & 59 & \\
\hline
\end{tabular}

Days after begin of programme

\begin{tabular}{|c|c|c|c|c|c|c|c|c|c|c|c|c|c|c|c|c|c|c|}
\hline \multicolumn{19}{|c|}{ Employed } \\
\hline 1 & 4 & 5987 & 1 & 1290 & 0 & 1380 & 1 & 1237 & 0 & 395 & 0 & 433 & 0 & 978 & 0 & 1133 & 3 & 3700 \\
\hline 91 & 28 & 5955 & 12 & 1275 & 10 & 1367 & 15 & 1229 & 14 & 393 & 14 & 426 & 8 & 967 & 9 & 1122 & 27 & 3700 \\
\hline 181 & 38 & 5784 & 23 & 1218 & 20 & 1322 & 27 & 1180 & 30 & 380 & 26 & 397 & 19 & 900 & 17 & 1036 & 41 & 3545 \\
\hline 271 & 41 & 5235 & 31 & 1086 & 27 & 1219 & 37 & 1091 & 42 & 349 & 38 & 353 & 26 & 757 & 24 & 851 & 48 & 3128 \\
\hline 361 & 42 & 4169 & 36 & 834 & 31 & 1007 & 46 & 898 & 44 & 286 & 43 & 258 & 33 & 466 & 31 & 547 & 52 & 2258 \\
\hline 451 & 48 & 417 & 33 & 144 & 40 & 219 & 51 & 201 & 61 & 38 & 60 & 45 & 38 & 29 & 36 & 39 & 59 & 608 \\
\hline \multicolumn{19}{|c|}{ Not unemployed } \\
\hline 1 & 4 & * & 1 & * & 0 & * & 1 & $*$ & 0 & * & 1 & * & 0 & * & 0 & * & 4 & * \\
\hline 91 & 37 & & 13 & & 12 & & 16 & & 15 & & 17 & & 10 & & 10 & & 29 & \\
\hline 181 & 52 & & 27 & & 24 & & 32 & & 33 & & 32 & & 24 & & 23 & & 48 & \\
\hline 271 & 58 & & 39 & & 33 & & 44 & & 48 & & 44 & & 34 & & 33 & & 56 & \\
\hline 361 & 61 & & 48 & & 41 & & 57 & & 50 & & 55 & & 43 & & 43 & & 61 & \\
\hline 451 & 68 & & 49 & & 55 & & 65 & & 66 & & 69 & & 52 & & 54 & & 69 & \\
\hline
\end{tabular}

Note: $\quad$ Mean: Sample mean in \%. N: Sample size that could be used for evaluation. Results available on daily basis. * See entries in column directly above this column. Not unemployed is defined as 1 - (registered as unemployed). 


\section{Appendix B: Additional results}

\section{Appendix B.1: Mean results}

Table B.1: Average effects measured as difference in employment rates end of March 1999 in \%points

\begin{tabular}{|c|c|c|c|c|c|c|c|c|c|}
\hline \multirow{2}{*}{$\begin{array}{l} \\
m^{l}\end{array}$} & \multirow[t]{2}{*}{ Nonpart. } & \multirow[t]{2}{*}{$\begin{array}{l}\text { basic } \\
\text { courses }\end{array}$} & \multirow[t]{2}{*}{$\begin{array}{c}\text { language } \\
\text { course }\end{array}$} & \multirow[t]{2}{*}{$\begin{array}{l}\text { computer } \\
\text { course }\end{array}$} & \multirow[t]{2}{*}{$\begin{array}{l}\text { vocat. } \\
\text { training }\end{array}$} & \multirow[t]{2}{*}{$\begin{array}{l}\text { other } \\
\text { training }\end{array}$} & \multicolumn{2}{|c|}{$\begin{array}{l}\text { employment } \\
\text { programme }\end{array}$} & \multirow{2}{*}{$\begin{array}{c}\text { temporary } \\
\text { wage } \\
\text { subsidy }\end{array}$} \\
\hline & & & & & & & public & private & \\
\hline \multicolumn{10}{|c|}{ average effect for participants in programme $m\left(\theta_{0}^{m, l}\right)$} \\
\hline NONP & 39 & 9.1 & 5.8 & & & -5.9 & 6.5 & 8.6 & -9.0 \\
\hline BAC & -9.7 & 32 & & & -7.3 & -16.2 & & & -15.9 \\
\hline LAC & -8.3 & & 29 & & -16.0 & -17.5 & & & -21.6 \\
\hline $\mathrm{COC}$ & -4.6 & 11.2 & & 44 & & -8.5 & & & -10.2 \\
\hline FVT & & 14.7 & & & 42 & & 9.9 & 13.7 & -13.4 \\
\hline OTC & & 9.5 & 12.0 & & & 43 & 11.8 & 12.7 & -6.5 \\
\hline TE-PU & & & & & -11.6 & -10.9 & 29 & & -15.0 \\
\hline TE-PR & -7.3 & & & & & -18.4 & & 25 & -19.6 \\
\hline TEMP & 7.5 & 18.8 & 13.1 & 9.9 & & & 14.9 & 16.1 & 49 \\
\hline Composite & 3.8 & -8.6 & -10.3 & -3.0 & -0.2 & 3.0 & -4.7 & -8.7 & 10.5 \\
\hline \multicolumn{10}{|c|}{ average effect $\left(\gamma_{0}^{m, l}\right)$} \\
\hline NONP & 39 & 9.4 & 6.7 & & & -7.0 & 6.8 & 8.2 & -9.1 \\
\hline BAC & -9.4 & 32 & & -6.3 & -10.4 & -16.4 & & & -18.5 \\
\hline LAC & -6.7 & & 29 & & -7.7 & -13.7 & & & -15.8 \\
\hline $\mathrm{COC}$ & & 6.3 & & 44 & & -10.0 & & 5.1 & -12.2 \\
\hline FVT & & 10.4 & 7.7 & & 42 & & 7.8 & 9.2 & -8.1 \\
\hline OTC & 7.0 & 16.4 & 13.7 & 10.0 & & 43 & 13.7 & 15.1 & \\
\hline TE-PU & -6.8 & & & & & -13.7 & 29 & & -15.9 \\
\hline TE-PR & -8.2 & & & -5.1 & & -15.1 & & 25 & -17.3 \\
\hline TEMP & 9.1 & 18.5 & 15.8 & 12.2 & & & 15.9 & 17.3 & 49 \\
\hline Composite & 2.4 & -13.2 & -14.2 & -5.9 & -2.1 & 2.5 & -8.5 & -13.0 & 12.0 \\
\hline
\end{tabular}


Figure B.1: Average effects of LANGUAGE COURSES for participants in LAC

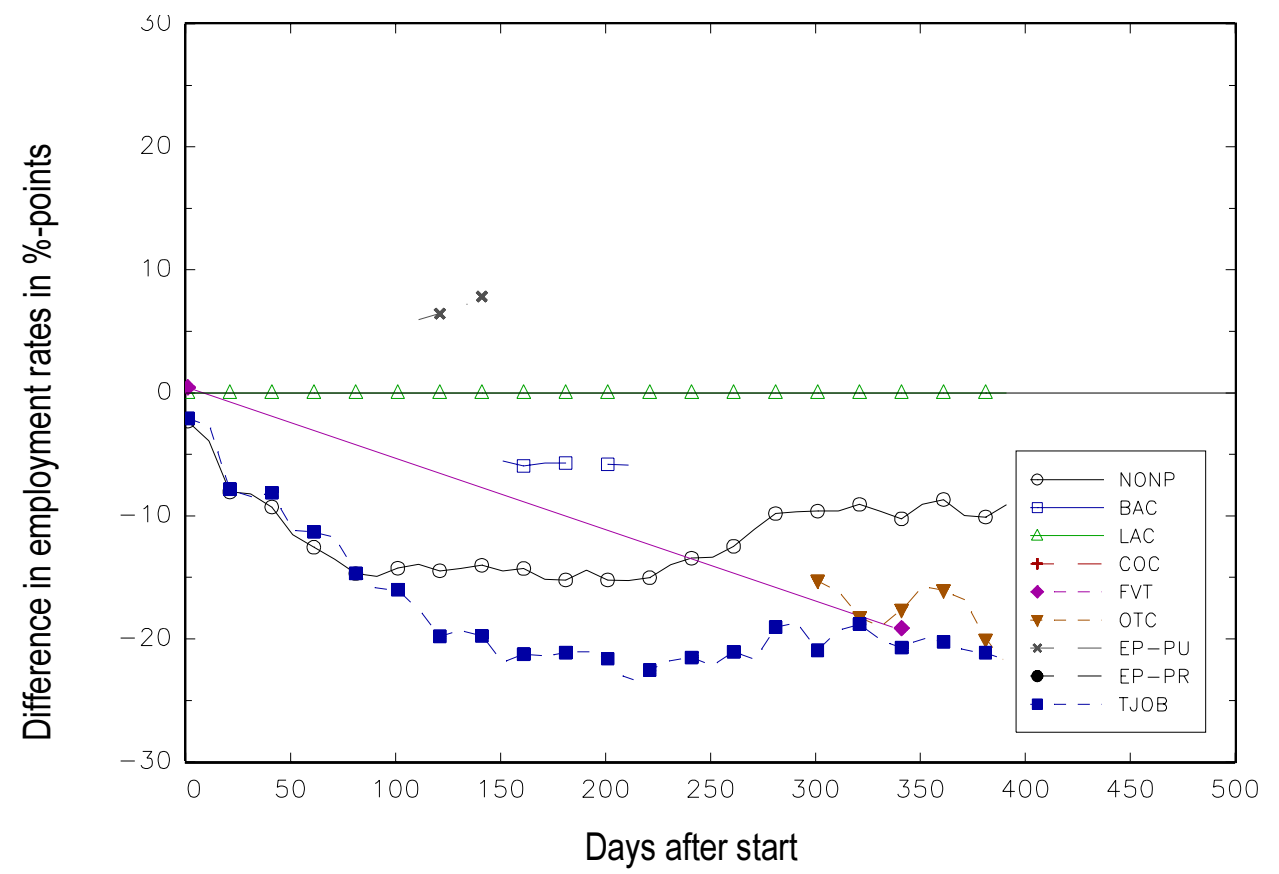

Note: See note below Figure B.1.

Figure B.2: Average effects of OTHER TRAINING for participants in OTC

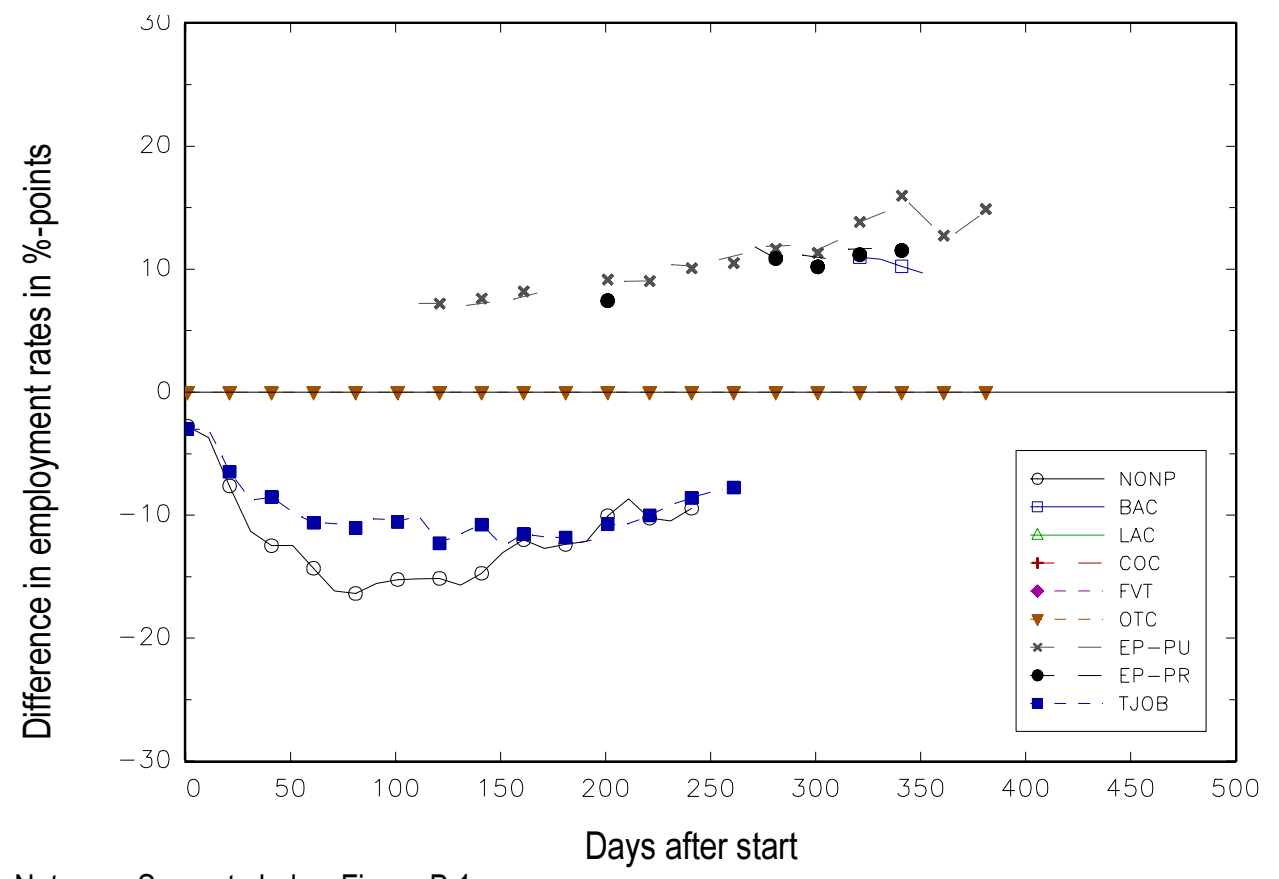

Note: See note below Figure B.1. 
Figure B.3: Average effects of EMPLOYMENT PROGRAMME (PRIVATE) for participants in EP-PR

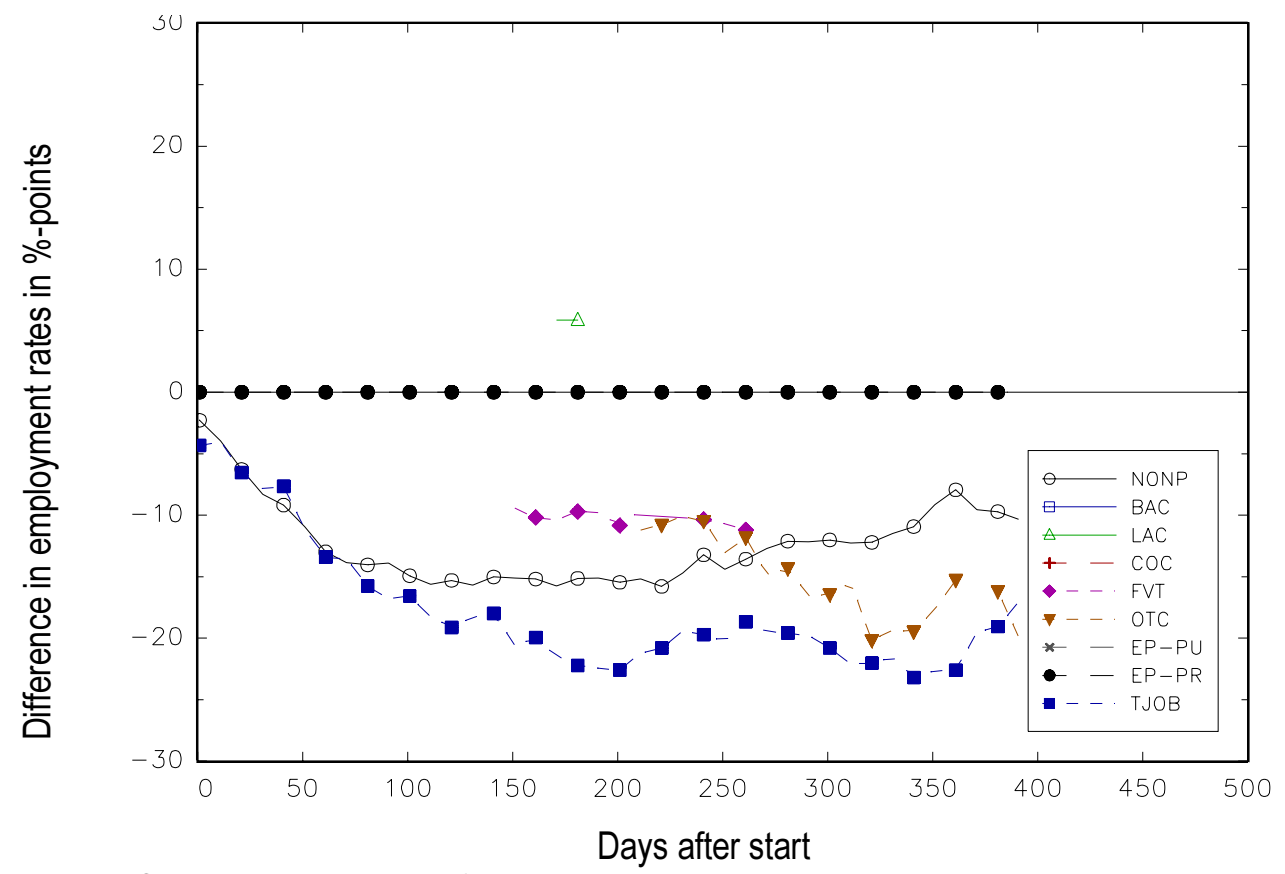

Note: See note below Figure B.1. 


\section{Appendix B.2: $\quad$ Heterogeneity in subgroups defined by attributes}

Figure B4.: Effect heterogeneity with respect to gender: The comparison to nonparticipants

Figure B.4a: Population effects for men

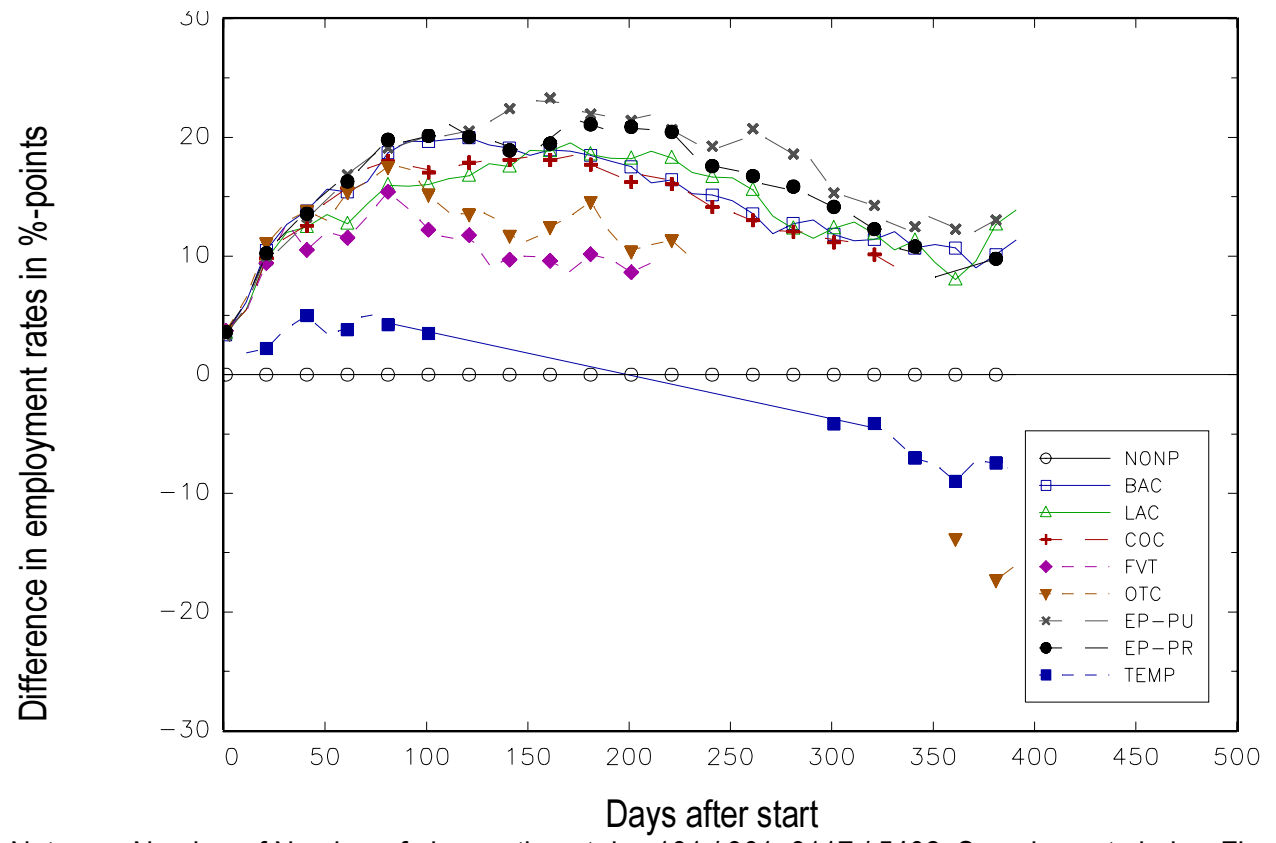

Note: $\quad$ Number of Number of observation at day 181 / 361: 8117 / 5402. See also note below Figure 8.

Figure B.4b: Population effects for women

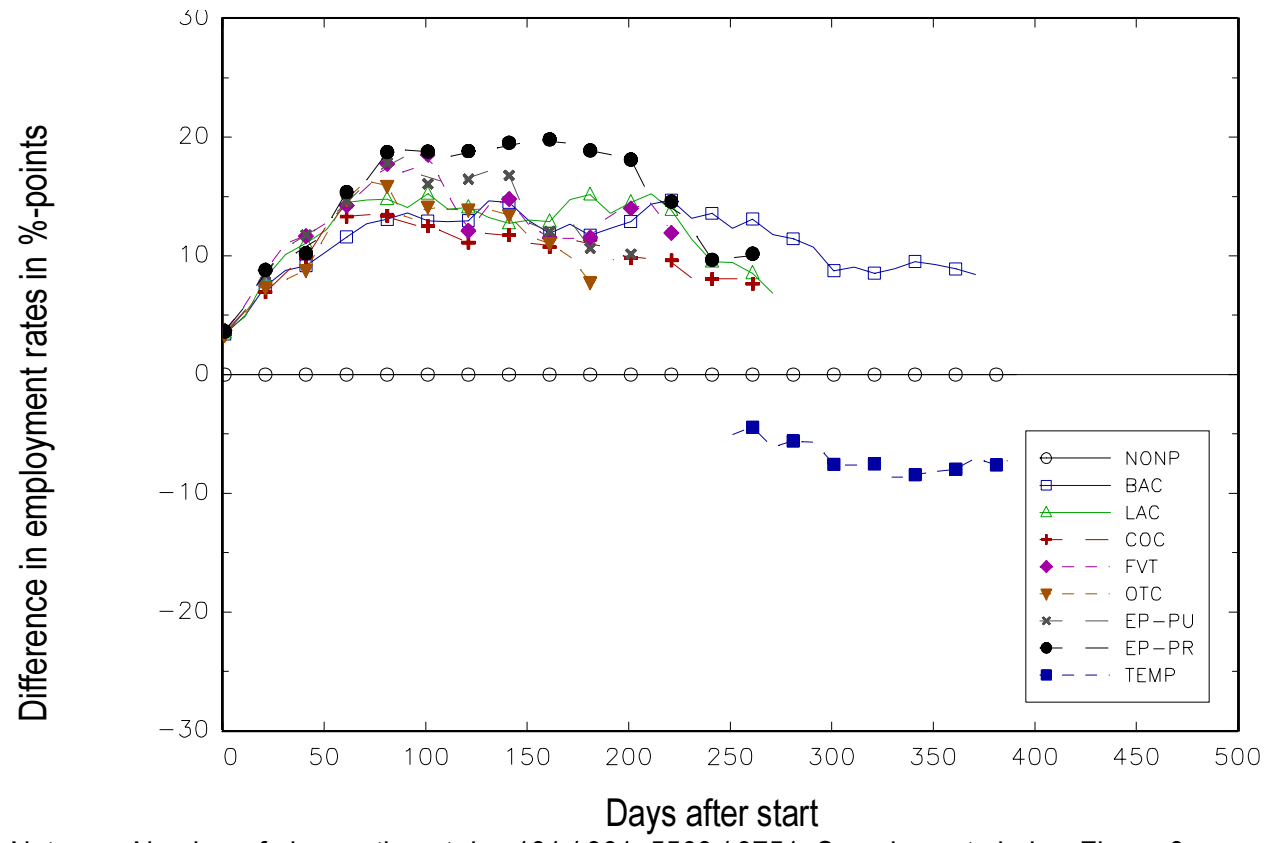

Note: $\quad$ Number of observation at day 181 / 361: 5568 / 3751. See also note below Figure 8. 
Figure B.5: Effect heterogeneity with respect to nationality: The comparison to nonparticipants

Figure B.5a: Population effects for Swiss citizens

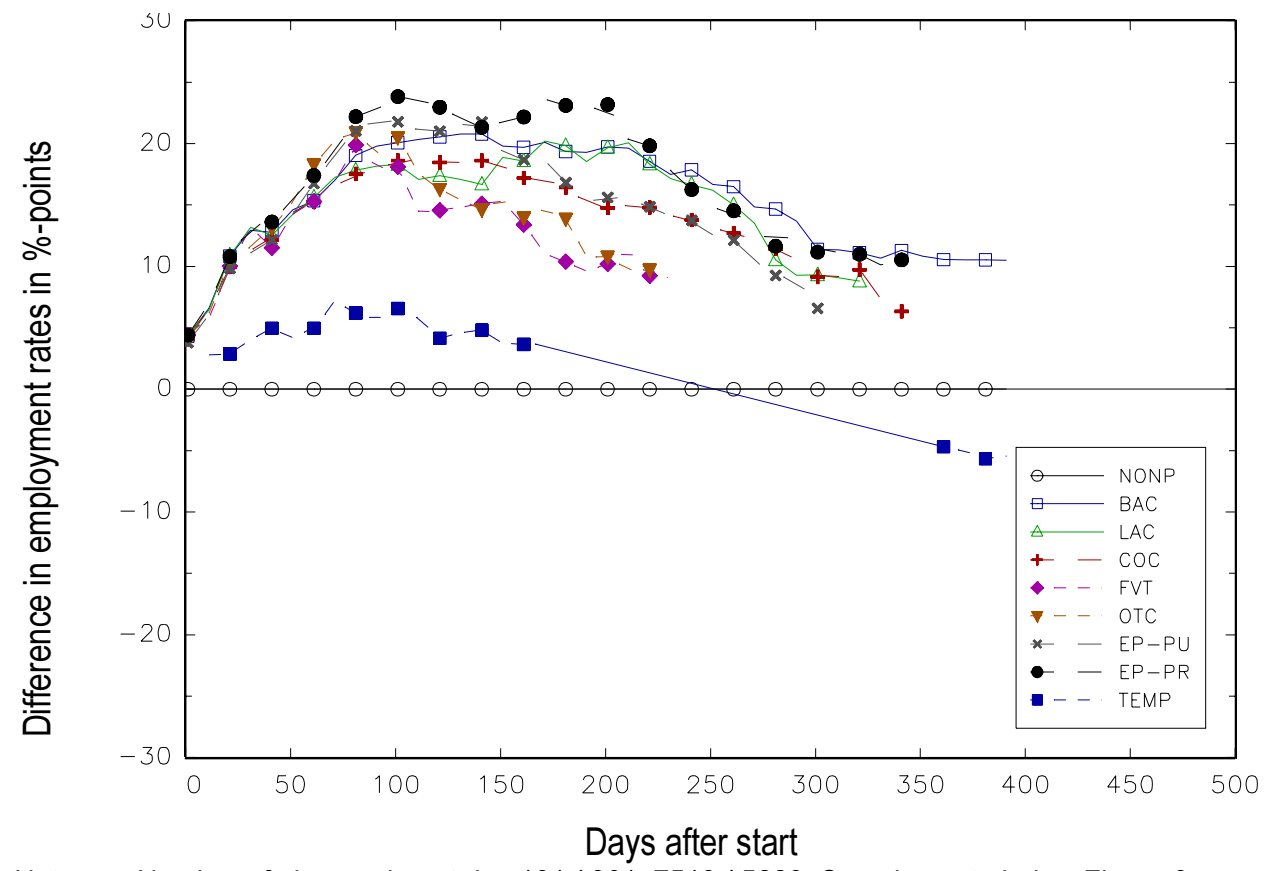

Note: $\quad$ Number of observation at day 181 / 361: 7513 / 5223. See also note below Figure 8.

Figure B.5b: Population effects for foreigners

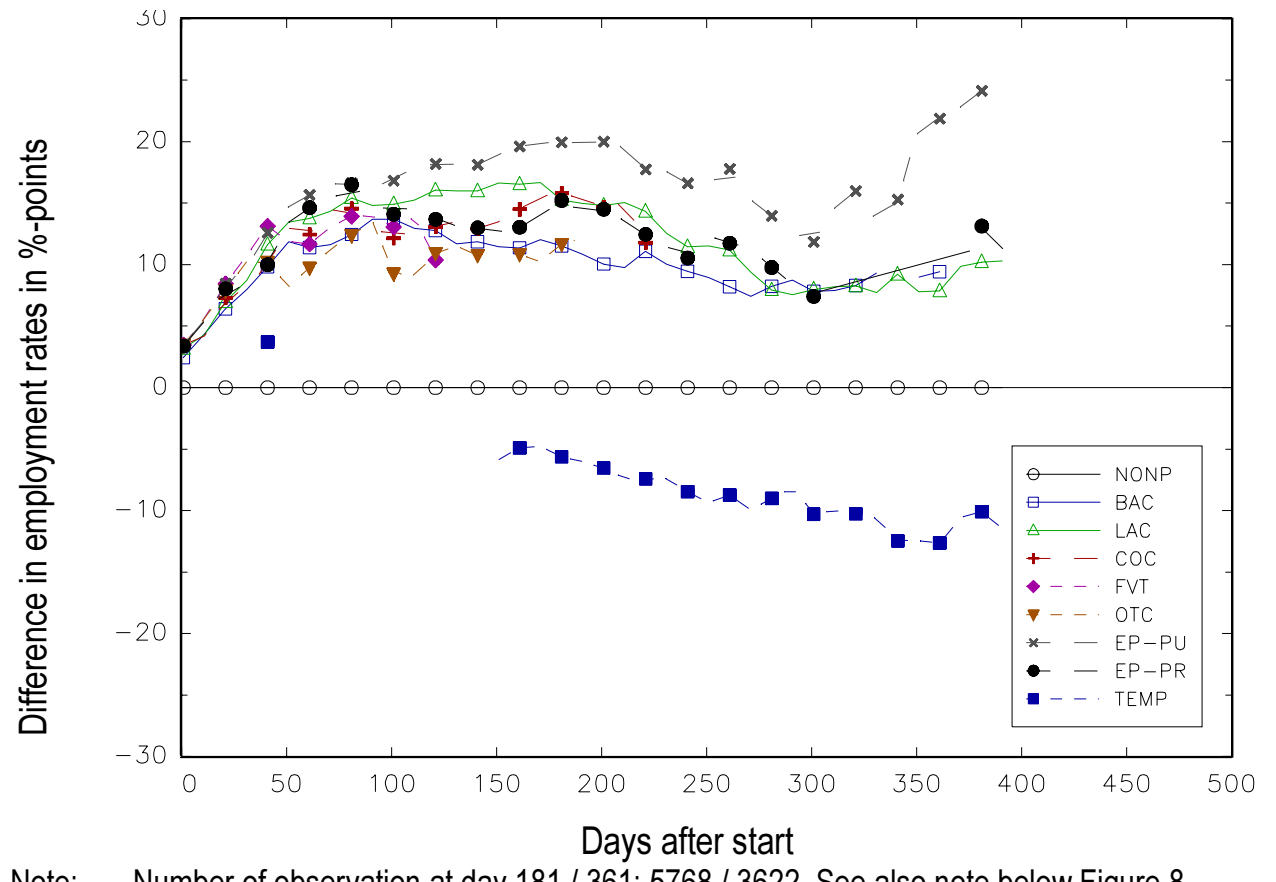

Note: $\quad$ Number of observation at day 181 / 361: 5768 / 3622. See also note below Figure 8 . 
Figure B.6: Effect heterogeneity with respect to short term unemployment history: The comparison to nonparticipants

Figure B.6a: Population effects for people with less than 270 days of unemployment before start

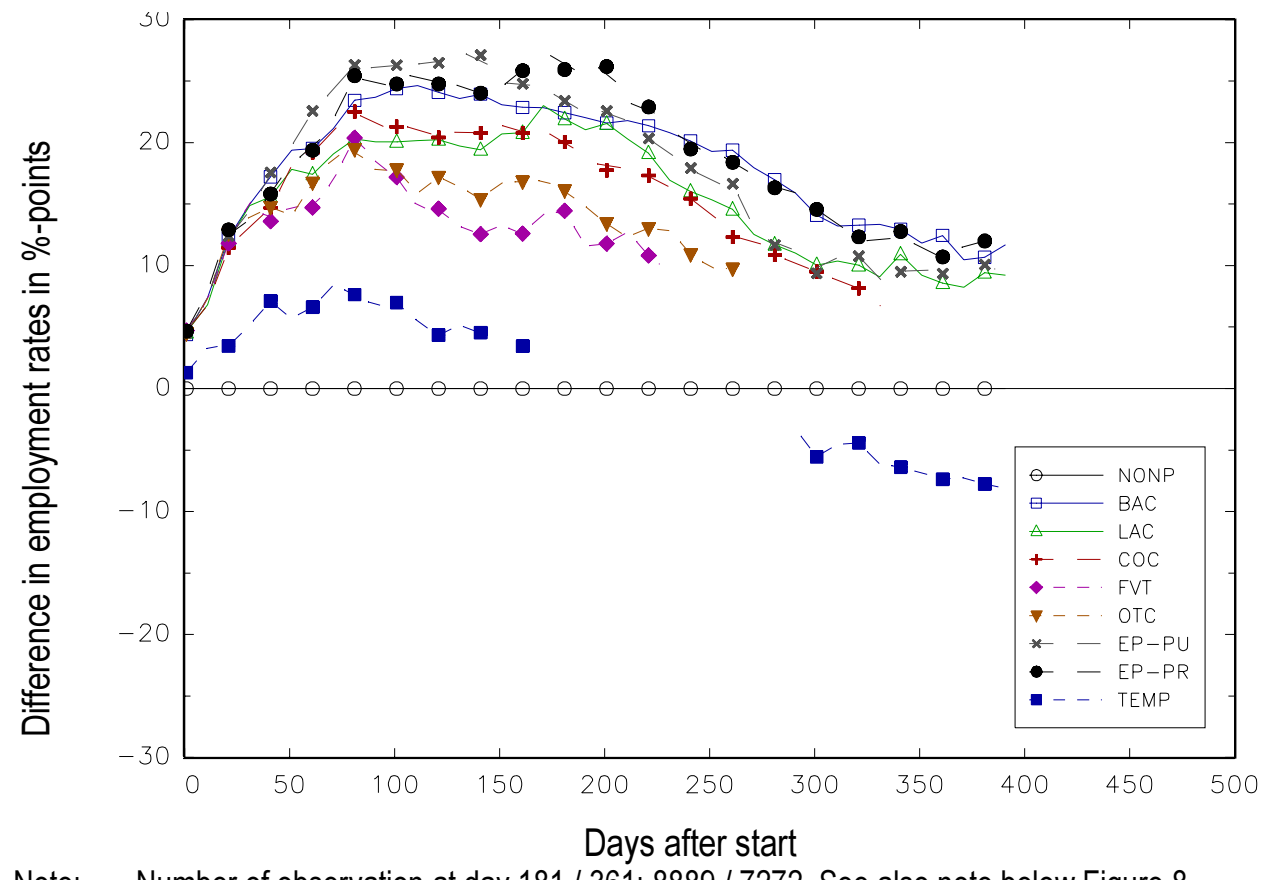

Note: $\quad$ Number of observation at day 181 / 361: 8889 / 7272 . See also note below Figure 8 .

Figure B.6b: Population effects for people with more than 270 days of unemployment before start

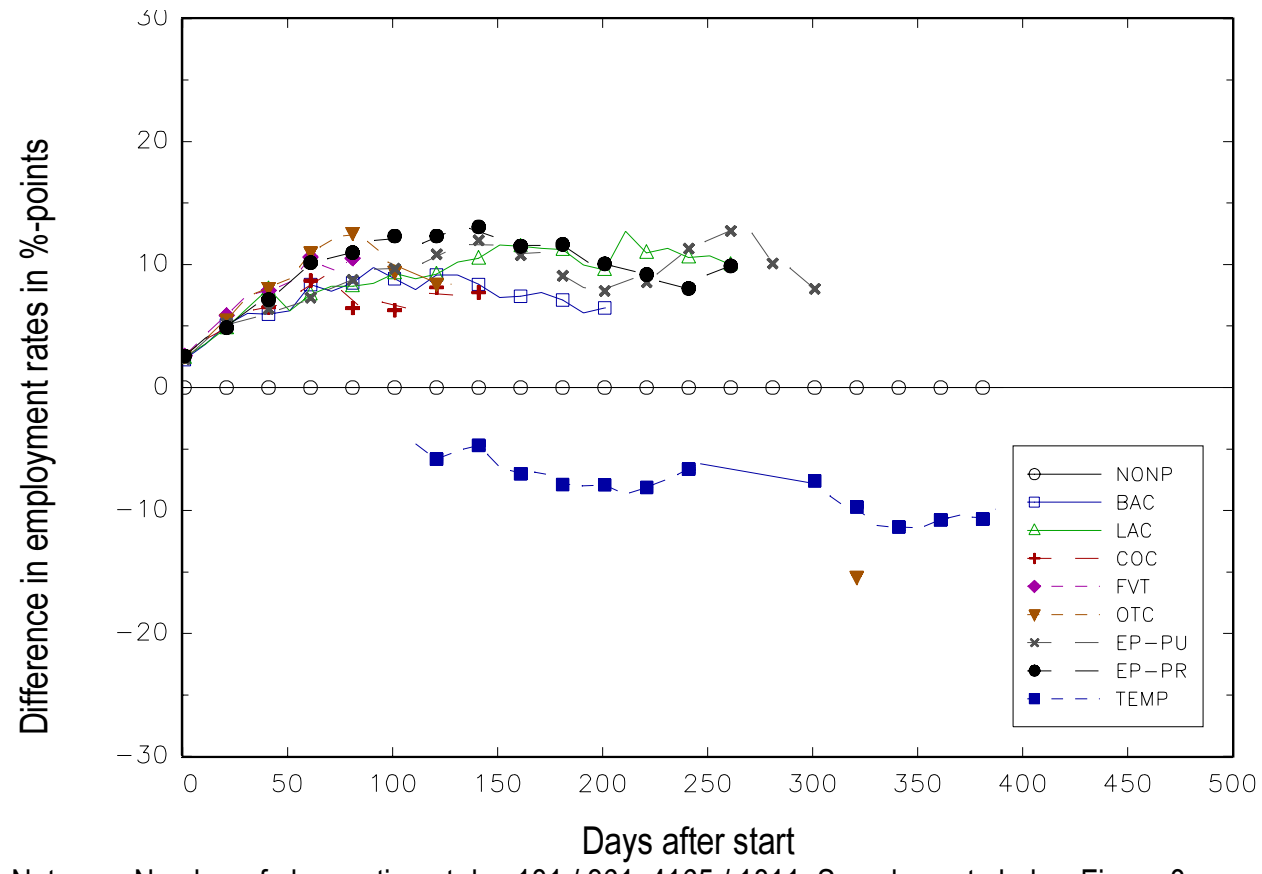

Note: Number of observation at day 181 / 361: 4165 / 1811. See also note below Figure 8. 


\section{Appendix B.3: $\quad$ Some sensitivity checks}

Figure B.7: Registered as unemployed as measure for the labour market outcome

Figure B.7a: Composite effects for the respective participants

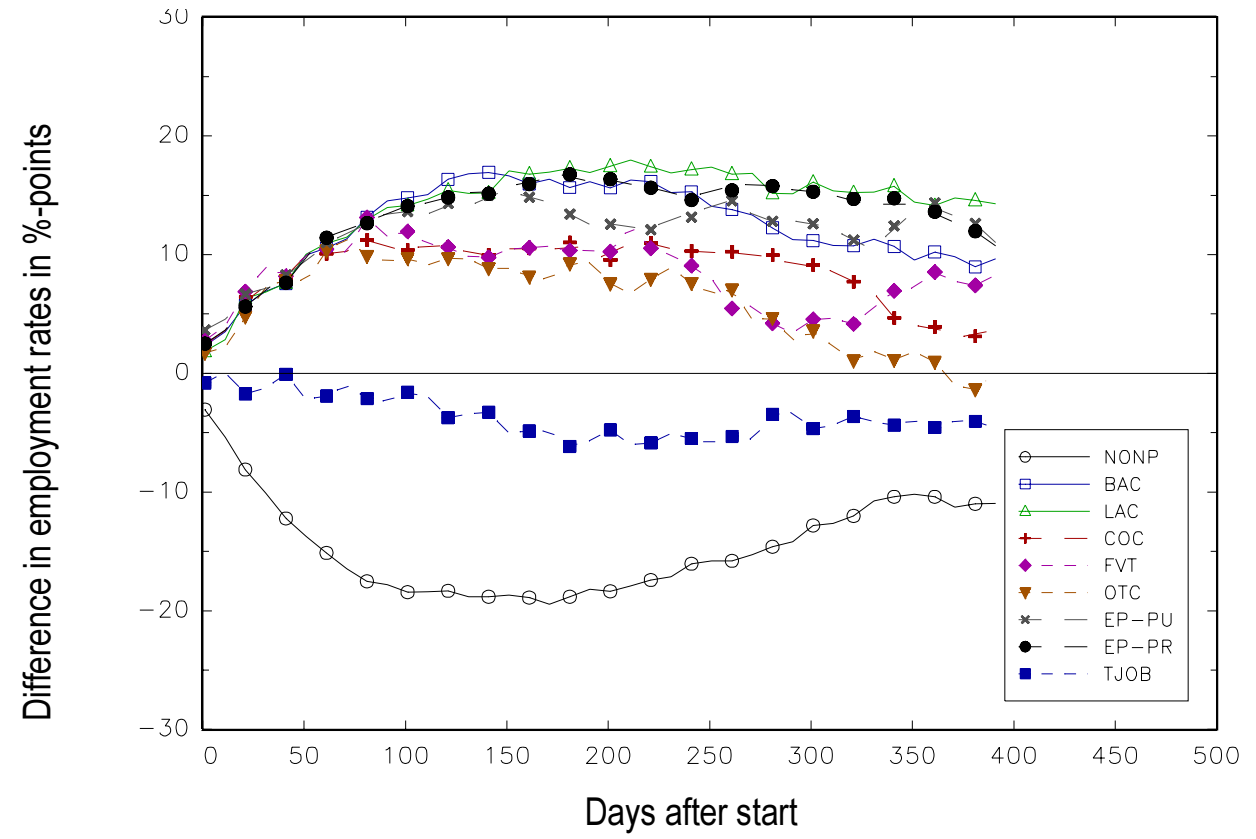

Note: See also note below Figure 8.

Figure B.7b: The comparison to nonparticipation for the population

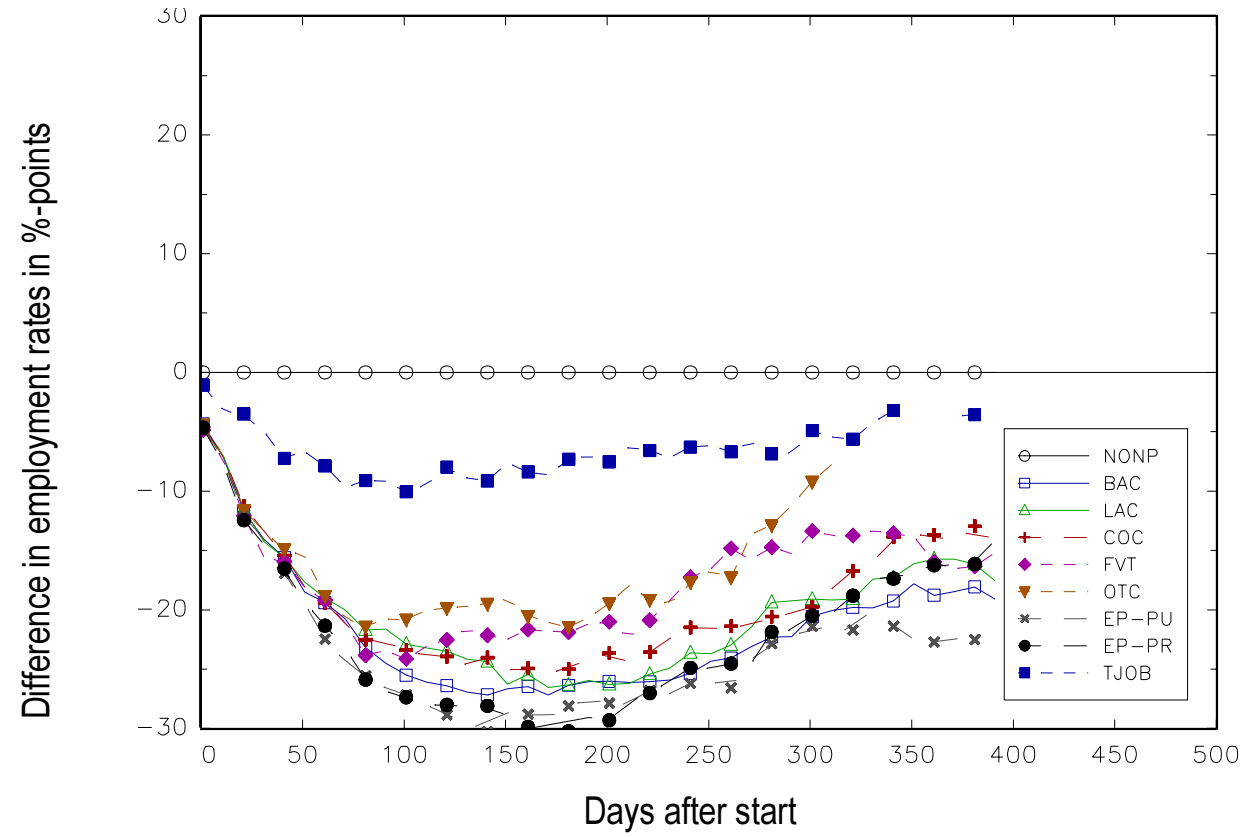

Note: See also note below Figure 8. 
Figure B.8: Employment after the end of the programme as measure for the labour market outcome

Figure B.8a: Composite effects for the respective participants

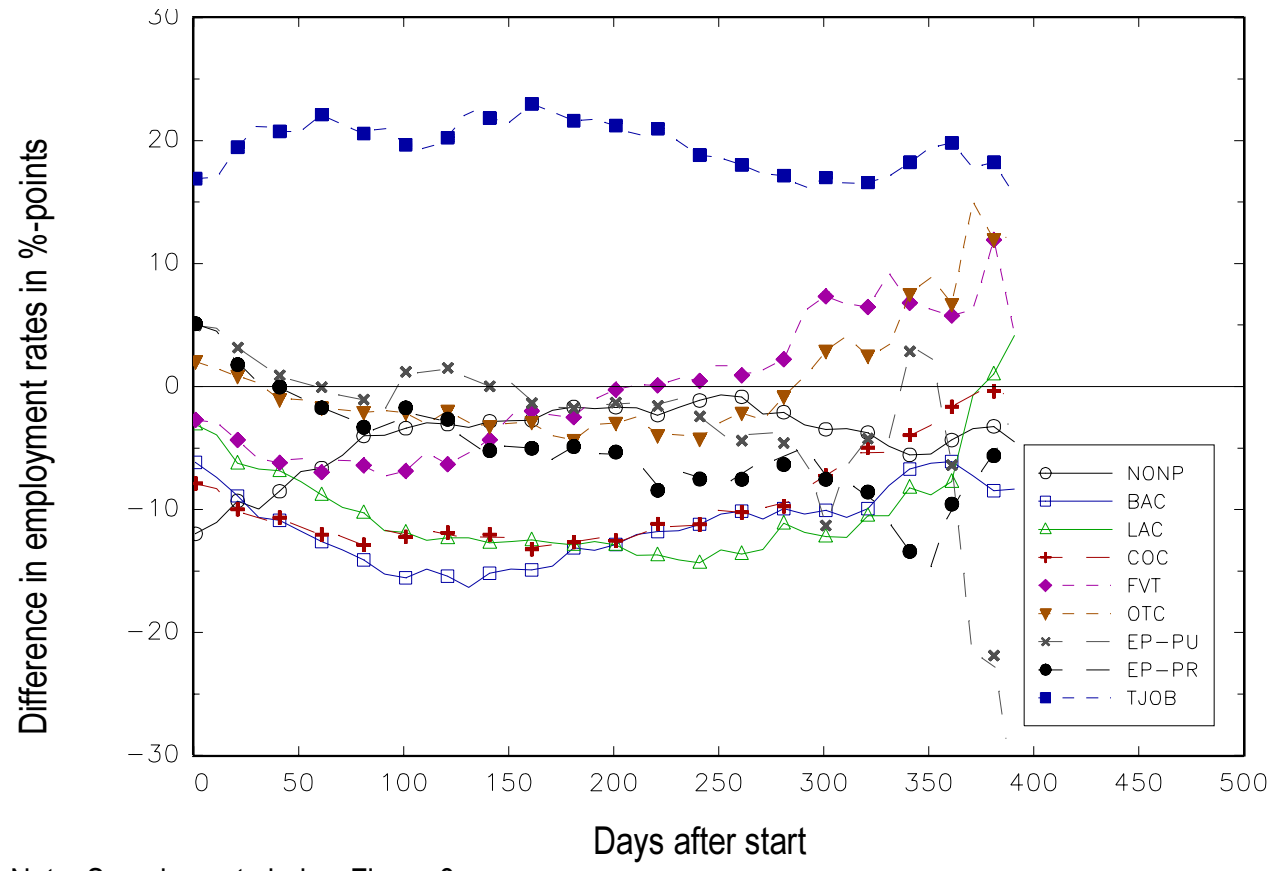

Note: See also note below Figure 8.

Figure B.8b: The comparison to nonparticipation for the population

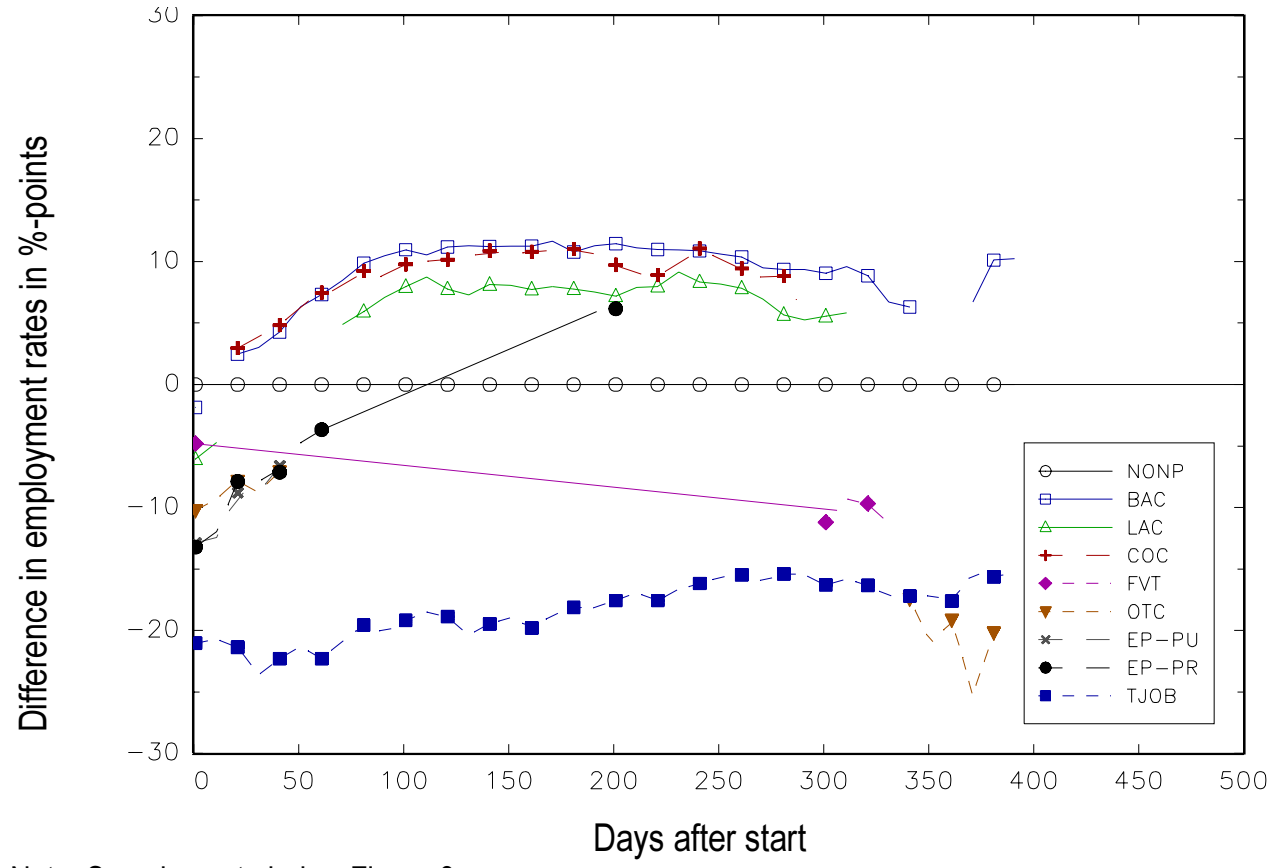

Note: See also note below Figure 8 . 
Figure B.9:Calendar time instead of process time

Figure B.9a: Composite effects for the respective participants

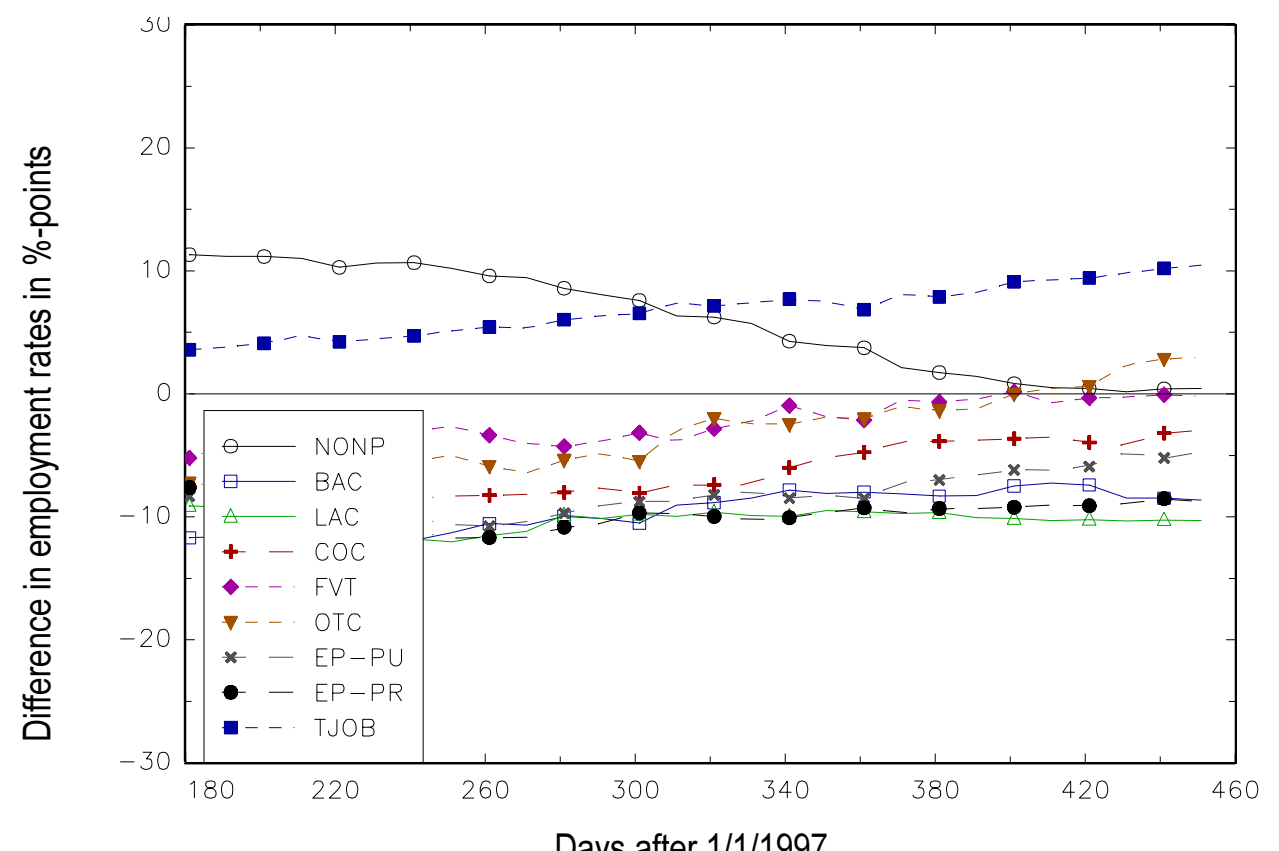

Note: See also note below Figure 8. Only observations after the start of the programme are used.

Figure B.9b: The comparison to nonparticipation for the population

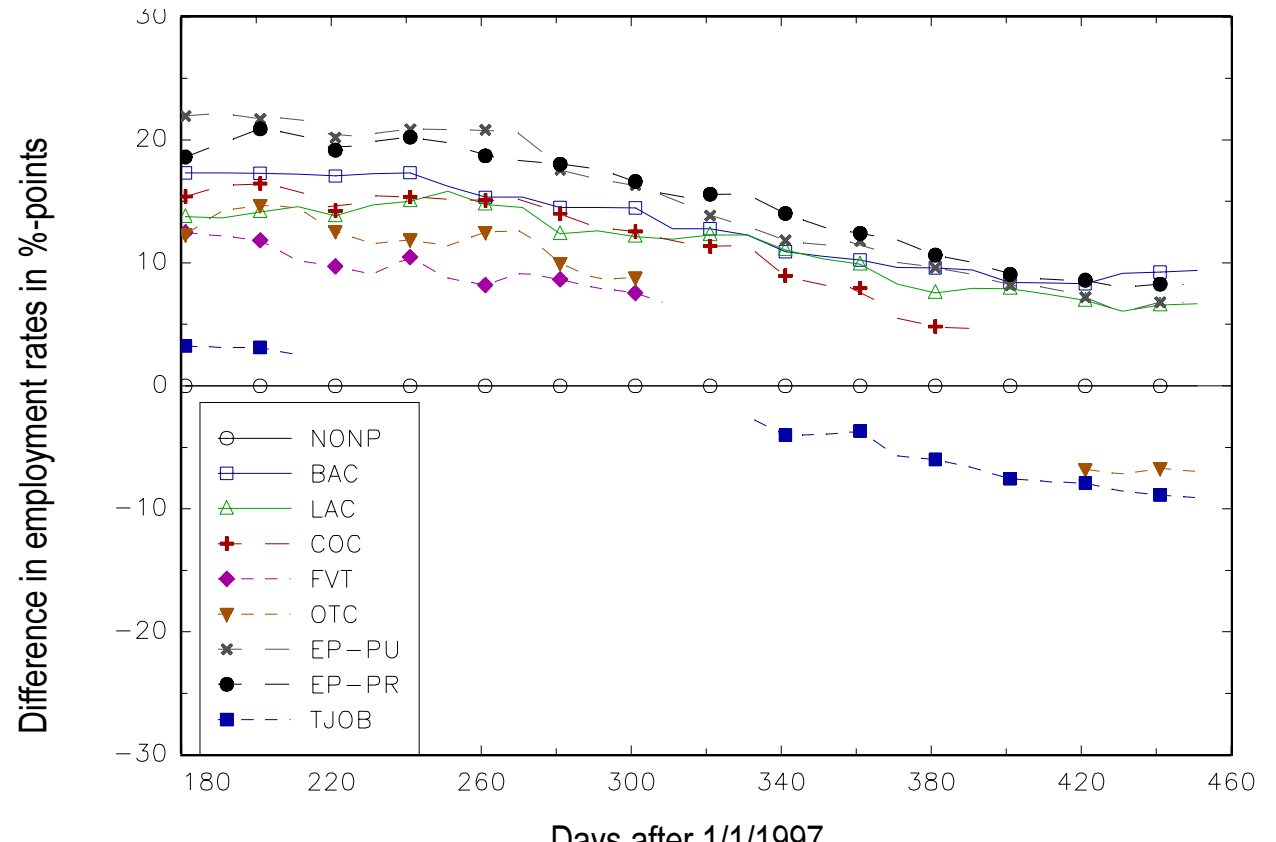

Note: See also note below Figure 8 . Only observations after the start of the programme are used. 
Figure B.10: Subsample of foreigners with permanent permit and Swiss citizens who are full-time unemployed

Figure B.10a: Composite effects for the respective participants

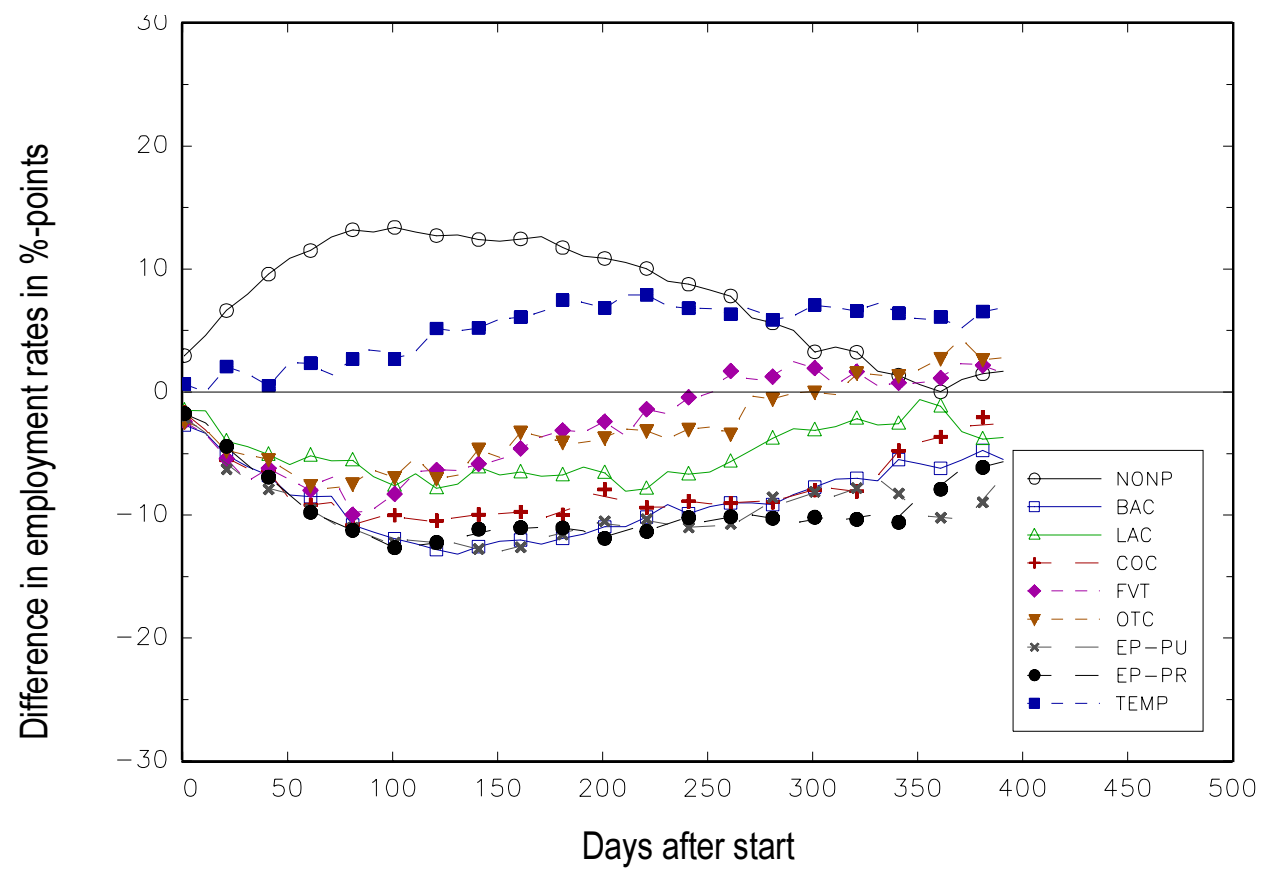

Note: See also note below Figure 8. Only observations after the start of the programme are used.

Figure B.10b: The comparison to nonparticipation for the population

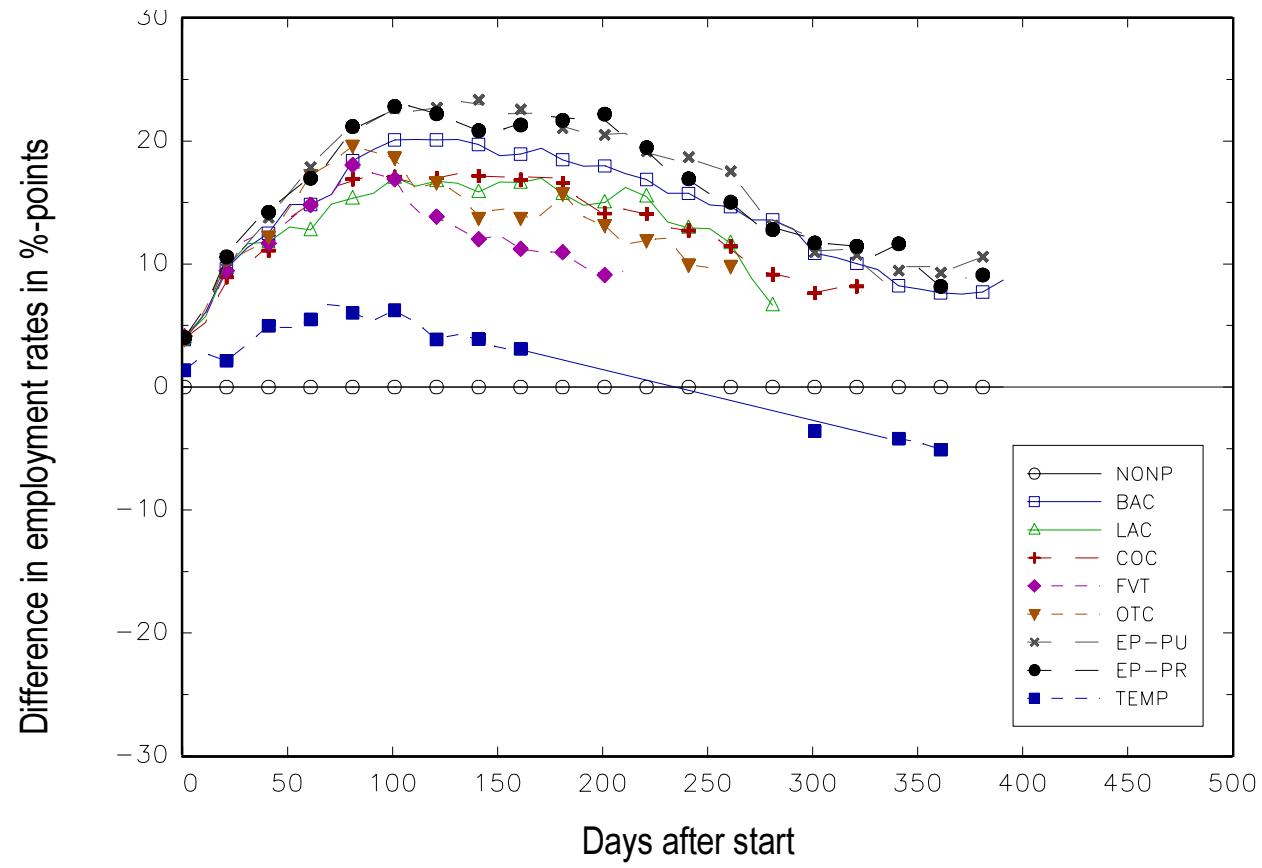

Note: See also note below Figure 8. Only observations after the start of the programme are used. 
Figure B.10c: The effects of LANGUAGE COURSE for the participants in LAC

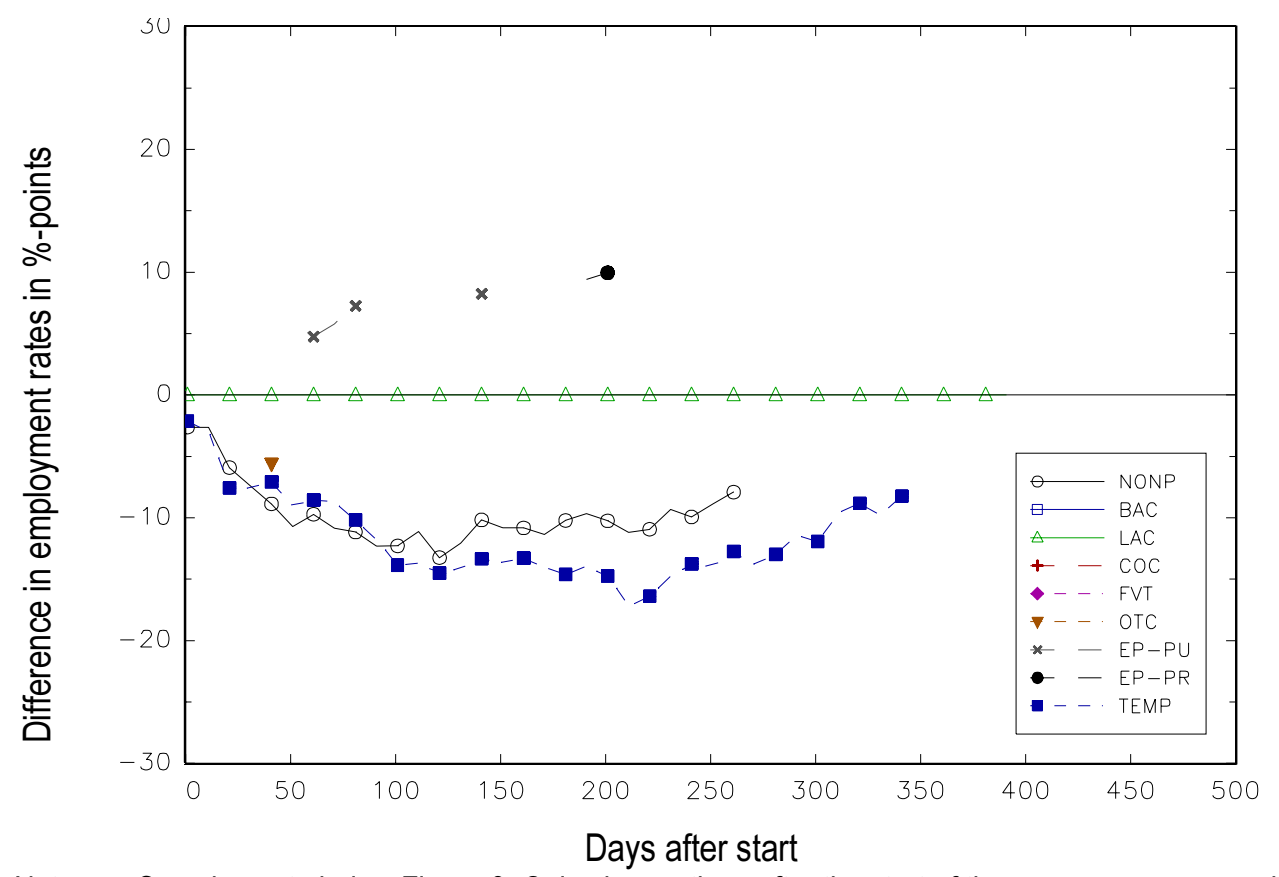

Note: See also note below Figure 8. Only observations after the start of the programme are used.

Figure B.11: Subsample of women who are foreigners with permanent permit or Swiss citizens and full-time unemployed

Figure B.11a: Composite effects for the respective participants

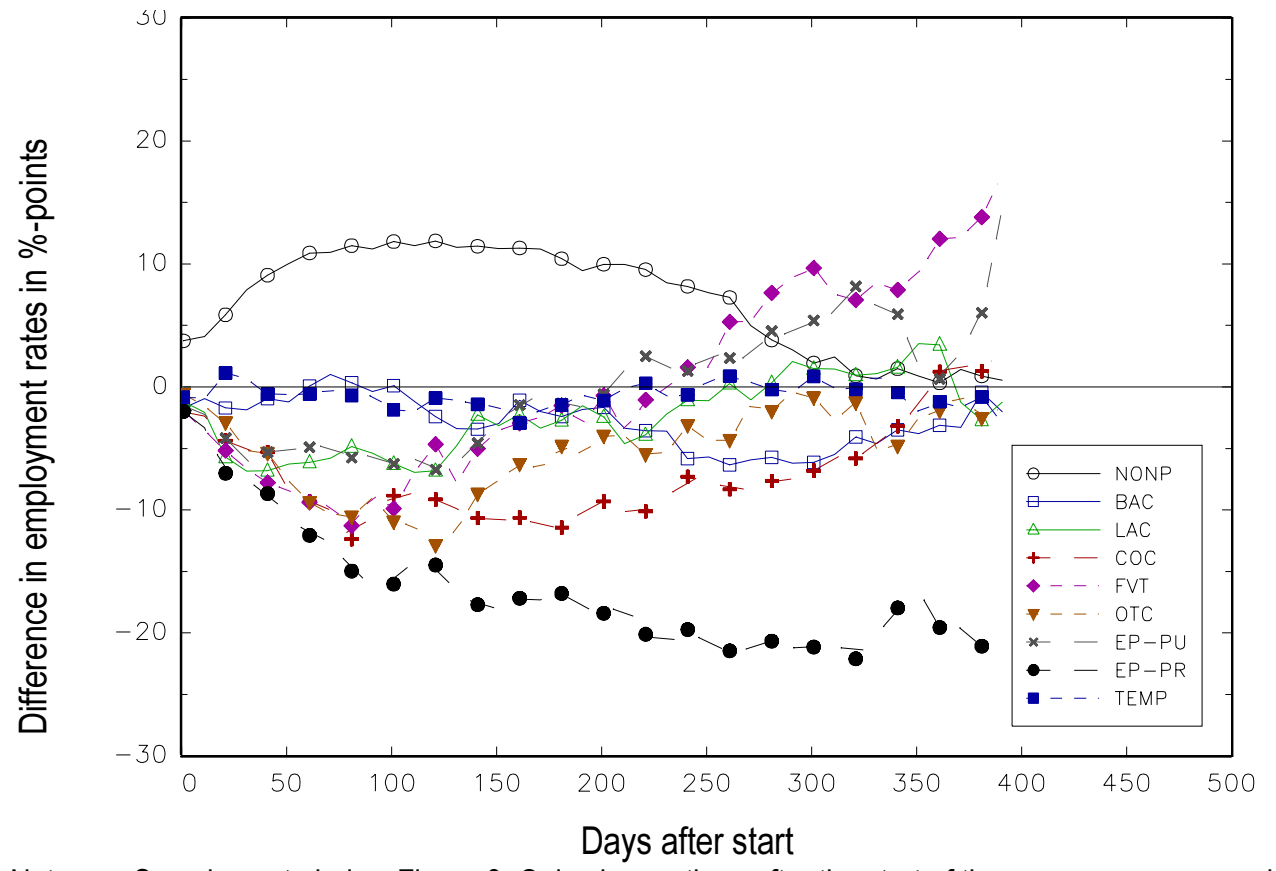

Note: See also note below Figure 8. Only observations after the start of the programme are used. 
Figure B.11b: The comparison to nonparticipation for the population

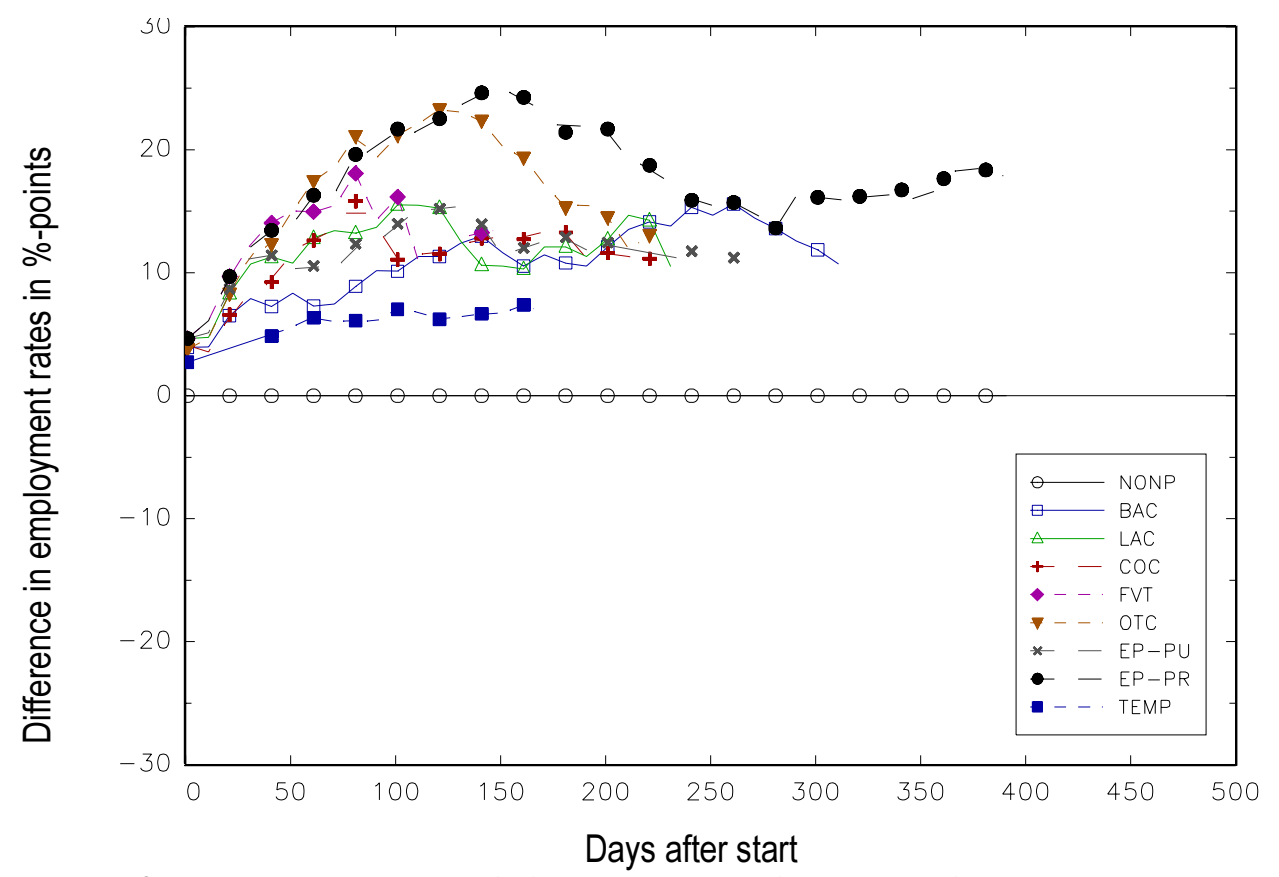

Note: See also note below Figure 8. Only observations after the start of the programme are used. 


\section{IZA Discussion Papers}

No. Author(s)

51

A. Barrett

P. J. O'Connell

52 J. Mayer

R. T. Riphahn

53

J. Hartog

P. T. Pereira

J. A. C. Vieira

54 M. Lofstrom

55

L. Goerke

56

A. Lindbeck

D. J. Snower

57

I. N. Gang

K. F. Zimmermann

58

T. Bauer

K. F. Zimmermann

59

D. J. DeVoretz

S. A. Laryea

60

C. Belzil

J. Hansen

61

R. Winkelmann

62

A. Thalmaier

63

M. Ward

64

M. Ward

65

H. Lehmann

J. Wadsworth

A. Acquisti

66

E. J. Bird

H. Kayser

J. R. Frick

G. G. Wagner
Title

Area

Date

Does Training Generally Work?

5

$8 / 99$

The Returns to In-Company Training

Fertility Assimilation of Immigrants: Evidence

3

$8 / 99$

from Count Data Models

Inter-industry Wage Dispersion in Portugal: high

but falling

$8 / 99$

Labor Market Assimilation and the

$8 / 99$

Self-Employment Decision of Immigrant

Entrepreneurs

Value-added Tax versus Social Security

Contributions

Centralized Bargaining and Reorganized Work:

Are they compatible?

Is Child like Parent?

Educational Attainment and Ethnic Origin

9/99

Occupational Mobility of Ethnic Migrants

$9 / 99$

Canadian Immigration Experience:

Any Lessons for Europe?

Subjective Discount Rates, Intergenerational

Transfers and the Return to Schooling

Immigration: The New Zealand Experience

$10 / 99$

Bestimmungsgründe von Fehlzeiten: Welche

Rolle spielt die Arbeitslosigkeit?

1/2/3 9/99

6

$10 / 99$

Your Everyday, Average Academic

$10 / 99$

Salary and the Gender Salary Gap in the Academic Profession

Grime and Punishment: Job Insecurity and Wage 4

Arrears in the Russian Federation

$10 / 99$

The Immigrant Welfare Effect: Take-Up or

3

$10 / 99$ 

of Wage Differentials Transition Economies

\section{0 \\ J. C. van Ours}

J. Veenman
The Netherlands: Old Emigrants - Young Immigrant Country

Migration, Migrants and Policy in the United Kingdom

Privacy, time consistent optimal labor income taxation and education policy

Female Labour Supply, Flexibility of Working Hours, 1 and Job Mobility in the Netherlands

The Heterogeneity and Cyclical Sensitivity of 1 Unemployment: An Exploration of German Labor Market Flows 

Adversity

91 M. Lechner

Tenures that Shook the World: Worker Turnover in $\quad 4$ Russia, Poland and Britain

Identification and Estimation of Causal Effects of

An Evaluation of Public-Sector-Sponsored

Continuous Vocational Training Programs in East

N. Smith 
107 J. C. van Ours G. Ridder

J. Boone

J. C. van Ours

109 G. J. van den Berg

B. van der Klaauw

110 D. DeVoretz

C. Werner

111 V. Sorm

K. Terrell

L. Bellmann

T. Schank

113 R. Euwals

114 G. Brunello

A. Medio

115 A. Cigno

F. C. Rosati

116

C. Belzil

A. Haas

C. Klose

118 M. A. Shields

M. E. Ward

119 A. Lindbeck

D. J. Snower

120 P. T. Pereira

P. S. Martins

121 J. C. van Ours
Fast Track or Failure: A Study of the Completion

Rates of Graduate Students in Economics

Modeling Financial Incentives to Get Unemployed Back to Work

Combining Micro and Macro Unemployment

3

$1 / 00$

Duration Data

A Theory of Social Forces and Immigrant Second

1

$2 / 00$

Language Acquisition

Sectoral Restructuring and Labor Mobility:

A Comparative Look at the Czech Republic

Innovations, Wages and Demand for

5

$2 / 00$

Heterogeneous Labour: New Evidence from a

Matched Employer-Employee Data-Set

Do Mandatory Pensions Decrease Household

Savings? Evidence for the Netherlands

An Explanation of International Differences in

Education and Workplace Training

Why do Indian Children Work, and is it Bad for

3

$2 / 00$

Them?

Unemployment Insurance and Subsequent Job

3

$2 / 00$

Duration: Job Matching vs. Unobserved

Heterogeneity

IAB Employment Subsample 1975-1995.

Opportunities for Analysis Provided by the

Anonymised Subsample

Improving Nurse Retention in the British National

5

$2 / 00$

Health Service: The Impact of Job Satisfaction on Intentions to Quit

The Division of Labor and the Market for

Organizations

Does Education Reduce Wage Inequality?

5

Quantile Regressions Evidence from Fifteen

European Countries

Do Active Labor Market Policies Help Unemployed Workers to Find and Keep Regular Jobs? 
Rational Poverty or Poor Rationality? The Take-up of Social Assistance Benefits

125 F. Büchel

The Income Portfolio of Immigrants in Germany -

Effects of Ethnic Origin and Assimilation. Or:

J. R. Frick

126 J. Fersterer

R. Winter-Ebmer

Who Gains from Income Re-Distribution?

127 M. Karanassou

D. J. Snower

Smoking, Discount Rates, and Returns to

Education

Characteristics of Unemployment Dynamics: The

Chain Reaction Approach

128 O. Ashenfelter

D. Ashmore

O. Deschênes

Do Unemployment Insurance Recipients Actively

Seek Work? Evidence From Randomized Trials in

Four U.S. States

129 B. R. Chiswick

M. E. Hurst

C. Lucifora

The Employment, Unemployment and Unemployment Compensation Benefits of Immigrants

The Returns to Education in Italy: A New Look at the Evidence

Are Immigrants Favorably Self-Selected? An

134 A. D. Kugler

G. Saint-Paul

135 A. Barrett P. J. O'Connell

136 M. Bräuninger M. Pannenberg

Is There a Wage Premium for Returning Irish

Unemployment and Productivity Growth: An

Empirical Analysis within the Augmented Solow 
141 R. Hujer

M. Wellner

142

J. J. Dolado

F. Felgueroso

J. F. Jimeno

143 P. J. Luke

M. E. Schaffer

144 G. Saint-Paul

145 M.-S. Yun

146 T. K. Bauer

J. P. Haisken-DeNew

147 M. Belot

J. C. van Ours

148 L. Goerke

149 R. Lalive

J. C. van Ours

J. Zweimüller

150 J. DiNardo

K. F. Hallock

J.-St. Pischke

151 M. Ward

152 J. J. Dolado

F. Felgueroso

J. F. Jimeno

153 A. S. Kalwij

M. Gregory

154 M. Gerfin

M. Lechner
The Effects of Public Sector Sponsored Training on

Individual Employment Performance in East

Germany

Explaining Youth Labor Market Problems in Spain: 3

Crowding-Out, Institutions, or Technology Shifts?

Wage Determination in Russia: An Econometric

Investigation

Flexibility vs. Rigidity: Does Spain have the worst of 1 both Worlds?

Decomposition Analysis for a Binary Choice Model 7

$4 / 00$

Employer Learning and the Returns to Schooling

5

Does the Recent Success of Some OECD

Countries in Lowering their Unemployment Rates

Lie in the Clever Design of their Labour Market

Reforms?

Employment Effects of Labour Taxation in an Efficiency Wage Model with Alternative Budget

Constraints and Time Horizons

The Impact of Active Labor Market Programs and

Benefit Entitlement Rules on the Duration of Unemployment

Unions and the Labor Market for Managers

7

Gender, Salary and Promotion in the Academic Profession

The Role of the Minimum Wage in the Welfare 3

State: An Appraisal

5

Overtime Hours in Great Britain over the Period 3

1975-1999: A Panel Data Analysis

Microeconometric Evaluation of the Active Labour 6

Market Policy in Switzerland
$4 / 00$

$5 / 00$

$5 / 00$

$5 / 00$

$5 / 00$ 